\title{
GTTC Future of Ground Testing Meta-Analysis of 20 Documents
}

\author{
Steven C. Dunn ${ }^{\mathrm{a}}$ \\ Jacobs, Hampton, VA, 23681, USA \\ John R. Micol ${ }^{\mathrm{b}}$ \\ NASA Langley Research Center, Hampton, VA, 23681, USA \\ David J. Myren ${ }^{\mathrm{c}}$ \\ Aero Systems Engineering, Inc., Saint Paul, MN, 55107, USA \\ and \\ Roman W. Paryz ${ }^{\mathrm{d}}$ \\ NASA Langley Research Center, Hampton, VA, 23681, USA
}

\begin{abstract}
National research, development, test, and evaluation ground testing capabilities in the United States are at risk. There is a lack of vision and consensus on what is and will be needed, contributing to a significant threat that ground test capabilities may not be able to meet the national security and industrial needs of the future. To support future decisions, the AIAA Ground Testing Technical Committee's (GTTC) "Future of Ground Test" (FoGT) Working Group selected and reviewed 20 "seminal" documents related to the application and direction of ground testing. Each document was reviewed, with the content main points collected and organized into sections in the form of a gap analysis - current state, future state, major challenges/gaps, and recommendations. This paper includes key findings and selected commentary by an editing team.
\end{abstract}

\section{Nomenclature}

$\begin{array}{ll}A A A S & =\text { American Association for the Advancement of Science } \\ C F D & =\text { Computational Fluid Dynamics } \\ C S E & =\text { Computational Science and Engineering } \\ D T \& E & =\text { Development, Test and Evaluation } \\ E F D & =\text { Experimental Fluid Dynamics } \\ \text { FoGT } & =\text { Future of Ground Testing working group } \\ \text { FT } & =\text { Flight Test(ing) } \\ G T & =\text { Ground Test(ing) } \\ G T T C & =\text { Ground Testing Technical Committee } \\ H P C & =\text { High Powered Computing } \\ \text { M\&S } & =\text { Modeling and Simulation } \\ N A S A & =\text { National Aeronautics and Space Administration } \\ \text { NPAT } & =\text { National Partnership for Aeronautical Testing } \\ R D T \& E & =\text { Research, Development, Test and Evaluation } \\ U S A F & =\text { United States Air Force }\end{array}$

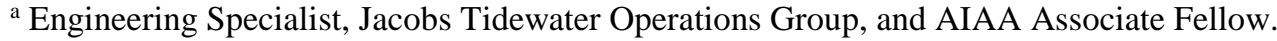

${ }^{\mathrm{b}}$ Research Analyst, Aerothermodynamics Branch, and AIAA Senior Member.

${ }^{c}$ Director, FluiDyne Laboratory, and AIAA Associate Fellow.

${ }^{\mathrm{d}}$ Branch Manager, Subsonic/Transonic Testing, and AIAA Associate Fellow.
} 


\section{Executive Summary}

The AIAA GTTC/FoGT working group has sponsored several interactive sessions on defining issues and approaches associated with experimental ground testing now and going forward in the United States. The consensus of the FoGT working group members is that the current trends in the management of ground testing (GT) capabilities will put the nation at severe risk of not having the capabilities required to develop critical technologies and produce new aerospace products. This relates directly to threats to national defense and the economy.

The working group reviewed and distilled twenty recent 'seminal' documents related to the health and needs of experimental ground testing. The following observations and recommendations/future state comments are the primary takeaways (some are directly from the reviewed documents, the references of which are in the body of the paper):

\section{Observations}

- The US experimental ground test industry is coming out of a long post-cold war downturn. Research is down, maintenance has long lagged and is lagging, and investment in new capabilities is limited.

- The future of ground testing is an integrated, interdependent process with computational methods. It is clear to the authors and the FoGT working group that the future of ground testing is completely intertwined with the development and implementation of computational methods (and vice-versa).

- Uncertainty quantification (UQ) is more robust in experimentation, but computational UQ is improving.

- There is a move toward recognizing and valuing capabilities as tools - sustaining and investing in the experimental and computational tools required to accomplish the research and development for different classes of aerospace products (as opposed to treating capabilities as cost centers).

- The major defects frequently found late in the development cycle for a flight system usually occur at the interface of major subsystems, e.g., aerodynamically induced structural failures. Finding and fixing major defects early, which requires both funding and expertise for experimental and computational testing, results in significantly lower time and cost in the development life cycle and, potentially, gains in product performance.

- Stove-piping has been and remains a significant issue in advancing both the computational and experimental state of the art. Research and development in experimental/measurement/sensing and computational techniques tend to be protected within the originating organization

\section{Recommendations and Future State Needs}

- Saving money on tests is not the right metric. Rather, the proper metric is acquiring enough information to improve quality, resulting in fewer defects and shorter product development times. It should also be noted that improved quality of the research process also positively affects product development.

- Data management/data fusion is not addressed much in this paper, but must be addressed for EFD/CFD integration to proceed and to meet future development needs - possibly the most important element of integration. Rather than generating large amounts of data, sufficient planning for managing the data sets and leveraging computational strengths must be undertaken to develop fused data sets that go beyond what either resource can provide independently.

- Computational modeling will not replace wind tunnel testing in the foreseeable future. Product complexity, flight-envelope expansion, risk aversion, and extensive flight-control systems are the additional drivers for the continued use of the wind tunnel.

- Future workforce will require the right combination of generalists (broad-based skills) and specialists (deeply skilled in specialty areas).

- Capabilities must have sustained investment or services will decline, even as needs (accuracy, data quality, timeliness, more) increase due to product complexity. This includes experimental tools (wind tunnels, propulsion facilities, and measurement and sensing technologies), computational tools (hardware, software, and processes), and data management (acquisition, processing, mining, fusing, organizing, and information output).

- Improved (new and better) test techniques are needed for verification and validation of codes and provide information that may lead to new theories that can be numerically solved in the future.

- Additive manufacturing and rapid mesh/grid generation have the potential to provide rapid responses to new information - shortening the research time required for new designs and concepts.

- Data security was only touched on in this paper but is recognized as a pressing investment requirement, especially as test campaigns become integrated experimentally and computationally, in real time, across geographic locations. 


\section{Introduction}

$\mathrm{T}$ HE American Institute for Aeronautics and Astronautics (AIAA) is the professional society for members of the aerospace industry, providing a collaborative environment that supports teaming to address issues important to the industry. A major organizational element that supports teaming is the collection of 71 technical committees, each addressing a specific discipline area within the aerospace umbrella. The Ground Test Technical Committee (GTTC) was formed in the 1960s to enable sharing of best practices and address common areas of need within the experimental ground testing community.

GTTC leadership has, since the early 2000s, consistently expressed the need for researching and documenting the future direction of ground testing to provide guidance that the members could share with their parent organizations. The GTTC already sponsored a group of original equipment manufacturers (OEMs) that met periodically to produce information on expected future test needs. But this was not enough information to guide test capability owners in determining investment needs or capacity requirements over time. A working group within the GTTC, called "Future of Ground Testing" (FoGT), was formed in 2013 to accomplish the research and report their findings.

Members of the working group were aware of a number of recent papers and reports that assessed various aspects of experimental ground test capabilities. Therefore, the group's initial effort was to collect recent pertinent publications and review these documents to define what the working group should produce that would add value to the existing body of knowledge. What emerged from this review was that the future of ground testing is completely intertwined with the development and availability of computational modeling and simulation (M\&S).

In 2014, a definitive report was published that mapped a way forward for computational M\&S entitled "CFD Vision 2030 Study: A Path to Revolutionary Computational Aerosciences". ${ }^{1}$ This report was fully focused on computational M\&S, recognizing ground testing at interfaces such as being required to validate new codes. Due to the increasingly interdependent nature of experimental and computational testing, this 2014 report allowed the FoGT team to focus on ground testing and directly map the experimental interfaces to computational competencies.

The structure of this ground test report is based on a number of seminal papers produced within the last 15 years by subject matter experts within the aerospace research and development community. The excerpted comments are organized into the form of a gap analysis and sorted into sections with affinity subgroups. The excerpted comments are placed into table form for each section/group and includes selected separate comments from the editing team.

\section{A. Background}

\section{Motivations}

Perhaps the earliest effective ground testing capabilities developed for research were a whirling-arm mechanism and the ballistic pendulum designed by Benjamin Robins in the mid 1700's to study aerodynamic forces on various models at various angles of attack. ${ }^{2}$ It wasn't until the late 1800 's that wind tunnels started to be used to simulate flight effects. The key was improved understanding of the equivalence of air passing over a fixed surface and a surface moving through the air.

As the quest for manned flight in the late 1800's and early 1900's intensified, various applications of models (and some full-scale) through flying tests and ground tests - mostly simple wind tunnels - were used to learn about the aerodynamics of various wing forms and (models of) flying vehicles.

As flying vehicles evolved over the next century, with increasing speed, a wide array of applications and missions, varying geometries, and different combinations of lift and propulsion, ground testing capabilities also evolved and expanded, including such forms as:

- Wind tunnels and propulsion (air breathing and rocket) test facilities with a variety of test techniques and measurement capabilities,

- Vacuum chambers,

- Test tracks,

- Projectile ranges,

- Arc jet facilities,

- Structural/loads testing facilities,

- Environmental testing facilities

- Radar cross section facilities,

- Materials testing, and

- Various labs with specific aero-related research capabilities. 
The scope of this effort is focused on "major" wind tunnels and propulsion facilities in the United States from across government, industry, and academia.

The research, development, test, and evaluation (RDT\&E) process is used in some form to develop every aerospace product, which then can transition to production and use. In simple terms, the product life cycle consists of two major phases: formulation (includes RDT\&E) and implementation. The US Air Force and NASA (National Aeronautics and Space Administration) each use a systems engineering process that begins with requirements flowing from some need and culminates in a system that addresses the need. Along the way, information is acquired that supports risk-based decisions and choices as the system is designed.

An important trade-off during the development process is how much time and money to put into information gathering - it's all about risk management (and cost). More testing (experimentally and computationally) usually drives down risk and is essential, but at what point is the information good enough to allow the design to proceed to the next steps? Testing can be expensive and time-consuming with well-defined costs, leading to a trade decision: spend this time and money now to drive down risk or accept the risk and save cost and time now. The testing campaign is often budget constrained already, so the temptation can be strong to reduce or eliminate tests. Inadequate risk assessment and/or acceptance of higher risks early in the development phase is a major reason for defects migrating across the RDT\&E life cycle, with a problem not being identified until later in the cycle that causes a much more significant impact (increased cost and time) than the savings achieved earlier.

Experimental ground test capabilities exist to provide data and information from basic and applied research through product development and operational support. Over recent decades, computational capabilities have become more robust, replacing or augmenting selected experimental ground and flight testing such that the researcher, developer, or user must choose the appropriate capability to address a need based on risk, cost, schedule, and availability of capabilities. This introduces more complexity into risk management. Selection (with associated costs and times) of the tools themselves affect the quality of the information obtained. The capabilities of the tools, especially computational, are evolving so the selection process will change over time for various applications.

New and updated products are developed by combining new and mature technologies and processes. The key to these new and updated products is the research that generates the new technologies - typically what discriminates the newer product from its predecessors. Without new research, eventually the development of new products would greatly diminish or cease.

Research, as defined by the American Association for the Advancement of Science (AAAS), "is [a] systematic study directed toward more complete scientific knowledge or understanding of the subject studied. The federal government classifies research as either basic or applied according to the objective of the sponsoring agency.

- In basic research, the objective is to gain knowledge or understanding of phenomena without specific applications in mind.

- In applied research, the objective is to gain knowledge or understanding necessary for meeting a specific need." 3

Research is accomplished by industry, government, and academic organizations to develop new things - materials, items, methods, and approaches - based on their needs, purposes, and budgets. A scan of organizational websites revealed many mission support plans and roadmaps that specify areas of research and development (R\&D). Research is an investment in the future that may or may not be targeted at a specific area of need.

Development of a new system, or aerospace product, occurs in response to a defined need or market opportunity. "Development is the systematic use of the knowledge or understanding gained from research for the production of materials, devices, systems, or methods, including design, development, and improvement of prototypes and new processes. It excludes quality control, routine product testing, and production."3

A product life cycle model of the aerospace development process spans from early product concept exploration through development, qualification, and operational support:

- The process results in response by a producer to a market need or opportunity.

- The new system is composed of new and existing technologies.

- Ideally, risk management is robust early in the process - problems are identified and addressed, with solutions integrated into the design.

- The go/no-go decision is based on assessing whether the design meets requirements; estimated costs to produce, operate, and maintain are acceptable; the product can be produced as planned; remaining risks are understood and manageable; and the market/business case remains sound.

- When the process is less than ideal, problems migrate until they are discovered later in the process, often causing delays until the problem can be assessed, a solution developed, and the system redesigned to incorporate the solution (hopefully without "ripple" effect spin-off problems). 


\section{Facility Factors}

Many in the industry classify ground test facilities in two overlapping categories: science and technology (S\&T) facilities used for research and development, test, and evaluation (DT\&E) facilities used for developing products with a focus on production. It really comes down to deliverable capabilities at a particular facility related to test techniques, data quality and repeatability, process efficiency, cost, availability, and customer service. Thus, a customer needing experimental test services must identify facilities with the necessary capabilities and use the other qualifying factors as trade-offs to determine where to run a test.

It should also be noted that the test capabilities themselves, including test and measurement techniques and tools, are also subject to the R\&D process. Very often, new products require new/better/different information from current testing capabilities, typically due to new technologies, greater precision, or required integration with computational results. Thus, improved forms of measurement and testing are regularly developed, moving from labs to S\&T facilities for development and verification, then to either specific facilities for unique applications or across multiple facilities for broad-based applications.

National investment in the tools to accomplish RDT\&E - the facilities - has been trending down over recent decades. ${ }^{4}$ Since the end of the Cold War, many government- and private-owned aerodynamic and propulsion ground test facilities have been closed, greatly reducing capacities and creating some significant deficiencies in capability. Multiple reasons have been identified for these closures: local budget problems, agency budget problems, belief that computers have replaced experimental capabilities, old facilities that require recapitalization and/or increased maintenance, cross-organization challenges, and politics. These are all legitimate reasons to some degree, but the result is that national capabilities are being lost. The nation lacks a national vision and consensus on what is and will be needed - in great contrast to post WWII - contributing to a significant threat that national ground test capabilities may not be able to meet the national security and industrial needs of the future. This is the key reason for the effort that went into this paper.

It is inevitable that computational tools will continue to be developed and will grow more capable and efficient as codes are improved and computer speeds and processing capabilities grow. The nature of ground testing has changed, and will continue to change, as test campaigns become a more interdependent mix of experimental and computational work. Software development likely will continue to require, for many more decades, various forms of experimental validation. There are still several significant computational capability challenges to be worked, as noted in the CFD (computational fluid dynamics) Vision 2030 report. It is therefore expected that there will be a continued need for experimental ground testing for the foreseeable future.

The FoGT working group has sponsored several interactive sessions on defining issues and approaches associated with experimental ground testing now and going forward in the United States. The consensus of the FoGT working group members is that the current trends in the management of ground testing (GT) capabilities will put the nation at severe risk of not having the capabilities required to develop critical technologies and produce new aerospace products. This relates directly to threats to national defense and the economy.

The goal of this paper is to synthesize the findings and opinions of a recent cross-section of significant national reports and papers by industry subject matter experts. It is hoped that this paper will provide a national picture of the current state of national ground test capabilities, the trajectory of those capabilities if left unchecked, and where subject matter experts would like these capabilities to go.

\section{B. Approach}

In discussions on how to accomplish this effort, many in the group could point to several publications that already addressed ground testing issues, needs, recommendations, and projected future states. It was decided that pertinent publications - formal reports, conference papers, and key briefings from the last five to ten years - would be collected and the top 15 to 20 publications would be selected for review and used to generate this paper.

The team met at a conference and selected the top 20 from about 60 posted publications. The selection criteria were a mix of objective and subjective ranking, based on the status of the author, the source and quality of data and information, the scope of the content, and the applicability of the content in terms of describing the environmental factors driving the industry, the state of capabilities, and future plans.

The documents selected and used in this paper are as follows:

1. Kraft, E. M., "Integrating Computational Science and Engineering with Testing to Re-Engineer the Aeronautical Development Process", 48th AIAA Aerospace Sciences Meeting Including the New Horizons Forum and Aerospace Exposition. January 2010, AIAA 2010-139. ${ }^{5}$

2. Committee to Assess NASA's Aeronautics Flight Research Capabilities, National Research Council of the National Academies, "Recapturing NASA's Aeronautics Flight Research Capabilities", The National Academies Press, 2012. ${ }^{6}$ 
3. Committee on the Assessment of NASA's Laboratory Capabilities, National Research Council of the National Academies, "Capabilities for the Future: An Assessment of NASA Laboratories for Basic Research", The National Academies Press, 2010.7

4. Kallimani, J., Ohlandt, C., Anton, P. and Osburg, J, "Future Test Needs of U.S. National Wind Tunnels for NASA's Aeronautics Test Program: An Approach for Mapping Ground Test Facility Usage Projections into Capability Projections", 49th AIAA Aerospace Sciences Meeting including the New Horizons Forum and Aerospace Exposition. January 2011, AIAA 2011-1069. ${ }^{8}$

5. Malik, M., and Bushnell, D., "Role of Computational Fluid Dynamics and Wind Tunnels in Aeronautics R and D”, NASA/TP-2012-217602, November 2012.9

6. Slotnik, J., Khodadoust, A., Alonso, J., Darmofal, D., Gropp, W., Lurie, E., and Mavriplis, D., “CFD Vision 2030 Study: A Path to Revolutionary Computational Aerosciences", NASA/CR-2014-218178, March 2014. ${ }^{1}$

7. European Commission, "Flightpath 2050, Europe's Vision for Aviation", Luxembourg: Publications Office of the European Union, 2011. ${ }^{10}$

8. Kraft, E. M., “After 40 Years Why Hasn't the Computer Replaced the Wind Tunnel?”, ITEA Journal, 2010, 31: 329-346. ${ }^{11}$

9a. Anton, P. S, Johnson, D. J., Block, M., Brown, M., Drezner, J., Dryden, J., Gritton, E. C., Hamilton, T., Hogan, T., Mesic, R., Peetz, D., Raman, R., Steinberg, P., Strong, J., and Trimble, W., "Wind Tunnel and Propulsion Test Facilities", Rand Corporation, 2004. ${ }^{12}$

9b. Anton, P. S, Raman, R., Osburg, J., and Kallimani, J. G., “An Update of the Nation's Long-Term Strategic Needs for NASA's Aeronautics Test Facilities", Rand Corporation, 2009. ${ }^{13}$

10. The National Science and Technology Council, "National Aeronautics Research and Development Plan", Office of Science and Technology Policy, Washington, D.C., February, 2010. ${ }^{14}$

11. The National Science and Technology Council, "National Aeronautics Research, Development, Test, and Evaluation (RDT\&E) Infrastructure Plan”, Office of Science and Technology Policy, Washington, D.C., January, 2011..$^{15}$

12. Advisory Council for Aviation Research and Innovation in Europe, "Realising Europe's Vision for Aviation, Strategic Research and Innovation Agenda, Volume 1", September, 2012. ${ }^{16}$

13. Kraft, E. M.., "HPCMP CREATETM-AV and the Air Force Digital Thread", 53rd AIAA Aerospace Sciences Meeting. January 2015, AIAA 2015-0042. ${ }^{17}$

14. Fetterhoff, T., Kraft, E., Laster, M., and Cockson, W., "High-Speed/Hypersonic Test and Evaluation Infrastructure Capabilities Study", 14th AIAA/AHI Space Planes and Hypersonic Systems and Technologies Conference. November 2006, AIAA 2006-8043. ${ }^{18}$

15. Melanson, M., "An Assessment of the Increase in Wind Tunnel Testing Requirements for Airvehicle Development Over the last 50 Years", 46th AIAA Aerospace Sciences Meeting and Exhibit. January 2008, AIAA 2008-830. ${ }^{19}$

16. Best, J., Kraft, E., and Huber, A., "Revitalizing the Technical Excellence of the Workforce at the Arnold Engineering Development Center (AEDC) and Beyond", 2008 U.S. Air Force T\&E Days. February 2008, AIAA $2008-1611 .^{20}$

17. Skelley, M., Langham, T., and Peters, W., "Integrated Test and Evaluation for the 21 st Century", USAF Developmental Test and Evaluation Summit. November, 2004, AIAA 2004-6873. ${ }^{21}$

18. Melanson, M., Chang, M., and Baker II, W., "Wind Tunnel Testing's Future: A Vision of the Next Generation of Wind Tunnel Test Requirements and Facilities", 48th AIAA Aerospace Sciences Meeting Including the New Horizons Forum and Aerospace Exposition. January 2010, AIAA 2010-142. ${ }^{22}$

19. Dunn, S. C., "Direction and Integration of EFD and CFD, a Summary of Two Panel Sessions," 54th AIAA Aerospace Sciences Meeting, January 2016, AIAA 2016-0896. ${ }^{23}$

A document review and editing process was developed and implemented, as follows:

1. Review each document and collect (directly excerpt) the primary points and findings. Keep each comment exactly in the words of the author(s) and retain the original source via citation for each.

Please note that the document references use the above one through nineteen numbers (not where they fall out in references at the end of the document). 
Table 1 Organizing Information Excerpts into Sections and Groups.

\begin{tabular}{|c|c|c|}
\hline \multirow{6}{*}{ Sections } & Context & $\begin{array}{l}\text { Provides the background for the current } \\
\text { state of ground testing. }\end{array}$ \\
\hline & GT Current State & $\begin{array}{l}\text { Information pertaining to the } \\
\text { current/recent state of ground testing. }\end{array}$ \\
\hline & Computational Current/Future States & $\begin{array}{l}\text { Information focused on CFD for now, in } \\
\text { the future, and gaps/challenges. }\end{array}$ \\
\hline & GT Future State & $\begin{array}{l}\text { Future projections of the state of ground } \\
\text { testing; various or unspecified timing. }\end{array}$ \\
\hline & Gaps/Challenges & $\begin{array}{l}\text { Gaps and challenges GT, integrated } \\
\text { GT/CFD and some CFD will be facing. }\end{array}$ \\
\hline & Recommendations & $\begin{array}{l}\text { Recommendations, including the } \\
\text { integration of ground testing and CFD, } \\
\text { from now to the future state. }\end{array}$ \\
\hline \multirow{9}{*}{$\begin{array}{c}\text { Groups } \\
\text { (Within Each } \\
\text { Section) }\end{array}$} & Approach to Testing & $\begin{array}{l}\text { Test types, techniques, measurements, } \\
\text { and instrumentation }\end{array}$ \\
\hline & Integration of GT/CFD & $\begin{array}{l}\text { Integration experimental testing and } \\
\text { computational modeling }\end{array}$ \\
\hline & Efficiency/Cycle Time Reduction & $\begin{array}{l}\text { Efficiency improvements and cycle time } \\
\text { reduction measures }\end{array}$ \\
\hline & Capability Sustainment/Maintenance & $\begin{array}{l}\text { Sustaining existing capabilities, including } \\
\text { maintenance and operations/maintenance } \\
\text { integration }\end{array}$ \\
\hline & Capability Investment/I\&M & $\begin{array}{l}\text { Investment in existing or new facilities to } \\
\text { produce new/advanced capabilities }\end{array}$ \\
\hline & Workforce/Staffing & $\begin{array}{l}\text { All pertaining to workforce, staffing, } \\
\text { people output/needs/initiatives }\end{array}$ \\
\hline & Strategic Perspective & $\begin{array}{l}\text { Management and leadership - how and } \\
\text { why decisions were and might be made. }\end{array}$ \\
\hline & Programmatic Drivers & $\begin{array}{l}\text { Costs, funding, workloads, competition, } \\
\text { government policies, industry needs. }\end{array}$ \\
\hline & Systems Integration/Interfacing & $\begin{array}{l}\text { The RDT\&E process, integrating product } \\
\text { elements, defect management, } \\
\text { organizational interfacing. }\end{array}$ \\
\hline
\end{tabular}

2. Organize each comment into information groups, shown in Table 1. Some comments are included, as applicable, in multiple section/group categories.

a. Sections are the main categories for the gap analysis.

b. As the team sorted comments, a set of topical affinity groups emerged, as shown in Table 1.

3. Accomplish knowledge work (by the cited editors/authors of this paper) on each set of grouped comments:

a. Summarize key points and takeaways,

b. Add any needed commentary (context and voice of the FoGT), and

c. Identify any actionable recommendations.

The goal in collecting and organizing all this information was to capture the salient points each author was making and then to combine these points to describe a definitive range of current state with associated gaps and recommendations - expected to be relatively converged - and the range of possible future states with associated gaps and recommendations. The range of publications from different perspectives and different levels of effort/depth were expected to provide a (comprehensive / cohesive) mosaic of the current and future states. 
The focus of this paper is experimental aeronautics ground testing and the papers chosen by the FoGT working group were ground testing related. There are overlapping disciplines that this effort only touches on that are crucial to the future RDT\&E needs of the nation, including the following:

- Aeronautics computational development and application, including integration with experimental techniques. There is information in this paper on integration, but only to the extent the authors addressed in their publications.

- Experimental measurement and instrumentation capabilities development and application. This is foundational support discipline area for experimental ground testing and is barely addressed in this paper.

- Data collection, management, and use are also barely addressed. As experimental and computational capabilities continue to develop, more data will be generated and must be integrated from multiple sources to produce actionable information.

- Experimental flight testing provides the actual flow physics environment to validate development on the ground, but is typically expensive and capabilities and capacities are limited. This area was also only touched on in the study papers.

The editors recognize that this process was subjective, since the team selected the excerpts deemed to best represent the views and position of the study reference authors. The goal was to capture those views in summarized form and not to push or bias toward some preconceived viewpoint. The editors did include comments, noted separately in the tables, related to changes since a study document comment was published or to make editorial comments. While the excerpts are taken directly from the study reference documents, their abbreviated form could allow a different interpretation (without associated context) than the author(s) intended. The editing team strove to prevent different interpretations and takes full responsibility for any presentation flaws.

Since the excerpts often use abbreviations explained earlier in their respective documents, each unique abbreviation is spelled out at first occurrence in this paper. This paper also tends to use a few abbreviations interchangeably:

- CFD and CSE (computational science and engineering)

- EFD (experimental fluid dynamics) and GT (ground testing) and/or FT (flight testing)

- $\mathrm{CFD}$ is generalized for a range of computational methods.

\section{Document Takeaways}

The excerpted comments were organized first into sections and then further into the topical affinity groups noted in Table 1. They were formatted as tables organized by section, group and original references. Since the documents were produced over a period of several years to address a variety of needs, the editing team reviewed each table and added comments to selected excerpts. The team then selected the main points/takeaways from each section/group, though not each section/group produced takeaways.

The editors see much value in the specific excerpted comments, but the tables are several pages long and not all readers will want to comb through the tables to find the takeaways. Therefore, the main points/takeaways are presented in this section and the full tables are included as Appendix 1. In these lists of points/takeaways, please note:

- Verbiage taken directly from the documents is in quotes; source references are cited.

- Statements with no quotes indicate inputs from the authors of this paper.

\section{A. Context}

\section{Integration of GT/CFD}

- In the context of CFD simulations, Code Calibration refers to, in most cases, the agreement between computational and experimental results. Calibration arises from the uncertainty in modeling complex physical processes. ${ }^{24}$ Verification is the process of determining that a model (a representation of a physical system or process intended to enhance the ability to understand, predict, or control its behavior) and its implementation, accurately represent the developer's conceptual description of the model and the solution to the model. ${ }^{24}$ Verification Assessment determines if the programming and computational implementation of the conceptual model is correct. Another attribute, is the examination of the mathematics in the models through comparison to exact analytical results. Examination of programming for computer programming errors is another aspect of verification assessment. Validation per the AIAA guideline is the process of determining the degree to which a model is an accurate representation of the real world from the perspective of the intended uses of the 
model. ${ }^{24}$ Validation Assessment is determining if the computational simulation agrees with physical reality. It examines the science in the models through comparison to experimental results.

- Uncertainty is defined as "A potential deficiency in any phase or activity of the modeling process that is due to the lack of knowledge" and Error is defined as "A recognizable deficiency in any phase or activity of modeling and simulation that is not due to the lack of knowledge." ${ }^{24}$ The overall goal is to demonstrate the accuracy of CFD codes in order to use them with confidence for performing numerical aerodynamic simulation and furthermore, that the simulation might provide credible results for decision making in design.

- "The challenge today is how best to combine the use of CFD with wind-tunnel testing to improve the prediction of aerodynamic flight loads while reducing the development cycle time."

- “. . . research efforts must establish to what degree these CFD tools can be trusted to replace wind-tunnel experiments for the purposes of predicting aerodynamic characteristics ..."

- "While high-performance computing (HPC) hardware is expected to continue to advance at a rapid rate, note that this advance in HPC hardware will not automatically translate into advances in predictive CFD, or more generally, into the multidisciplinary design optimization (MDO) capabilities that are required for the efficient design of aerospace systems."

- CSE/CFD will advance when it is clearly advantageous to do so for particular application areas - results (output quality and quantity), cost, timeliness, risk

- "If CSE could actually eliminate the use of wind tunnels in system development, the net gain to the acquisition program would be fractions of a percentage in cost savings. On the other hand, reducing the overall cycle time by merging CSE and wind tunnel testing could reduce total development cycle time by months to years, resulting in billions of dollars of savings." 11

- "The best way to minimize the impact of rework on cycle time is early discovery of defects. This will entail improvements in design methodologies employed by aircraft companies coupled with improvements in wind tunnel testing and modeling techniques."11

\section{Capability Sustainment/Maintenance}

- “... the cost of maintaining required wind tunnel infrastructure, let alone developing new test capabilities, has been a very real and difficult challenge. Aging facilities, diminishing number of development programs, ineffective business models, diminishing national investment in aeronautical research and development, all combine to challenge those responsible for developing and maintaining this required capability." 19

- "The third period - the current period of decline - started in the early 1990s with the end of the First Gulf War. A "peace dividend" was declared, producing a 40-percent budget reduction across the DoD, including AEDC (Arnold Engineering Development Center). A major shift in philosophy overtook the aerospace industry manifested as a shift from the early technical emphasis on "further, higher, faster" to a financial emphasis on "faster, better, cheaper." (Internal Reference) It has become a very competitive environment, with reduced budgets that have brought bottom-line-driven business people to top management positions." 20

\section{Capability Investment/Improvement and Modernization (I\&M)}

- Hypersonic investment over recent decades has lagged, greatly impacting development of new products.

- "Development of a new test capability, in today's world, would require approximately a twenty-year effort." 19 Difficult to define requirements for some date 10-to-20 years out and even harder to justify the expenditure when so many things are needed now. So, capabilities mostly remain either static or received incremental (not transformative) improvement.

\section{Workforce/Staffing}

- "A study was performed at the Massachusetts Institute of Technology (Internal Reference) to understand whether the application of large-scale computer simulation to the design process would offset the inexperience of aircraft designers. ... The key findings from the study were as follows:

○ There is a strong linkage between experience and performance;

- 70s-era design efforts outperformed 90s-era in weight management;

- Test phase is an important downstream indicator of design performance - test personnel understood design flaws through exposure to recurring problems;

- Modern design tools are graphically compelling, but reduced experimental experience led to deficiencies." 
- Since 2000, NASA aeronautics testing per person declined - trade for maintaining existing expertise against investing in the future.

- NASA aeronautics researchers are a significant national asset for their contributions to test customer research and development.

\section{$\underline{\text { Strategic Perspective }}$}

- "One of the major problems facing NASA's aeronautics program is that it has been directed to pursue a large number of goals, but it clearly lacks the resources to accomplish more than a few of them."

- Treating capabilities as cost centers results in behavior that exacerbates the financial situation. Typically, a local or agency decision (in their stovepipe) to try to recover costs with reduced testing, often results in added risk to the product. Pinching local pennies can cause potentially big dollar (and time) impacts to product development due to defect migration.

- Aeronautics is crucial to the U.S. economy and jobs. Circa 2010: "Aviation contributes an estimated \$741 billion to the U.S. economy or roughly 5.6 percent of the nation's gross domestic product. Over 11 million jobs with $\$ 369$ billion in wages are estimated to be associated with the aviation industry. The aerospace products and parts sector is the largest U.S. manufacturing exporter ..."14

- "The system development cycle time from the Milestone B (MS-B) decision to design and build the system until the Initial Operational Capability (IOC) has dramatically increased over the last several decades until the time from MS-B to IOC for the Joint Strike Fighter is well in excess of 200 months." 17

- The history of improving GT throughput has not been nearly enough to offset the effects from complexity. A more revolutionary approach integrating EFD and CFD is indicated but progressing slowly.

\section{Programmatic Drivers}

- "As a percentage of the NASA budget, aeronautics research has declined from $\sim 7$ percent in 2000 to $\sim 3$ percent in 2010." NASA Aeronautics was 3.34\% of the total NASA budget in FY2017. ${ }^{25}$

- "NASA spends approximately $1.5 \%$ of CRV (current replacement value) on maintenance annually but the current industry guideline is $2 \%$ to $4 \%$ of CRV. Maintenance budgets would need to double to reach industry guidelines." 7

- Research takes, typically, 10-20 years before it is manifested in a product. Looking at the huge reduction in NASA aeronautics research over the 2000s, consider the foundational and applied research that is missing going into the next ten years - there has to be a significant impact.

- Defaulting to CFD for research or development because the tangible costs of experimental ground testing are deemed high is a false choice at the system level. There is a cost for CFD that is often ignored. And the researcher or developer having access to the right tool(s) should result in a better product.

- "In search of lower costs and modern wind tunnel technology, U.S. customers typically conduct 25 percent of their wind tunnel development at European facilities."13

\section{Systems Integration/Interfacing}

- "The major defects frequently found late in the development cycle for a flight system usually occur at the interface of major subsystems, e.g., aerodynamically induced structural failures." 5

$\circ \quad$ ". . . a structural flaw found very late in the development cycle of a fighter aircraft can easily drive a billion dollar plus bill when the time and cost to redesign, rebuild, retest, and modify production tooling are accounted for. On average, ten structural flaws of varying importance are discovered during developmental flight testing." 20

- Finding and fixing major defects early, which requires funding and expertise for experimental and computational testing, results in significantly lower time and cost in the development life cycle - and, potentially, gains in product performance.

- "At the same time computer systems have advanced, so has the complexity of aeronautical systems. Over the last 30 years, expanded flight envelopes, super-maneuverability, super-cruise, low observables, and advances in materials technology have made it more challenging to model the physics of military flight systems." 


\section{B. GT Current State}

\section{Approach to Testing}

- "Currently, insufficient in-house technical expertise and analysis tools are available to support hypersonic flight-test planning and engineering analysis activities."18

\section{Integration of GT/CFD}

- "CFD validation against experimental data is crucial, and this is essentially why, for example, automobile companies have continued to build new wind tunnels, particularly for aeroacoustic considerations." 9

- Experimental GT provides more than aero data in short amounts of time - it can be "used to predict not only the performance, but also the operability, reliability, and maintainability of an aeronautical system."

- One element of cycle time reduction is the time it takes to design, fabricate, and verify wind tunnel models rapid prototyping and additive machining can significantly reduce fabrication time.

\section{Workforce/Staffing}

- ". . . there has been a significant decline in the experience base of aeronautical designers and developers . . . the experience base for post-WWII engineers was approximately 6-12 new design aircraft per career. . . . In contrast, an aerospace engineer starting his career today may experience only one, maybe two new system designs during his or her career." 5

- "It is recognized that the paraprofessional and craft workforces contribute immensely to the technical reputation of AEDC and require technical excellence to conduct their jobs." 20

- "The education system is becoming much more multi-disciplinary. Need young people with the ability to see the big picture. Meaningful work is important. Should not just have young people tracking down drawings, etc. The work must interest them." 23

Programmatic Drivers

- "The trend in number of programs (per decade) is a telling sign of the increased complexity and cost associated with aircraft programs." 19

- Cost is king (at least to some). Not so long ago, technical excellence was first, often followed closely by schedule. Cost was important and managed, but not primary. It's always a trade between these three.

\section{Computational Current/Future States}

\section{Integration of GT/CFD}

- The current tools are mostly stand-alone and are not necessarily standardized across the ranges. The vision would be to have an automated suite of tools ...

- The question is not can CFD give a great answer for one or two test cases, but can the CFD "processes" give good answers for a range of cases when run by a competent engineer?

- At the current state of technology, CFD engineers may spend much more time just setting up a computer job. Large database requirements (hundreds of thousands of individual flight conditions) may be obtained less expensively via wind-tunnel testing for a long time into the future.

- Uncertainty management already is a requirement for experiments and needs to be for CFD.

\section{Capability Investment/I\&M}

- "Research in grid generation is generally under-valued, but it is important to note that grid generation is not a solved problem."9

- "Because the solution cost of high-order methods varies strongly with grid size, robust grid adaptation is needed to optimally distribute the grid and minimize the overall grid size." 9

- Data management is one of the areas not addressed much in this paper, but must be addressed for EFD/CFD integration to proceed and to meet future development needs. More and more data is being generated; what is needed and how it will be managed must be defined before each test (experimental, computational, or both) campaign. Otherwise, unnecessary time and money will be spent and there is significant risk that needed data will not have been acquired. 
Workforce/Staffing

- Acquiring, processing, managing/organizing data, then putting it into a useful form (with quality verified) in a timely manner for the next step in a test is crucial. This role is critical to integrating EFD and CFD data.

○ "Need 'data reductionists' ..."23

\section{Programmatic Drivers}

- Costing drives behavior that drive results. CFD has costs that are often managed differently than for experimental testing - experimental testing tends to have well defined costs while CFD may be inexpensive or "free" to the end user. This can drive bias toward using computational over experimental tools, which may or may not be the best tool selection for the researcher or developer.

\section{GT Future State}

\section{Approach to Testing}

- "Advances in data mining and data merging software as an integral part of the facility data systems to enable rapid analyses of the variances along response surfaces."

- "Virtual presence, networking, and connectivity to achieve a fully integrated developmental and operational test (DT/OT) approach in an interoperable environment."

- "With a vision of the future in mind, key capabilities and characteristics for a new (or upgraded) capability should include:

- Multi-mission capability,

Moderate test sections size,

Advanced data mining capability,

Excellent test section optical access,

Ease of access and installation,

Highly automated testing,

Highly connected facility,

Ability to create model configurations on-site,

Energy efficiency, and

Expert staff." 19

\section{Integration of GT/CFD}

- "Computational modeling will not replace wind tunnel testing in the foreseeable future." "Product complexity, flight-envelope expansion, risk aversion, and extensive flight-control systems are the additional drivers for the continued use of the wind tunnel." 19

- "Except for flight-certification issues, CFD will soon be ready to replace wind tunnels for the attached-flow cruise conditions." ${ }^{\text {C }}$ Cost per point must also considered.

- It's about best value risk management based on the state of the particular system in development. The goal is to meet technical, cost, and schedule development goals. This means finding and fixing major and most minor defects early. So, design a test campaign (EFD and CFD) that best accomplishes risk management at the system level.

Capability Sustainment/Maintenance

- "Maintenance and improvement of key test assets is a vital component of enabling future test capabilities." ${ }^{22}$

\section{Workforce/Staffing}

- Vision: "Predicting accurately the future wind tunnel test requirements, both in terms of capability and capacity, is difficult; but historical data trends indicate a strong need to maintain significant wind tunnel test expertise and capability." 19

\section{Strategic Perspective}

- Research is the foundation for the future.

- Future capability needs must be based on future vehicle development needs.

- "The value of wind tunnels for weapon systems should be measured by the quality of flight systems we can produce rather than cost." 23 


\section{E. Gaps/Challenges}

\section{Approach to Testing}

- "An area where scaling effects are not well understood and CSE may have the potential for producing new insights is simulation of military tactical aircraft at high-angle maneuvering conditions." 5

- ". . . there is not a capability to propulsion mode transition testing at supersonic and hypersonic Mach numbers." ${ }^{18}$ (Note that CUBRC can duplicate high enthalpy chemistry effects.)

- "At Mach numbers greater than 12, the gases begin to ionize. Dissociation and recombination can continue to occur in the flow boundary layer resulting in significant effects on the vehicle heating. Existing ground-test facilities can provide partial simulation." 18 (Note that CUBRC can duplicate high enthalpy chemistry effects.)

- "The large engine test facilities are limited to Mach 3.2, yet turbine engine R\&D programs predict future engine performance to Mach 4 and above." ${ }^{18}$ Note that NASA Glenn PSL-4 facility is rated to Mach 4.0. ${ }^{26}$

\section{Integration of GT/CFD}

- "CFD data can be used to determine initial structural sizing, to support wing trade studies, and to help scale the wind-tunnel database to flight conditions. However, CFD is not yet able to deliver the required degree of accuracy (low single-digit percentages over a wide range of conditions) and the throughput that is necessary to replace extensive wind-tunnel testing."

- "The well-recognized challenges for CFD technology include:

- Aeroelastic distortion

○ Boundary conditions (e.g., wind-tunnel walls, stings, and in-flight boundary conditions for higher fidelity simulations)

- Turbulence modeling (e.g., formulations, variable constants, gross shortfalls in capability)

- Predictions for drag (which are far less accurate than those for lift)

○ "Untrustworthy" results near the outer portions of the flight envelope

- Boundary-layer transition location(s)/locus, subsequent "paths to turbulence"

- Discretization errors

- Mismatches in (macro and micro) geometry, computation-to-experiment and application."

- "While low speed (e.g., takeoff/landing) is a problem for CFD, supersonic speed is even more difficult because of the strong shock-boundary-layer interactions, and hypersonic speed is probably the most difficult of all because of the critical roles of boundary-layer transition, heat transfer, and chemical reaction."

- "Perhaps the single, most critical area in CFD simulation capability that will remain a pacing item by 2030 in the analysis and design of aerospace systems is the ability to adequately predict viscous turbulent flows with possible boundary layer transition and flow separation present."1

- “... some test facilities cannot replicate the turbulence found in nature as well." ${ }^{23}$

\section{Efficiency/Cycle Time Reduction}

- "Defects discovered late during the development process not only increase cycle time but also can impact manufacturing costs if significant tooling and production have already occurred."11

- "Improvements are needed in wind tunnels:

$\circ$ Efficiency

$\circ \quad$ Rapid prototyping

- New measurement techniques

- Unsteady flow measurements

- $\quad$ Skin-friction measurements

- Non-intrusive: Pressure sensitive paint and particle image velocimetry." ${ }^{23}$ Global surface and offbody measurements (such as pressure sensitive paint and particle image velocimetry).

\section{Capability Sustainment/Maintenance}

- "Low-use facilities can be closed for long periods, but cost savings may be lower than expected and capabilities will degrade quickly." 13

- “. . . those tunnel facilities that are seen to have low utilization will be in danger of closure, further degrading the nation's capability to maintain our global leadership in aerospace." 22 Be careful of conflating usage with value. 


\section{Capability Investment/I\&M}

- A designed campaign of unit experiments is necessary for advancement in computational capabilities.

○ "In order to assess the role of modeling errors and develop better physical models, a need exists for detailed unit experiments that involve simple configurations for which grid generation and the associated discretization errors are not the issue." $"$

- “. . . data storage media will not support future HS/H (high speed/hypersonic) system requirements, and data distribution requirements for future hypersonic missions will exceed the capability of current distribution networks." 18

- Need for CSE research to solve challenges like unsteady separation, boundary-layer transition.

- "Several drawbacks exist in today's sensor systems. First, they are generally intrusive. Second, they are less reliable than the hardware that is being monitored. Third, most need manual calibration. Fourth, they are unable to detect when the output is degraded or has failed. Finally, they cannot detect off-nominal readings caused by the effects of failures in other parts of the system." 18

- Future workforce will require the right combination of generalists (broad-based skills) and specialists (deeply skilled in specialty areas).

- Significant test capability gaps existing in wind tunnels and propulsion facilities - relying on long-existing facilities plus improvements over time; examples noted include hypersonic speed and size limitations and propulsion turbine engine to scramjet transition test limitations.

- "Improvements are needed in wind tunnels:

○ Efficiency

○ Rapid prototyping

- New measurement techniques

- Unsteady flow measurement

- Skin-friction measurements

- Non-intrusive: Pressure sensitive paint and particle image velocimetry." ${ }^{23}$ Global surface and offbody measurements (such as pressure sensitive paint and particle image velocimetry).

\section{$\underline{\text { Strategic Perspective }}$}

- “... military systems which provide the most technically challenging environment for large-scale computing. Military systems fly over larger speed ranges and operating envelopes, have more intense integration issues such as low observable, weapons integration, buried inlet/engine configurations, etc. and have a much more challenging multiorganizational environment in which to implement CSE." 5

- "Lack of explicit collaboration among turbulence researchers."1

- "Comprehensive interagency management policies for aeronautics infrastructure do not yet exist." ${ }^{15}$ Local priorities and budgets are primary (stovepipes).

- "The challenge for developing an integrated roadmap for HS/H engineering development and test and evaluation (T\&E) capability requirements is to identify the capability requirements for each discipline."18

- "The aerospace industry (both government and private sector) must adapt to a strategy of maintaining and operating key and critical wind tunnels as essential assets which insures the nation's leadership in the aerospace field." 22

\section{Programmatic Drivers}

- “... if funding continues to decline, NASA may not be able to claim aeronautics technology leadership from an international and in some areas even a national perspective." 7

- "Despite numerous attempts at acquisition reform, the number of acquisition programs behind schedule and over costs continues to escalate." 17

- Near-term budgets have driven much of the decision-making in recent decades. Facility usage is a key measure of value to the system in current terms. Suggest that capabilities be valued based on information generated for development and risk reduction of specific product classes, both current and projected. This becomes more of a strategic decision perspective.

\section{F. Recommendations}

Approach to Testing

- "A large static rig facility is needed for testing full-scale prototype rotorcraft systems." 15

- "Basic data analysis and reporting should be considered an inherent cost of testing by the customer."20 
- "We must analyze the wind tunnel in its environment with all interferences in order to understand it." 23 The wind tunnel environment must be analyzed with all its initial and boundary conditions (e.g., inflow, walls, and interference effects) characterized. This is also critical for GT/CFD integration.

\section{$\underline{\text { Integration of GT/CFD }}$}

- “... a vision needs to be created for innovative ways to bring CSE and testing together to have the maximum impact on the effectiveness of the development process." A major question is who will have the authority and the resources to lead an effort with maximum results as its goal? Does the US have the will to do this?

- "To successfully integrate CSE and testing will require advances not only in high-performance computing but in intellectual capital and process management as well." 5

- "The proper national debate that needs to be held is not CSE versus test facilities. The aeronautics community would be better served putting their energy into creating a vision for how CSE can be integrated with physical testing processes to increase the effectiveness of both during the development of systems. .."5

- ". . . the national discussion at this stage should not be about shutting down test facilities in the near future because of HPC but about how to use HPC to increase the effectiveness of the aeronautical development process by reducing the design/acquisition cycle time." 9

- "NASA should lead efforts to develop and execute integrated experimental testing and computational validation campaigns." 1

- Could forensic investigations reveal root sources of some defects that could guide improved early test and computational campaigns?

- "The aeronautics community would be better served putting their energy into creating a vision for how CSE can be integrated with physical testing processes to increase the effectiveness of both during the development of systems. Effectiveness in the context of this article means the ability to reduce the overall cycle time for development while minimizing the need for rework of late defect discoveries."11

\section{Efficiency/Cycle Time Reduction}

- "Whether experimental or CFD, the concern is how long it takes to produce information for flight prediction; need to produce knowledge, not data. Whether experimental or CFD, the developer must know his customer's accuracy requirements which are becoming more stringent in many ways; e.g., cruise and pitching moment considerations." ${ }^{23}$

\section{Capability Sustainment/Maintenance}

- Capabilities must have sustained investment or services will decline, even as needs (accuracy, data quality, timeliness, more) increase due to product complexity.

\section{Capability Investment/I\&M}

- "The best way to minimize the impact of rework on cycle time is early discovery of defects. This will entail improvements in design methodologies employed by aircraft companies coupled with improvements in wind tunnel testing and modeling techniques. ... Also, feedback loops from discrepancies found in flight testing back to ground testing and back to design methodology need to be institutionalized to make further improvements." 12

- "An urgent need exists to reinvigorate research in computational science and engineering at NASA, as well as to provide access to the state-of-the-art computer hardware to NASA scientists."

- "The most readily identifiable major investment need from our survey of users is associated with the hypersonic vehicle programs. Serious research challenges in hypersonic air-breathing propulsion (e.g., vitiated/non-vitiated issues in hypersonic propulsion facilities) may require new facilities and test approaches for breakthroughs to occur." 12

- "A large static rig facility is needed for testing full-scale prototype rotorcraft systems." 15

- "Maintenance and improvement of key test assets is a vital component of enabling future test capabilities." 22

- "A large-scale (16-ft square test section) (AEDC/16S) supersonic wind tunnel testing capability is needed for the development of expanded missile defense vehicles."23

\section{Workforce/Staffing}

- "Efforts should be undertaken by the Air Force T\&E Enterprise to share information on its technical excellence initiatives with the larger, national T\&E and acquisition workforces." 20 
- "Need 'data reductionists' and to design software to handle data." 23

\section{Strategic Perspective}

- "The proper national debate that needs to be held is not CSE versus test facilities. The aeronautics community would be better served putting their energy into creating a vision for how CSE can be integrated with physical testing processes to increase the effectiveness of both during the development of systems." 5

- "NASA should lead efforts to develop and execute integrated experimental testing and computational validation campaigns." If not NASA, who?

- "There is also the potential for sharing some of the same modeling methodologies between the structural analysts and the propulsion system designers." 11

- "NASA should work with the DoD to analyze the viability of a national reliance test facility plan, since this could affect the determination of the future minimum set of facilities NASA must continue to support." 12 Is the National Partnership for Aeronautical Testing (NPAT) enough?

- "The most critical issue is for NASA headquarters leadership to develop a specific and clearly understood aeronautics test technology vision and plan."12

- "Interdependencies and overlapping research goals among research agencies in the Federal Government create a need for closer cooperation and coordination of processes and facilities planning. Some of the barriers to improved cooperation can be lowered by leadership from the Federal departments and agencies that own critical infrastructure, the NSTC and the Office of Management and Budget (OMB)."15

- The nation has lost a lot of test infrastructure over the last 25 years; often due to local situations. Was what was needed for the future retained? Suggest a formal view on what is needed and take actions to support and invest in the future.

- "The value of wind tunnels for weapon systems should be measured by the quality of flight systems we can produce rather than cost." ${ }^{\prime 2}$ Treat capabilities as tools, with their value based on contributions to product.

\section{Programmatic Drivers}

- "NASA aeronautics should aggressively pursue collaboration with the Department of Defense, the Federal Aviation Administration, the U.S. aerospace industry, and international aeronautics research agencies. NASA should adopt management practices to facilitate effective collaboration and treat external organizations as customers and partners."

- "NASA aeronautics should become the nation's repository of flight research data and flight test results and should make these archival data readily accessible to key stakeholders - the engineers and scientists in industry, academia, and other government agencies." 6

- "NASA should lead efforts to develop and execute integrated experimental testing and computational validation campaigns."

- "The most critical issue is for NASA headquarters leadership to develop a specific and clearly understood aeronautics test technology vision and plan, to continue to support the development of plans to very selectively consolidate and broadly modernize existing test facilities, and to proscribe common management and accounting directions for NASA's WT/PT (wind tunnel/propulsion tunnel) facilities." 12

- "Critical shortfalls:

Ground Test Facilities

- Subsonic Acoustic Measurement and Low Turbulence Flow Test Facilities

Hypersonic Materials Test Facilities

- Hypersonic Engine (Scramjet) Development Propulsion Test Facilities

- Turbine Engine Icing Test Facilities

- Turbine Engine Combustion Facilities

- Full-Scale Rotorcraft Test Facilities

Flight Test Facilities

○ Transport Category Flight Test Aircraft

- Hypersonic Test Ranges

- Airborne Icing Capability

High-End Computational Facilities

○ High-End Computing Capacity"15 


\section{Systems Integration/Interfacing}

- “. . . feedback loops from discrepancies found inflight testing back to ground testing and back to design methodology need to be institutionalized to make further improvements." ${ }^{5}$ If common defect roots could be identified, significant improvement to cycle time reduction could result.

- NASA aeronautics should aggressively pursue collaboration with the Department of Defense, the Federal Aviation Administration, the U.S. aerospace industry, and international aeronautics research agencies. NASA should adopt management practices to facilitate effective collaboration and treat external organizations as customers and partners.

- NASA aeronautics should become the nation's repository of flight research data and flight test results and should make these archival data readily accessible to key stakeholders - the engineers and scientists in industry, academia, and other government agencies.

\section{Summary}

Many members of the GTTC (and many people outside the GTTC) have long been concerned that critical RDT\&E ground testing capabilities are at risk. Many, perhaps most, capability sustainment and investment decisions are made parochially. Compounding the situation is the often-parallel parochial sustainment and development of aeronautics computational techniques and tools. The nation lacks a consensus on what is and will be needed, contributing to a significant threat that ground test capabilities may not be able to meet the national security and industrial needs of the future. This paper is intended to provide information to decision-makers responsible for the support, development, and integration of these critical experimental and computational tools.

This summary of information was taken from twenty documents related to aeronautical experimental ground testing. Each document was reviewed, and key points and takeaway comments were directly excerpted. These were then organized en masse into sections structured as a gap analysis, then further into subject affinity groups. These were then placed into tables, with editorial comments added to select comments - included as the section tables in the Appendix. The authors then distilled these down into the primary points presented in the preceding Chapter II (Document Takeaways).

A number of overall observations and recommendations/future state needs emerged from Chapter II, which are summarized below:

\section{Observations}

- The US experimental ground test industry is coming out of a long post-cold war downturn. Research is down, maintenance has long lagged and is lagging, and investment in new capabilities is limited.

- Hypersonic investment over recent decades has greatly lagged with boom-bust cycles, greatly impacting development of new products.

- Staffing has become challenging in a number of ways, especially for hypersonics. Investment in technical excellence staff waned along with other sustainment and investment funding.

- Significant test capability gaps existing in wind tunnels and propulsion facilities - relying on longexisting facilities plus improvements over time; examples noted include hypersonic speed and size limitations and propulsion turbine engine to scramjet transition test limitations.

- The future of ground testing is an integrated, interdependent process with computational methods. It is clear to the authors and the FoGT working group that the future of ground testing is completely intertwined with the development and implementation of computational methods (and vice-versa).

$\circ$ It is very challenging to become expert in both EFD and CFD. This impedes the integration of the two. Two distinctly different cultures exist - a challenge that must be overcome to effectively integrate them.

- Uncertainty quantification (UQ) is more robust in experimentation, but computational UQ is improving.

- There is a move toward recognizing and valuing capabilities as tools - sustaining and investing in the experimental and computational tools required to accomplish the research and development for different classes of aerospace products (as opposed to treating capabilities as cost centers).

$\circ$ Investing in improved test and measurement techniques on the basis of their return-on-investment (ROI) is likely a false flag - increasing complexity largely offsets improvements. Investing in improved quality and information turnaround that support life cycle efficiency can be a significant positive.

- Be careful of conflating usage with value.

- CSE/CFD will advance when it is clearly advantageous to do so for particular application areas - results (output quality and quantity), cost, timeliness, and risk. 
- "The major defects frequently found late in the development cycle for a flight system usually occur at the interface of major subsystems, e.g., aerodynamically induced structural failures." ${ }^{5}$ Finding and fixing major defects early, which requires both funding and expertise for experimental and computational testing, results in significantly lower time and cost in the development life cycle and, potentially, gains in product performance.

- Experimental GT provides more than aero data in short amounts of time - it can be "used to predict not only the performance, but also the operability, reliability, and maintainability of an aeronautical system."

- "It is recognized that the paraprofessional and craft workforces contribute immensely to the technical reputation of AEDC and require technical excellence to conduct their jobs. ${ }^{\prime 20}$ This is true across the RDT\&E workforce.

- Stove-piping has been and remains a significant issue in advancing both the computational and experimental state of the art. Research and development in experimental/measurement/sensing and computational techniques tend to be protected within the originating organization

○ "Lack of explicit collaboration among turbulence researchers."

- "Comprehensive interagency management policies for aeronautics infrastructure do not yet exist." 15 Local priorities and budgets (stovepipes) persist.

- Another form of stove-piping is organizational and individual hand-off of product development in the DT\&E process. Early cost cutting (resulting from reduced testing) can be rewarded, but could result in increased cost and schedule delays downstream due to defect migration.

Recommendations and Future State Needs

- Saving money on tests is not the right metric. Rather, the proper metric is acquiring enough information to improve quality, resulting in fewer defects and shorter product development times. It should also be noted that improved quality of the research process also positively affects product development.

- "If CSE could actually eliminate the use of wind tunnels in system development, the net gain to the acquisition program would be fractions of a percentage in cost savings. On the other hand reducing the overall cycle time by merging CSE and wind tunnel testing could reduce total development cycle time by months to years, resulting in billions of dollars of savings." 11

- Data management/data fusion is not addressed much in this paper, but must be addressed for EFD/CFD integration to proceed and to meet future development needs - possibly the most important element of integration. Rather than generating large amounts of data, sufficient planning for managing the data sets and leveraging computational strengths must be undertaken to develop fused data sets that go beyond what either resource can provide independently.

- "Computational modeling will not replace wind tunnel testing in the foreseeable future." "Product complexity, flight-envelope expansion, risk aversion, and extensive flight-control systems are the additional drivers for the continued use of the wind tunnel." 19

- A designed campaign of unit experiments is necessary for advancement in computational capabilities.

- Future workforce will require the right combination of generalists (broad-based skills) and specialists (deeply skilled in specialty areas).

○ "Need "data reductionists" and to design software to handle data." 23

- "The proper national debate that needs to be held is not CSE versus test facilities. The aeronautics community would be better served putting their energy into creating a vision for how CSE can be integrated with physical testing processes to increase the effectiveness of both during the development of systems. . ."

- Capabilities must have sustained investment or services will decline, even as needs (accuracy, data quality, timeliness, more) increase due to product complexity. This includes experimental tools (wind tunnels, propulsion facilities, and measurement and sensing technologies), computational tools (hardware, software, and processes), and data management (acquisition, processing, mining, fusing, organizing, and information output).

$\circ$ Saving money on tool sustainment/investment and reducing testing in a trade with research and product quality directly relates to defect migration across the RDT\&E life cycle. Early scope trades must be made against the overall product system costs, timing, and performance.

- "The value of wind tunnels for weapon systems should be measured by the quality of flight systems we can produce rather than cost." ${ }^{13}$ Treat capabilities as tools with their value based on contributions to research and product quality. 
- Moving forward with GT/CFD integration as well as improvements in each discipline tends to be at the pace of individual organizations - stove-piping from a combination of intellectual property protections, security limitations, and parochialisms (we paid for this and we're not giving it away) limit shared developments.

○ "NASA should lead efforts to develop and execute integrated experimental testing and computational validation campaigns." If not NASA, who?

- "NASA aeronautics should aggressively pursue collaboration with the Department of Defense, the Federal Aviation Administration, the U.S. aerospace industry, and international aeronautics research agencies." 6

- "NASA aeronautics should become the nation's repository of flight research data and flight test results and should make these archival data readily accessible to key stakeholders - the engineers and scientists in industry, academia, and other government agencies." Again, if not NASA, who?

- Improved (new and better) test techniques are needed for verification and validation of codes and provide information that may lead to new theories that can be numerically solved in the future.

- Additive manufacturing and rapid mesh/grid generation have the potential to provide rapid responses to new information - shortening the research time required for new designs and concepts.

- Data security was only touched on in this paper but is recognized as a pressing investment requirement, especially as test campaigns become integrated experimentally and computationally, in real time, across geographic locations.

The authors and FOGT working group team are encouraged with significant recent progress in workforce investment, increasing test workload, advancing computational technologies, and the recognition that GT is a resource to be maintained at a strategic level along with the need for continued CFD development. NASA's new funding model and collaboration through both NPAT and AIAA continue towards charting a path forward that uses GT and CFD efficiently and effectively to support aerospace product development and acquisition. It is hoped that this paper, through consolidation of primary points and key recommendations from industry subject matter experts, will provide ideas and guidance to industry leaders as they position capabilities, organizations, and processes to meet aerospace RDT\&E needs for the next 30+ years. 


\section{Appendix}

The following tables contain the grouped comments that were identified as key points/takeaways from the twenty source documents. The comments are organized into sections and groups within sections. They are sorted within each group by the source document from which each comment was obtained. Additionally, the editors added comments to selected material based on current conditions and an RDT\&E system perspective.

\section{A. Context}

\begin{tabular}{|c|c|c|}
\hline Group & $\begin{array}{l}\text { Doc } \\
\text { Ref \# }\end{array}$ & Excerpted Material and Comments \\
\hline Approach & 1 & $\begin{array}{l}\text { To a large part, the added speed and storage of the hardware has been consumed by increasing the fidelity } \\
\text { and complexity of the class of problems in hand. This increase in fidelity is required to improve the accuracy } \\
\text { of the solutions to put them on par with wind tunnel and flight testing data. }\end{array}$ \\
\hline Approach & 5 & $\begin{array}{l}\text { It is important to note that verification can only be conducted for idealized situations (linear partial } \\
\text { differential equations, smooth solutions, uniform grids, and so on) which are never present in realistic } \\
\text { simulations. Further, most theoretical properties are in terms of rates, such as the rate of mesh } \\
\text { convergence or of iterative convergence, and there are few absolutes that can be "verified" in such a } \\
\text { manner. }\end{array}$ \\
\hline Approach & 11 & $\begin{array}{l}\text { Critical shortfalls: } \\
\text { Ground Test Facilities } \\
\text { - } \quad \text { Subsonic Acoustic Measurement and Low Turbulence Flow Test Facilities } \\
\text { - } \quad \text { Hypersonic Materials Test Facilities } \\
\text { - } \quad \text { Hypersonic Engine (Scramjet) Development Propulsion Test Facilities } \\
\text { - } \quad \text { Turbine Engine Icing Test Facilities } \\
\text { - } \quad \text { Turbine Engine Combustion Facilities } \\
\text { - } \quad \text { Full-Scale Rotorcraft Test Facilities } \\
\text { Flight Test Facilities } \\
\text { - } \quad \text { Transport Category Flight Test Aircraft } \\
\text { - Hypersonic Test Ranges } \\
\text { - } \quad \text { Airborne Icing Capability } \\
\text { High-End Computational Facilities } \\
-\quad \text { High-End Computing Capacity } \\
\end{array}$ \\
\hline \multirow[t]{2}{*}{$\begin{array}{l}\text { GT/CFD } \\
\text { Integration }\end{array}$} & \multirow[t]{2}{*}{1} & $\begin{array}{l}\text { To further advance CSE (computational science and engineering) into the development process will } \\
\text { require a clear advantage to the program manager relative to better quality of data, lower costs, reduced } \\
\text { risk, or reduced cycle time. }\end{array}$ \\
\hline & & $\begin{array}{l}\text { Editor: Note that CSE and CFD (computational fluid dynamics) are terms taken directly from the } \\
\text { reference documents. They are essentially used interchangeably in this paper to represent aero } \\
\text { computational modeling and simulation. }\end{array}$ \\
\hline $\begin{array}{l}\text { GT/CFD } \\
\text { Integration }\end{array}$ & 1 & $\begin{array}{l}\text { The list of physics modeling challenges that inhibit the robust application of CSE is legend. The classical } \\
\text { problems are turbulence modeling, boundary-layer transition, and flow separation. }\end{array}$ \\
\hline $\begin{array}{l}\text { GT/CFD } \\
\text { Integration }\end{array}$ & 5 & $\begin{array}{l}\text { The challenge today is how best to combine the use of CFD with wind-tunnel testing to improve the } \\
\text { prediction of aerodynamic flight loads while reducing the development cycle time. }\end{array}$ \\
\hline \multirow[t]{2}{*}{$\begin{array}{l}\text { GT/CFD } \\
\text { Integration }\end{array}$} & \multirow[t]{2}{*}{5} & $\begin{array}{l}\text { The impact of CFD is that much less commercial transport business is available to the wind-tunnel } \\
\text { facilities. The picture is considerably different from a military perspective, where configurations tend to be } \\
\text { different and include many compromises to the aerodynamics for multidisciplinary reasons. }\end{array}$ \\
\hline & & $\begin{array}{l}\text { Editor: Work is migrating from experimental to computational as computational improves and becomes } \\
\text { more viable - commercial transport development is one example. }\end{array}$ \\
\hline $\begin{array}{l}\text { GT/CFD } \\
\text { Integration }\end{array}$ & 5 & $\begin{array}{l}\text { The substantial role of CFD in configuration screening and refinement, particularly at cruise conditions } \\
\text { for transport aircraft, was recognized as contributing to a reduction of about } 50 \text { percent in the number of } \\
\text { required testing hours for such applications. }\end{array}$ \\
\hline $\begin{array}{l}\text { GT/CFD } \\
\text { Integration }\end{array}$ & 5 & $\begin{array}{l}\text { The use of CFD tools by aerospace engineers will require the determination of how well these } \\
\text { computational tools predict important design characteristics of the target aerospace vehicles. In other } \\
\text { words, research efforts must establish to what degree these CFD tools can be trusted to replace wind- } \\
\text { tunnel experiments for the purposes of predicting aerodynamic characteristics ... }\end{array}$ \\
\hline $\begin{array}{l}\text { GT/CFD } \\
\text { Integration }\end{array}$ & 5 & $\begin{array}{l}\text { While high-performance computing (HPC) hardware is expected to continue to advance at a rapid rate, } \\
\text { note that this advance in HPC hardware will not automatically translate into advances in predictive CFD, } \\
\text { or more generally, into the multidisciplinary design optimization (MDO) capabilities that are required for } \\
\text { the efficient design of aerospace systems. }\end{array}$ \\
\hline \multirow[t]{2}{*}{$\begin{array}{l}\text { GT/CFD } \\
\text { Integration }\end{array}$} & \multirow[t]{2}{*}{5} & $\begin{array}{l}\text { Engineering program managers will willingly adopt a CFD-based design process, depending on how well } \\
\text { CFD improves the process in four general areas: Quality (accuracy) ..., Schedule (time) ..., Cost ..., } \\
\text { Risk... }\end{array}$ \\
\hline & & $\begin{array}{l}\text { Editor: CSE/CFD will advance when it is clearly advantageous to do so for particular application areas - } \\
\text { results (output quality and quantity), cost, timeliness, risk }\end{array}$ \\
\hline
\end{tabular}




\begin{tabular}{|c|c|c|}
\hline Group & $\begin{array}{l}\text { Doc } \\
\text { Ref \# }\end{array}$ & Excerpted Material and Comments \\
\hline \multirow[t]{2}{*}{$\begin{array}{l}\text { GT/CFD } \\
\text { Integration }\end{array}$} & \multirow[t]{2}{*}{8} & $\begin{array}{l}\text { At hypersonic conditions, additional physical phenomena such as real gas chemistry, conjugate heat } \\
\text { transfer, wall catalicity, shock/shock interactions, etc., create significant problems for CSE. Compounding } \\
\text { the physical modeling issue is the dearth of qualified experiments and test facilities to explore the } \\
\text { physics and provide sufficient high quality data to validate and verify the models. }\end{array}$ \\
\hline & & Editor: Outside of transonic cruise, CSE/CFD has challenges. \\
\hline \multirow[t]{2}{*}{$\begin{array}{l}\text { GT/CFD } \\
\text { Integration }\end{array}$} & \multirow[t]{2}{*}{8} & $\begin{array}{l}\text { If CSE could actually eliminate the use of wind tunnels in system development, the net gain to the } \\
\text { acquisition program would be fractions of a percentage in cost savings. On the other hand reducing the } \\
\text { overall cycle time by merging CSE and wind tunnel testing could reduce total development cycle time by } \\
\text { months to years, resulting in billions of dollars of savings. }\end{array}$ \\
\hline & & $\begin{array}{l}\text { Editor: Integrating CFD/EFD (experimental fluid dynamics) gains much more from cycle time reduction } \\
\text { than saving from reduced experimental testing. } \\
\text { Additional clarification: the term EFD is used interchangeably with experimental testing throughout these } \\
\text { tables. }\end{array}$ \\
\hline \multirow[t]{2}{*}{$\begin{array}{l}\text { GT/CFD } \\
\text { Integration }\end{array}$} & \multirow[t]{2}{*}{8} & $\begin{array}{l}\text { Turbulence modeling may be one of those intractable engineering problems that cannot be solved with } \\
\text { higher performance computing. }\end{array}$ \\
\hline & & $\begin{array}{l}\text { Editor: There are significant computational physics modeling challenges that will limit CSE/CFD } \\
\text { application. }\end{array}$ \\
\hline \multirow[t]{2}{*}{$\begin{array}{l}\text { GT/CFD } \\
\text { Integration }\end{array}$} & \multirow[t]{2}{*}{8} & $\begin{array}{l}\text { Typical applications include pretest planning to ensure optimization of the test facility and } \\
\text { instrumentation; support to real-time data analysis and decision making; analysis of potential wind tunnel } \\
\text { effects such as support or wall interference; extrapolation of wind tunnel data to flight conditions; support } \\
\text { to flight testing, particularly weapon separation; and support to operational flight issues that occur after a } \\
\text { system has been developed. }\end{array}$ \\
\hline & & $\begin{array}{l}\text { Editor: CSE facilitates looking at incremental effects; iterating with experimental findings to better } \\
\text { understand flow characteristics }\end{array}$ \\
\hline \multirow[t]{2}{*}{$\begin{array}{l}\text { GT/CFD } \\
\text { Integration }\end{array}$} & \multirow[t]{2}{*}{17} & $\begin{array}{l}\text { The development of a successful aircraft or weapon system requires the assurance of airframe- } \\
\text { propulsion system compatibility early in the development cycle to prevent costly engine instabilities or } \\
\text { performance deficiencies in fielded systems. . . Computational tools are under development to bridge the } \\
\text { gap between the inlet testing and engine testing. Computational support will provide understanding of the } \\
\text { flow field, as well as of the cause and effect relationship between inlet and engine. }\end{array}$ \\
\hline & & $\begin{array}{l}\text { Editor: CFD is used and being developed to complement experimental testing at the system (propulsion, } \\
\text { airframe) by identifying additional system interactions typically not identified until flight testing }\end{array}$ \\
\hline \multirow[t]{2}{*}{$\begin{array}{l}\text { GT/CFD } \\
\text { Integration }\end{array}$} & \multirow[t]{2}{*}{17} & $\begin{array}{l}\text { Under the general umbrella of aeromechanics, store integration, aerodynamic performance, inlet } \\
\text { performance, and jet effects have become intensive areas of growth at AEDC. Over the past two } \\
\text { decades aircraft store integration has become the most intensive area of growth for computations and } \\
\text { evaluation. This has come about primarily through the marrying of the wind tunnel with modeling and } \\
\text { simulation (M\&S) using the IT\&E methodology. }\end{array}$ \\
\hline & & $\begin{array}{l}\text { Editor: Can AEDC's experience in merging CSE and GT tools be used as a framework for future efforts } \\
\text { to determine the most effective combination? }\end{array}$ \\
\hline \multirow[t]{2}{*}{ Efficiency } & \multirow[t]{2}{*}{5} & $\begin{array}{l}\text { While high-performance computing (HPC) hardware is expected to continue to advance at a rapid rate, } \\
\text { note that this advance in HPC hardware will not automatically translate into advances in predictive CFD, } \\
\text { or more generally, into the multidisciplinary design optimization (MDO) capabilities that are required for } \\
\text { the efficient design of aerospace systems. }\end{array}$ \\
\hline & & $\begin{array}{l}\text { Editor: Gains in computational efficiency advances have been offset by increasing modeling complexity } \\
\text { fidelity. Also, a trend in wind tunnel testing - better models, more component testing - complexity offsets } \\
\text { efficiency gains. }\end{array}$ \\
\hline Efficiency & 5 & $\begin{array}{l}\text { Engineering program managers will willingly adopt a CFD-based design process, depending on how well } \\
\text { CFD improves the process in four general areas: Quality (accuracy) ..., Schedule (time) ..., Cost ..., } \\
\text { Risk... }\end{array}$ \\
\hline Efficiency & 8 & $\begin{array}{l}\text { Advances in the software engineering tools have not kept up with the promises of peta-scale computing. } \\
\text { More importantly, the people and processes required to truly revolutionize the use of CSE in the } \\
\text { development process have not been considered as part of the approach to CSE applications. }\end{array}$ \\
\hline Efficiency & 8 & $\begin{array}{l}\text { Using CSE to reduce cycle time will have a greater overall influence on decreasing program costs and } \\
\text { justifying CSE applications than any other cost-cutting strategy. Trying to justify CSE only as an offset to } \\
\text { testing misses the best business case, since testing is only a small fraction of development costs. }\end{array}$ \\
\hline Efficiency & 8 & $\begin{array}{l}\text { The best way to minimize the impact of rework on cycle time is early discovery of defects. This will entail } \\
\text { improvements in design methodologies employed by aircraft companies coupled with improvements in } \\
\text { wind tunnel testing and modeling techniques. }\end{array}$ \\
\hline Efficiency & 15 & A test hour in 1950 produced far less "data" than a test hour today. \\
\hline Sustainment & 4 & $\begin{array}{l}\text { Historically, there has been no penalty for cancelling or delaying tests. This is especially true now given } \\
\text { surplus capacity. Facilities may also have an incentive to overestimate their demand in order to receive } \\
\text { extra annual funding or maintain staffing levels. As a result, aggregating individual facility forecasts have } \\
\text { been consistently higher than actual use. }\end{array}$ \\
\hline Sustainment & 4 & $\begin{array}{l}\text { We estimate total capacity of a wind tunnel by analyzing need for maintenance and upgrades, available } \\
\text { workforce, number of work-shifts the tunnel can operate, and other characteristics. }\end{array}$ \\
\hline
\end{tabular}




\begin{tabular}{|c|c|c|}
\hline Group & $\begin{array}{l}\text { Doc } \\
\text { Ref \# }\end{array}$ & Excerpted Material and Comments \\
\hline Sustainment & 5 & $\begin{array}{l}\text { Just as wind tunnels have been closing for past several decades for the myriad of reasons mentioned } \\
\text { above, the support for CFD research has been in steady decline for almost as long at the three NASA } \\
\text { aeronautics research centers (Ames, Glenn, and Langley). }\end{array}$ \\
\hline Sustainment & $9 a$ & $\begin{array}{l}\ldots \text { WT (wind tunnel)/PT (propulsion tunnel) facilities are vulnerable to budgetary shortfalls when } \\
\text { utilization falls. }\end{array}$ \\
\hline \multirow[t]{2}{*}{ Sustainment } & \multirow[t]{2}{*}{15} & $\begin{array}{l}\text { Development, investment, and maintenance of wind tunnel infrastructure occur over a very long period of } \\
\text { time, greatly exceeding the ability to predict the actual "need" for the capability and capacity. }\end{array}$ \\
\hline & & $\begin{array}{l}\text { Editor: It's hard to predict the future when designing new facilities; old facilities tend to have margin and } \\
\text { new ones not so much. }\end{array}$ \\
\hline \multirow[t]{2}{*}{ Sustainment } & \multirow[t]{2}{*}{15} & $\begin{array}{l}\text {... the cost of maintaining required wind tunnel infrastructure, let alone developing new test capabilities, } \\
\text { has been a very real and difficult challenge. Aging facilities, diminishing number of development } \\
\text { programs, ineffective business models, diminishing national investment in aeronautical research and } \\
\text { development, all combine to challenge those responsible for developing and maintaining this required } \\
\text { capability. }\end{array}$ \\
\hline & & Editor: The bean counters have taken over! \\
\hline Sustainment & 16 & $\begin{array}{l}\text {... with diminished opportunity to develop the next generation of test experts through hands-on test } \\
\text { experience and reporting, this world-class expertise had a predictable shelf life. }\end{array}$ \\
\hline Sustainment & 16 & $\begin{array}{l}\text { The third period - the current period of decline - started in the early 1990s with the end of the First Gulf } \\
\text { War. A "peace dividend" was declared, producing a 40-percent budget reduction across the DoD, } \\
\text { including AEDC. A major shift in philosophy overtook the aerospace industry manifested as a shift from } \\
\text { the early technical emphasis on "further, higher, faster" to a financial emphasis on "faster, better, } \\
\text { cheaper." (Internal Reference) It has become a very competitive environment, with reduced budgets that } \\
\text { have brought bottom-line-driven business people to top management positions. }\end{array}$ \\
\hline Investment & 8 & $\begin{array}{l}\text { Another cultural dynamic that impedes the successful application of CSE to major programs is the lack of } \\
\text { understanding that one needs to invest in a capability before taking the promised gains. }\end{array}$ \\
\hline \multirow[t]{2}{*}{ Investment } & \multirow[t]{2}{*}{14} & $\begin{array}{l}\text { A high-level notional assessment of the nation's current integrated T\&E capability to support HS/H } \\
\text { weapon system development is presented... }\end{array}$ \\
\hline & & $\begin{array}{l}\text { Editor: Context and approach - a way to graphically show attribute comparison; this shows goodness of } \\
\text { T\&E capabilities to support weapons systems requirements across speed ranges and over time. }\end{array}$ \\
\hline Investment & 14 & $\begin{array}{l}\text { During these four decades, the lack of investment in hypersonic test technologies and facilities has } \\
\text { prevented the testing community from keeping pace with the testing needs of hypersonic S\&T programs } \\
\text { and projected system applications. }\end{array}$ \\
\hline Investment & 15 & Development of a new test capability, in today's world, would require approximately a twenty-year effort. \\
\hline Investment & 19 & $\begin{array}{l}\text { It is difficult for ground test to compare with "free" computer time and three-year cycle computer systems } \\
\text { that are refreshed for much improved capability. }\end{array}$ \\
\hline \multirow[t]{2}{*}{ Workforce } & \multirow[t]{2}{*}{1} & $\begin{array}{l}\text { A study was performed at the Massachusetts Institute of Technology (Internal Reference) to understand } \\
\text { whether the application of large-scale computer simulation to the design process would offset the } \\
\text { inexperience of aircraft designers. . . The key findings from the study were as follows:: } \\
\text { - There is a strong linkage between experience and performance } \\
\text { - } \quad \text { 70s-era design efforts outperformed 90s-era in weight management } \\
\text { - Test phase is an important downstream indicator of design performance - test personnel understood } \\
\text { design flaws through exposure to recurring problems } \\
\text { Modern design tools are graphically compelling, but reduced experimental experience led to } \\
\text { deficiencies. }\end{array}$ \\
\hline & & $\begin{array}{l}\text { Editor: Tools may produce pretty pictures, but the understanding of the physics behind the pics is not as } \\
\text { robust. However, a skilled experimentalist can glean new understanding from these CFD results. }\end{array}$ \\
\hline Workforce & 1 & $\begin{array}{l}\text {... there has been a significant decline in the experience base of aeronautical designers and } \\
\text { developers. As shown in a RAND study, (Internal Reference) the experience base for post-WWII } \\
\text { engineers was approximately } 6-12 \text { new design aircraft per career. The number of new military aircraft } \\
\text { program starts per decade is shown in ... In the } 1950 \text { s there were } 60 \text { aircraft programs in various stages } \\
\text { of development. In contrast, an aerospace engineer starting his career today may experience only one, } \\
\text { maybe two new system designs during his or her career. }\end{array}$ \\
\hline Workforce & 2 & $\begin{array}{l}\text {... the NASA aeronautics budget has shrunk by approximately } 40 \text { percent from } 2006 \text { to } 2011 \text {. (Internal } \\
\text { Reference) However, during this same period, the NASA aeronautics civil servant workforce dropped } \\
\text { from } 1,449 \text { employees in } 2006 \text { to } 1,371.5 \text { in } 2011 \text {, or approximately } 4 \text { percent . . . Thus, a major } \\
\text { decrease in funding occurred, but civil servant staffing remained essentially unchanged. . the civil } \\
\text { service salaries now represent a much greater proportion of NASA's aeronautics budget than they did in } \\
2006 \text {. }\end{array}$ \\
\hline \multirow[t]{2}{*}{ Workforce } & \multirow[t]{2}{*}{8} & Advances in the software engineering tools have not kept up with the promises of peta-scale computing. \\
\hline & & $\begin{array}{l}\text { Editor: This has a workforce element - computational tools and expertise are not keeping pace with } \\
\text { hardware development. }\end{array}$ \\
\hline Workforce & $9 a$ & $\begin{array}{l}\text { A significant theme from users and test facility operators alike was the importance of a knowledgeable, } \\
\text { skilled, and motivated workforce to complement the technical hardware of the facility. Hardware alone is } \\
\text { not enough. Users also noted the value of having active researchers on hand at NASA R\&D facilities as } \\
\text { a major advantage. }\end{array}$ \\
\hline
\end{tabular}




\begin{tabular}{|c|c|c|}
\hline \multirow[t]{2}{*}{ Group } & $\begin{array}{l}\text { Doc } \\
\text { Ref \# }\end{array}$ & Excerpted Material and Comments \\
\hline & & $\begin{array}{l}\text { Editor: Workforce is critical - "the importance of a knowledgeable, skilled, and motivated workforce to } \\
\text { complement the technical hardware of the facility." }\end{array}$ \\
\hline Workforce & 19 & $\begin{array}{l}\text { A national will and leadership is needed to sustain funding to get young people into an area like } \\
\text { aerodynamics. }\end{array}$ \\
\hline \multirow[t]{2}{*}{ Strategic } & \multirow[t]{2}{*}{1} & $\begin{array}{l}\text { Another cultural dynamic that impedes the successful application of CSE to major programs is the lack of } \\
\text { understanding that one needs to invest in a capability before taking the promised gains. }\end{array}$ \\
\hline & & $\begin{array}{l}\text { Editor: 1) Investment is up front and along the way; gains typically occur after initial operating capability } \\
\text { is demonstrated and verified. In the meantime, whatever exists that is fielded must continue to be } \\
\text { supported. 2) The migration of work from experimental to computational is based on the assurance that } \\
\text { computational can provide needed (quality) information. Investment is necessary to develop, field, and } \\
\text { validate CSE before replacing experimental methods. }\end{array}$ \\
\hline \multirow[t]{2}{*}{ Strategic } & \multirow[t]{2}{*}{2} & $\begin{array}{l}\text { One of the major problems facing NASA's aeronautics program is that it has been directed to pursue a } \\
\text { large number of goals, but it clearly lacks the resources to accomplish more than a few of them. }\end{array}$ \\
\hline & & Editor: Challenge area: Larger scope than budget \\
\hline \multirow[t]{2}{*}{ Strategic } & \multirow[t]{2}{*}{7} & $\begin{array}{l}\text { Every Euro invested in aeronautics R\&D creates an equivalent additional value in the economy every } \\
\text { year thereafter. }\end{array}$ \\
\hline & & Editor: One element of a positive financial business case. \\
\hline \multirow[t]{2}{*}{ Strategic } & \multirow[t]{2}{*}{8} & $\begin{array}{l}\text {... it needs to be recognized that the aeronautical development community is very conservative. Their } \\
\text { design and development processes have been refined over generations of applications and are intended } \\
\text { to reduce risks. Coupled with the forecast for fewer major aeronautical system developments, it will be } \\
\text { challenging to have the industry perform a significant overhaul to their processes, no matter how } \\
\text { attractive CSE appears. }\end{array}$ \\
\hline & & $\begin{array}{l}\text { Editor: Aeronautical technologies are catalysts for innovation and spill-over into other economic and } \\
\text { technological sectors, thus contributing to the growth. Yet, the will and ability to transform processes } \\
\text { tends to be limited, extending the time to develop and implement CSE. }\end{array}$ \\
\hline \multirow[t]{2}{*}{ Strategic } & \multirow[t]{2}{*}{$9 \mathrm{a}$} & $\begin{array}{l}\text { Flight testing plays a dominant role during final refinement, validation, and safety verification of a } \\
\text { production aircraft ... flight testing complements but does not replace WT/PT facility testing. }\end{array}$ \\
\hline & & Editor: Very little in our paper on flight test integration; this is a significant area of need. \\
\hline \multirow[t]{2}{*}{ Strategic } & \multirow[t]{2}{*}{$9 a$} & $\begin{array}{l}\text {... when the Air Force experimented with recovering full costs from } 1969 \text { to } 1972, \text { AEDC found that their } \\
\text { prices became inherently unstable and unpredictable ... the test workload decreased dramatically, } \\
\text { which, in turn, drove up overhead costs and initiated a positive feedback loop that continued driving up } \\
\text { prices and driving away users. }\end{array}$ \\
\hline & & Editor: An important lesson. Did we learn from it? \\
\hline \multirow[t]{2}{*}{ Strategic } & \multirow[t]{2}{*}{$9 a$} & $\begin{array}{l}\text { It is important to retain perspective on the magnitude of NASA's WT/PT (wind tunnel/propulsion test) } \\
\text { facility costs relative to the investment value of the aerospace vehicles they enable or support. }\end{array}$ \\
\hline & & $\begin{array}{l}\text { Editor: Key point -WT/PT facilities are tools for research and some development that undergirds the } \\
\text { product pipeline for the nation's entire aeronautics industry. }\end{array}$ \\
\hline Strategic & $9 \mathrm{~b}$ & Foreign Reliance Might Be a Plausible Future Step, but Security Concerns Would Need to Be Addressed. \\
\hline Strategic & $9 b$ & $\begin{array}{l}\text { Lack of federal investments in new, more advanced facilities is forcing the retention of aging and } \\
\text { sometimes inferior infrastructure for strategically important capabilities }\end{array}$ \\
\hline \multirow[t]{2}{*}{ Strategic } & \multirow[t]{2}{*}{10} & $\begin{array}{l}\text { Aviation contributes an estimated } \$ 741 \text { billion to the U.S. economy or roughly } 5.6 \text { percent of the nation's } \\
\text { gross domestic product. Over } 11 \text { million jobs . . largest U.S. manufacturing exporter. }\end{array}$ \\
\hline & & Editor: (2010 numbers) \\
\hline \multirow[t]{2}{*}{ Strategic } & \multirow[t]{2}{*}{11} & $\begin{array}{l}\text { Historically, Federal departments and agencies that own or manage part of the aeronautics RDT\&E } \\
\text { infrastructure have independently planned, programmed, and budgeted for their own RDT\&E facility } \\
\text { resources and needs. }\end{array}$ \\
\hline & & $\begin{array}{l}\text { Editor: Stovepiped organizations often make decisions in their own best interests rather than from a } \\
\text { national need perspective. Combined with near-term, budget-driven decision-making, capabilities } \\
\text { needed for the future, including skills, are lost. }\end{array}$ \\
\hline \multirow[t]{2}{*}{ Strategic } & \multirow[t]{2}{*}{11} & $\begin{array}{l}\text {.. decisions involving investment in the infrastructure, divestment of infrastructure assets, and } \\
\text { scheduling of competing workload in those assets are normally based on individual department or } \\
\text { agency priorities. }\end{array}$ \\
\hline & & Editor: More stovepiping \\
\hline \multirow[t]{2}{*}{ Strategic } & \multirow[t]{2}{*}{13} & $\begin{array}{l}\text { The system development cycle time from the Milestone B (MS-B) decision to design and build the } \\
\text { system until the Initial Operational Capability (IOC) has dramatically increased over the last several } \\
\text { decades until the time from MS-B to IOC for the Joint Strike Fighter is well in excess of } 200 \text { months. }\end{array}$ \\
\hline & & Editor: Note how this and the Boeing decrease in wings tested conflict \\
\hline \multirow[t]{2}{*}{ Strategic } & \multirow[t]{2}{*}{18} & $\begin{array}{l}\text { Boeing decreased the number of wing configurations in wind tunnel testing from seventy-seven to five } \\
\text { between } 1980 \text { to } 2003 \text {. }\end{array}$ \\
\hline & & $\begin{array}{l}\text { Editor: Note how this (reducing test scope) and the preceding Joint Strike Fighter development time } \\
\text { (increasing) conflict! }\end{array}$ \\
\hline Strategic & 19 & If the wind tunnel is not there, we must build extra margin into the vehicle at increased cost and risk. \\
\hline
\end{tabular}




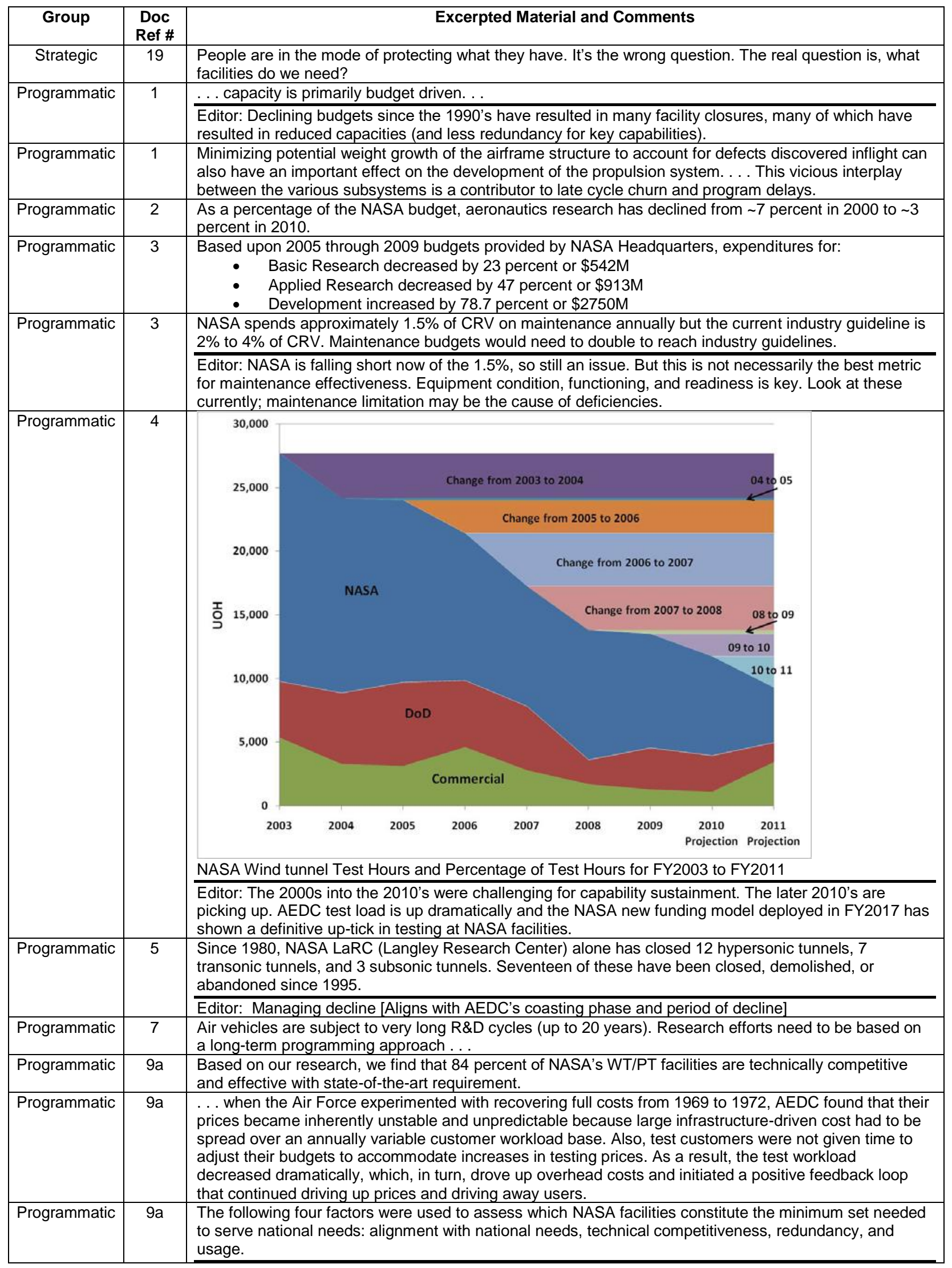




\begin{tabular}{|c|c|c|c|c|c|c|}
\hline Group & $\begin{array}{l}\text { Doc } \\
\text { Ref \# }\end{array}$ & \multicolumn{5}{|c|}{ Excerpted Material and Comments } \\
\hline & & \multicolumn{5}{|c|}{$\begin{array}{l}\text { Editor: This is in fundamental disagreement with NASA directives to align capabilities with NASA mission } \\
\text { needs - unless someone is willing to pay for and/or invest in NASA capabilities. }\end{array}$} \\
\hline Programmatic & $9 b$ & \multicolumn{5}{|c|}{$\begin{array}{l}\text { In search of lower costs and modern wind tunnel technology, U.S. customers typically conduct } 25 \text { percent } \\
\text { of their wind tunnel development at European facilities." }\end{array}$} \\
\hline Programmatic & 11 & \multicolumn{5}{|c|}{$\begin{array}{l}\text { This identification of the most critical shortfalls in the present Federal aeronautics RDT\&E infrastructure is } \\
\text { the first crucial step toward addressing infrastructure deficiencies that may hinder progress toward the } \\
\text { goals and objectives of the National Aeronautics R\&D Plan. }\end{array}$} \\
\hline Programmatic & 11 & \multicolumn{5}{|c|}{$\begin{array}{l}\text { Comprehensive interagency management policies for aeronautics infrastructure do not yet exist. It is } \\
\text { difficult to prioritize national RDT\&E needs across D\&A (Department and Agency) boundaries, particularly } \\
\text { given the existence of different budget processes and agency goals that are often reviewed by separate } \\
\text { Congressional committees. Challenges that may impede interagency cooperation include: } \\
\text { - Competing authorization and appropriations legislation amongst the various D\&As, which may } \\
\text { present legal and procedural barriers to the sharing of resources; } \\
\text { - Lack of imperative or incentive to prioritize and ensure the availability of facilities that are } \\
\text { inconsistently or intermittently used but that remain critical in those instances when they are } \\
\text { needed; } \\
\text { Lack of consistent cost accounting and usage policies driven by individual D\&A budgeting and } \\
\text { accounting practices that hinder sharing of agency resources and raise an access barrier for non- } \\
\text { Federal users; } \\
\text { High costs for infrastructure construction, maintenance, and upgrading, which may create } \\
\text { institutional barriers when considering the allocation of infrastructure resources to priorities outside } \\
\text { of the owning agency's mission. }\end{array}$} \\
\hline Programmatic & 13 & \multirow{2}{*}{\multicolumn{5}{|c|}{$\begin{array}{l}\text { The system development cycle time from the Milestone B (MS-B) decision to design and build the system } \\
\text { until the Initial Operational Capability (IOC) has dramatically increased over the last several decades. } \\
\text { Program data requirements vary dramatically and are affected by factors such as configuration complexity, } \\
\text { operational limits (Mach, AOA, AOS), weapons or carriage requirements, high lift systems, similarity to } \\
\text { other configurations, etc. }\end{array}$}} \\
\hline Programmatic & 15 & & & & & \\
\hline \multirow[t]{4}{*}{ Programmatic } & \multirow[t]{4}{*}{15} & & 1950 & 2007 & \% Change & \\
\hline & & Test hours/program & 1746 & 40444 & $2300 \%$ & \\
\hline & & Total Data Runs (/1000)/program & 2.88 & 241.6 & $8300 \%$ & \\
\hline & & Test Efficiency Changes (runs/hour) & 1.7 & 6.0 & $350 \%$ & \\
\hline \multirow[t]{2}{*}{ Programmatic } & \multirow[t]{2}{*}{16} & \multicolumn{5}{|c|}{$\begin{array}{l}\text { One of the key factors contributing to cost and schedule overruns in major acquisition programs has } \\
\text { been the lack of maturity of new technologies injected into the system design. }\end{array}$} \\
\hline & & \multicolumn{5}{|c|}{ Editor: Might the reduced research of the 2000 s be a significant contributing factor? } \\
\hline \multirow[t]{2}{*}{ Programmatic } & \multirow[t]{2}{*}{16} & \multicolumn{5}{|c|}{$\begin{array}{l}\text { Too much emphasis on improving the efficiency of testing, faster and cheaper tests, fewer facilities, } \\
\text { fewer personnel. }\end{array}$} \\
\hline & & \multicolumn{5}{|c|}{$\begin{array}{l}\text { Editor: Efficiency was a false flag. In the 1990s at AEDC, the goal was repeatedly to cut station keepers } \\
50 \% \text {. }\end{array}$} \\
\hline \multirow[t]{2}{*}{ Programmatic } & \multirow[t]{2}{*}{18} & \multicolumn{5}{|c|}{$\begin{array}{l}\ldots \text { the number of major U.S. test facilities has been reduced by nearly } 50 \text { percent within a } 24-y e a r \\
\text { period ( } 1985 \text { to } 2009) \text {. }\end{array}$} \\
\hline & & \multicolumn{5}{|c|}{ Editor: Automotive facilities are not represented and blossomed at the turn of the millennia } \\
\hline \multirow[t]{2}{*}{ Programmatic } & 19 & \multicolumn{5}{|c|}{$\begin{array}{l}\text { Industry and government should bite the bullet and pay to keep these [EFD/CFD?] facilities open and } \\
\text { free for us to use. If you have more demand for test time than you have time available, let management } \\
\text { decide who gets the time. }\end{array}$} \\
\hline & & \multicolumn{5}{|c|}{$\begin{array}{l}\text { Editor: This is difficult, as there are costs to bear and outside users should bear some of this burden. } \\
\text { One possible path is the mutually beneficial cooperative testing, where both parties contribute and } \\
\text { receive benefit. }\end{array}$} \\
\hline Programmatic & 19 & \multicolumn{5}{|c|}{$\begin{array}{l}\text { We don't know how to measure the infrastructure cost of CFD (high-end computers, personnel, etc.). } \\
\text { What accounts most for this lack of understanding: accounting practice differences for CFD and GT, } \\
\text { externally-driven accounting metrics (i.e., finance). }\end{array}$} \\
\hline \multirow[t]{2}{*}{$\begin{array}{l}\text { Systems } \\
\text { Integration }\end{array}$} & 1 & \multicolumn{5}{|c|}{$\begin{array}{l}\text { The major defects frequently found late in the development cycle for a flight system usually occur at the } \\
\text { interface of major subsystems, e.g., aerodynamically induced structural failures. }\end{array}$} \\
\hline & & \multicolumn{5}{|c|}{$\begin{array}{l}\text { Editor: This is a major key point, contributing to the extended development times and costs, as well as } \\
\text { ultimate product performance. }\end{array}$} \\
\hline \multirow[t]{2}{*}{$\begin{array}{l}\text { Systems } \\
\text { Integration }\end{array}$} & 1 & \multicolumn{5}{|c|}{$\begin{array}{l}\text { At the same time computer systems have advanced, so has the complexity of aeronautical systems. } \\
\text { Over the last 30years, expanded flight envelopes, super-maneuverability, super-cruise, low observables, } \\
\text { and advances in materials technology have made it more challenging to model the physics of military } \\
\text { flight systems. }\end{array}$} \\
\hline & & \multicolumn{5}{|c|}{$\begin{array}{l}\text { Editor: Similar for ground testing - efficiency gains and improved test and measurement techniques have } \\
\text { been offset by complexity. Doesn't mean it's not worth it, but instead of realizing cycle time gains, the } \\
\text { product requires more work. }\end{array}$} \\
\hline
\end{tabular}




\begin{tabular}{|c|c|c|}
\hline Group & $\begin{array}{l}\text { Doc } \\
\text { Ref \# }\end{array}$ & Excerpted Material and Comments \\
\hline \multirow[t]{2}{*}{$\begin{array}{l}\text { Systems } \\
\text { Integration }\end{array}$} & \multirow[t]{2}{*}{8} & $\begin{array}{l}\text { Airframe/structure integration is arguably the most important of the integration issues that need to be } \\
\text { resolved early in the design cycle. }\end{array}$ \\
\hline & & $\begin{array}{l}\text { Editor: Noted above is that this is where major defects are found late in the development cycle - a major } \\
\text { driver for improved testing and modeling earlier during design formulation. }\end{array}$ \\
\hline \multirow[t]{2}{*}{$\begin{array}{l}\text { Systems } \\
\text { Integration }\end{array}$} & \multirow[t]{2}{*}{11} & $\begin{array}{l}\text { Historically, Federal departments and agencies that own or manage part of the aeronautics RDT\&E } \\
\text { infrastructure have independently planned, programmed, and budgeted for their own RDT\&E facility } \\
\text { resources and needs. Over time, the interdependence of the Federal agencies for specific types of } \\
\text { infrastructure has increased as technology has advanced, as development has become more complex, } \\
\text { and as research focuses for individual D\&As have changed. }\end{array}$ \\
\hline & & Editor: Stovepiping; noted earlier \\
\hline $\begin{array}{l}\text { Systems } \\
\text { Integration }\end{array}$ & 13 & $\begin{array}{l}\text { In spite of increases in testing efficiencies, a nominal wind tunnel campaign requires } 22,000 \text { Occupancy } \\
\text { Hours in an array of wind tunnels and } 6-8,000 \text { sorties for the flight test campaign. The typical wind tunnel } \\
\text { campaign requires nominally } 4 \text { years while the typical flight test program requires } 6-8 \text { years - a total of } \\
10-12 \text { years of developmental testing cycle time. }\end{array}$ \\
\hline \multirow[t]{2}{*}{$\begin{array}{l}\text { Systems } \\
\text { Integration }\end{array}$} & \multirow[t]{2}{*}{13} & $\begin{array}{l}\text { Surprisingly, wind tunnel campaigns are traditionally designed around test hours, not test points. That is } \\
\text { why a fourfold increase in test productivity generated by the wind tunnel community in the 1990s had } \\
\text { essentially no impact on reducing the number of wind tunnel hours for the F-35 program. (Internal } \\
\text { References) }\end{array}$ \\
\hline & & $\begin{array}{l}\text { Editor: Test hours are an artifact from earlier times - easy to measure and correlate with staff man hours } \\
\text { and (roughly) power usage. Not usually a very good measure of value. }\end{array}$ \\
\hline $\begin{array}{l}\text { Systems } \\
\text { Integration }\end{array}$ & 15 & $\begin{array}{l}\text { The need for much more data can be attributed to a wide range of factors including much higher } \\
\text { performance aircraft, the advent of digital flight control systems (and the need for extensive data for flight } \\
\text { control law development), the increased desire to avoid the high cost and risk of flight test development, } \\
\text { and integration of aerodynamic and propulsion systems. }\end{array}$ \\
\hline $\begin{array}{l}\text { Systems } \\
\text { Integration }\end{array}$ & 16 & $\begin{array}{l}\text {. . a structural flaw found very late in the development cycle of a fighter aircraft can easily drive a billion } \\
\text { dollar plus bill when the time and cost to redesign, rebuild, retest, and modify production tooling are } \\
\text { accounted for. On average, ten structural flaws of varying importance are discovered during } \\
\text { developmental flight testing. }\end{array}$ \\
\hline \multirow[t]{2}{*}{$\begin{array}{l}\text { Systems } \\
\text { Integration }\end{array}$} & \multirow[t]{2}{*}{17} & $\begin{array}{l}\text { Design and fabrication of the wind tunnel model may take several months and often include } \\
\text { subcomponent tests to ensure that the model will provide the appropriate level of data quality. }\end{array}$ \\
\hline & & $\begin{array}{l}\text { Editor: Model design and fab typically comes after much of the product design is complete and supports } \\
\text { testing to provide (or confirm) both system level and detail designs. So this time can be crucial, impacting } \\
\text { the product development critical path. }\end{array}$ \\
\hline
\end{tabular}

\section{B. Current State}

\begin{tabular}{|c|c|c|}
\hline Group & $\begin{array}{l}\text { Doc } \\
\text { Ref \# }\end{array}$ & Excerpted Material and Editorial Comments \\
\hline \multirow[t]{2}{*}{ Approach } & \multirow[t]{2}{*}{14} & $\begin{array}{l}\text { Currently, insufficient in-house technical expertise and analysis tools are available to support hypersonic } \\
\text { flight-test planning and engineering analysis activities. }\end{array}$ \\
\hline & & $\begin{array}{l}\text { Editor: Boom-bust cycles and general neglect (specialized market with more limited monetization potential) } \\
\text { has impacted; currently trying to ramp up and reconstitute. Will this build into the future or until the next } \\
\text { bust? }\end{array}$ \\
\hline Approach & 18 & Adequate tunnel facilities are still available to address normal low-speed testing. \\
\hline Approach & 18 & $\begin{array}{l}\text { Facilities to test transports, high-altitude ISR, and time-critical-to-target platforms are reaching critical } \\
\text { mass; and they are in need of major upgrades or maintenance to continue operation. In addition, to answer } \\
\text { the government's challenge of advancing our technology to reduce energy consumption, reduce noise } \\
\text { impact, and improve vehicle performance, these major tunnel facilities will need to support non-traditional } \\
\text { concept entries requiring unique or innovative test methodology. }\end{array}$ \\
\hline \multirow[t]{2}{*}{ Approach } & \multirow[t]{2}{*}{19} & Customer accuracy requirements are becoming more stringent. \\
\hline & & $\begin{array}{l}\text { Editor: With few to no new facilities, this requires investment in existing capabilities to improve to meet } \\
\text { these requirements. }\end{array}$ \\
\hline \multirow[t]{2}{*}{$\begin{array}{l}\text { GT/CFD } \\
\text { Integration }\end{array}$} & \multirow[t]{2}{*}{5} & $\begin{array}{l}\text { CFD validation against experimental data is crucial, and this is essentially why, for example, automobile } \\
\text { companies have continued to build new wind tunnels, particularly for aeroacoustic considerations. }\end{array}$ \\
\hline & & Editor: See earlier statement \\
\hline \multirow[t]{2}{*}{$\begin{array}{l}\text { GT/CFD } \\
\text { Integration }\end{array}$} & \multirow[t]{2}{*}{8} & $\begin{array}{l}\text { Increasing the use of CSE versus testing is a two-edged sword relative to the technical talent involved in } \\
\text { aeronautical system development. On the one hand, visual output from high-fidelity models provides } \\
\text { unprecedented insight into flow features that cannot be obtained in any other way. ... On the other hand, } \\
\text { having a generation of engineers experienced only in the "zeros and ones" of advanced modeling has the } \\
\text { downside of limiting real understanding of the physics of the problem, especially when extending into } \\
\text { realms beyond the physical fidelity of the model. }\end{array}$ \\
\hline & & $\begin{array}{l}\text { Editor: Engineers must understand the physics and drivers of variabilities (what's inside the black box). } \\
\text { This tends to come from experimental experience. }\end{array}$ \\
\hline
\end{tabular}




\begin{tabular}{|c|c|c|}
\hline $\begin{array}{l}\text { GT/CFD } \\
\text { Integration }\end{array}$ & 8 & $\begin{array}{l}\text {... advanced computer-based control systems in modern military aircraft actually drive a need for even } \\
\text { more wind tunnel data per configuration to ensure accurate control variables over the entire flight envelope. }\end{array}$ \\
\hline $\begin{array}{l}\text { GT/CFD } \\
\text { Integration }\end{array}$ & 8 & $\begin{array}{l}\text { What is frequently overlooked by the CSE community desiring to replace testing is that test facilities are } \\
\text { used to predict not only the performance, but also the operability, reliability, and maintainability of an } \\
\text { aeronautical system. }\end{array}$ \\
\hline Efficiency & 17 & $\begin{array}{l}\text { One of the latest improvements that has reduced costs is the use of computer systems on the moveable } \\
\text { wind tunnel test sections; this innovation permits investigators to check out a test article without } \\
\text { disconnecting and reconnecting leads when the wind tunnel test begins. One of the newest techniques } \\
\text { enabling faster acquisition of data is the use of continuous sweep. }\end{array}$ \\
\hline Efficiency & 17 & The polars per operating hour of $16 \mathrm{~T}$ have nearly doubled in the last 20 years. \\
\hline \multirow[t]{2}{*}{ Workforce } & \multirow[t]{2}{*}{18} & $\begin{array}{l}\text { Tools such as "rapid prototyping" and high-speed machining are being used to significantly reduce both } \\
\text { the cost and time required for model fabrication. }\end{array}$ \\
\hline & & $\begin{array}{l}\text { Editor: This is important in addressing cycle time concerns expressed in Table } 10 \text { for time to design and } \\
\text { fabricate models. }\end{array}$ \\
\hline Workforce & 1 & $\begin{array}{l}\ldots \text { there has been a significant decline in the experience base of aeronautical designers and developers } \\
\ldots \text { the experience base for post-WWII engineers was approximately } 6-12 \text { new design aircraft per career. } \\
\ldots \text { In contrast, an aerospace engineer starting his career today may experience only one, maybe two new } \\
\text { system designs during his or her career. }\end{array}$ \\
\hline Workforce & $9 a$ & $\begin{array}{l}\text { For most aeronautic testing, WT/PT facilities remain the most viable and cost-effective tools for predicting } \\
\text { aeronautic behavior. }\end{array}$ \\
\hline Workforce & 14 & $\begin{array}{l}\text {... insufficient in-house technical expertise and analysis tools are available to support hypersonic flight- } \\
\text { test planning and engineering analysis activities. These activities include test engineering, test operations, } \\
\text { and M\&S capabilities over diverse flight regimes and test environments. }\end{array}$ \\
\hline \multirow[t]{2}{*}{ Workforce } & \multirow[t]{2}{*}{16} & $\begin{array}{l}\text { It is recognized that the paraprofessional and craft workforces contribute immensely to the technical } \\
\text { reputation of } A E D C \text { and require technical excellence to conduct their jobs. }\end{array}$ \\
\hline & & $\begin{array}{l}\text { Editor: This is very important - it takes many skill types to produce a successful ground test, including } \\
\text { different types of engineers, crafts/technicians/operators, software developers, and other support } \\
\text { personnel. }\end{array}$ \\
\hline Workforce & 16 & $\begin{array}{l}\text { Administrative workload on technical workers decreases time to develop technical skills, gain hands-on } \\
\text { experience, and/or document technical activities. }\end{array}$ \\
\hline \multirow[t]{2}{*}{ Workforce } & \multirow[t]{2}{*}{19} & $\begin{array}{l}\text { The education system is becoming much more multi-disciplinary. Need young people with the ability to } \\
\text { see the big picture. Meaningful work is important. Should not just have young people tracking down } \\
\text { drawings, etc. The work must interest them. }\end{array}$ \\
\hline & & $\begin{array}{l}\text { Editor: Specialist vs generalist - this is a real concern as the direction of skill needs points toward people } \\
\text { with at least working skills in both experimental and computational disciplines while also still needing } \\
\text { subject matter experts in each. How does this align with the culture of the current generations? }\end{array}$ \\
\hline Workforce & 19 & $\begin{array}{l}\text { We have training regimens, but it takes years of experience to become an expert. It's difficult enough } \\
\text { without trying in another discipline. }\end{array}$ \\
\hline Strategic & 14 & $\begin{array}{l}\text { Test capability technical needs and timing have been focused on potential flight systems that may result } \\
\text { from the S\&T technologies being pursued by the NAI program plan. (Internal References) }\end{array}$ \\
\hline \multirow[t]{2}{*}{ Strategic } & \multirow[t]{2}{*}{16} & $\begin{array}{l}\text { In reviewing the almost six-decade history of AEDC, the teams found that several key attributes that } \\
\text { historically contributed to building technical excellence are still in evidence: } \\
\text { A. Excitement in and innovation potential of the mission } \\
\text { B. Organizational and leadership emphasis on technical excellence } \\
\text { C. Opportunities for the staff to be technical and create knowledge } \\
\text { D. Technical collaboration } \\
\text { E. Focused emphasis on developing technical people } \\
\text { F. Knowledge archiving }\end{array}$ \\
\hline & & $\begin{array}{l}\text { Editor: Broadly applicable? Several of these things were reduced (benefits long-term) in the 1990s and } \\
2000 \text { s as budgets were reduced and are actively being restored and reinvigorated as they are recognized } \\
\text { as being critical for technical excellence. }\end{array}$ \\
\hline Programmatic & 3 & $\begin{array}{l}\text { The innovation and advanced technologies required to advance aeronautics, explore the outer planets, } \\
\text { understand the beginnings of the universe have been severely restricted by the short-term perspective and } \\
\text { funding. }\end{array}$ \\
\hline
\end{tabular}




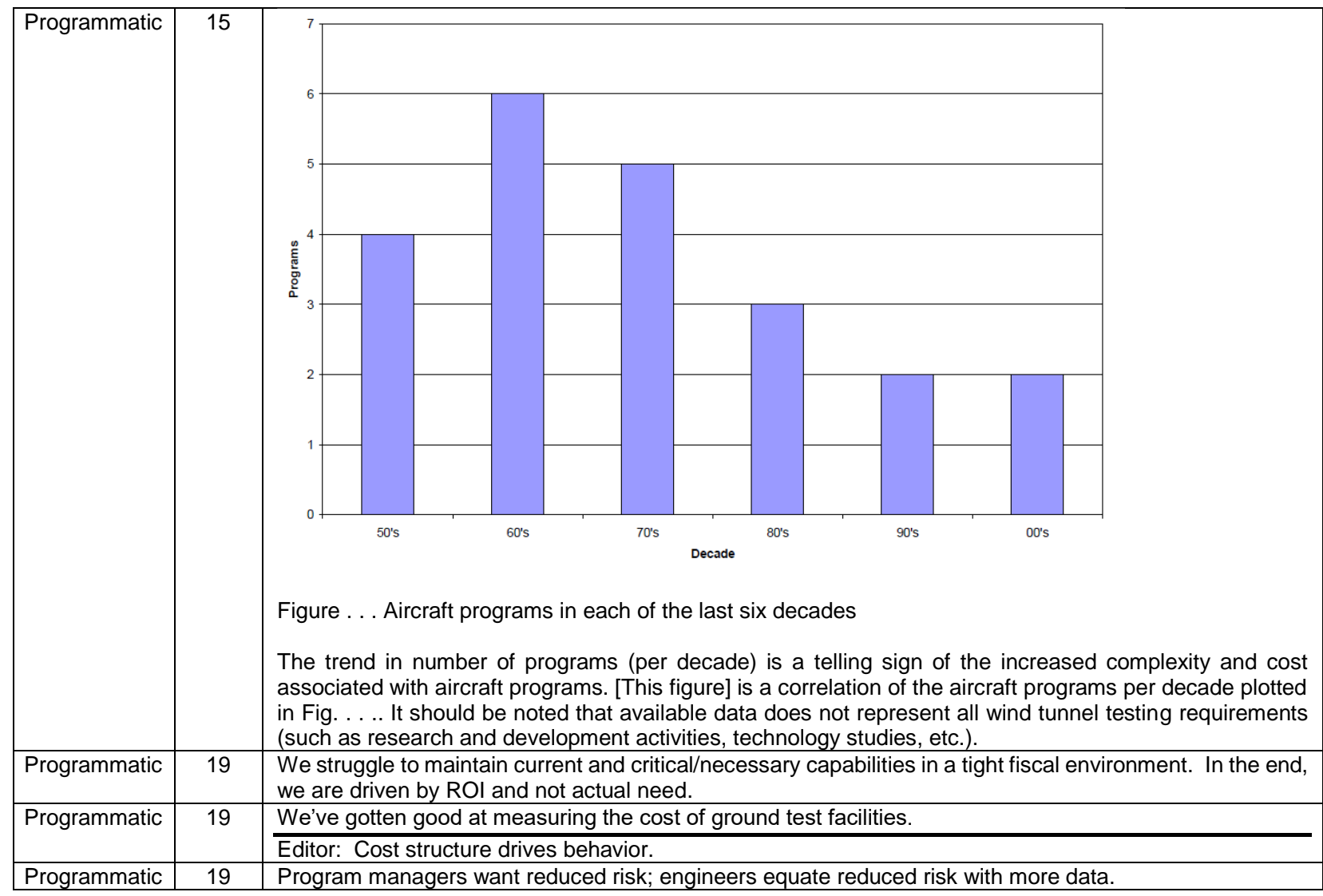

\section{Computational Current/Future}

\begin{tabular}{|c|c|c|}
\hline Group & $\begin{array}{c}\text { Doc } \\
\text { Ref \# }\end{array}$ & Excerpted Material and Editorial Comments \\
\hline \multirow[t]{2}{*}{ Approach } & \multirow[t]{2}{*}{1} & $\begin{array}{l}\ldots \text { a commercial aircraft company owns the entire design and development process, maintains its own } \\
\text { databases and tools as a competitive edge, and sustains a critical mass of experienced practitioners. }\end{array}$ \\
\hline & & Editor: More stovepiping. \\
\hline \multirow[t]{2}{*}{ Approach } & \multirow[t]{2}{*}{6} & $\begin{array}{l}\text {... CFD modeling capability grows to capture the required scope and physics to answer the questions } \\
\text { raised during testing. . . the expense of responding to often unplanned technical surprises ... that drives } \\
\text { conservatism into aerospace designs, and is a significant motivation for improving the accuracy and speed } \\
\text { of CFD. }\end{array}$ \\
\hline & & $\begin{array}{l}\text { Editor: Defining the rules/measures are key to understanding when "good" is good enough (relative to } \\
\text { conservative designs). }\end{array}$ \\
\hline \multirow[t]{2}{*}{ Approach } & \multirow[t]{2}{*}{13} & $\begin{array}{l}\text { This technology thrust is referred to as the "Digital Twin" with a long term goal of using physics-based } \\
\text { modeling and probabilistic analysis to forecast the life cycle by part number and by aircraft tail number of } \\
\text { structural elements with the intent to reduce the cost of Operations and Sustainment. }\end{array}$ \\
\hline & & $\begin{array}{l}\text { Editor: An important tool that will become more important, even ubiquitous. Relates to performance, } \\
\text { operability, maintainability, life cycle analyses, training, and more. Also provides bridging between } \\
\text { computational and experimental techniques. At the present time, these tools are used more for mechanical } \\
\text { applications at the system level ... }\end{array}$ \\
\hline Approach & 13 & $\begin{array}{l}\text { The "Digital Thread" as envisioned in the Global Horizons report and AF Engineering Enterprise Strategic } \\
\text { Plan is intended to expand the principles of MBE (model based engineering), industry's digital thread, and } \\
\text { the Digital Twin to encompass the entire life cycle from early research through development planning, } \\
\text { design and manufacture, testing, operations, sustainment, and training... }\end{array}$ \\
\hline \multirow[t]{2}{*}{ Approach } & \multirow[t]{2}{*}{14} & $\begin{array}{l}\text { The current tools are mostly stand-alone and are not necessarily standardized across the ranges. The } \\
\text { vision would be to have an automated suite of tools integrated with flight prediction models, IIP } \\
\text { (instantaneous impact predictor) models, debris dispersion models, and flight simulators. }\end{array}$ \\
\hline & & $\begin{array}{l}\text { Editor: Stovepipes. Vision will require both cost sharing and developing a process that protects intellectual } \\
\text { property while supporting common platforms and tools. }\end{array}$ \\
\hline $\begin{array}{l}\text { GT/CFD } \\
\text { Integration }\end{array}$ & 1 & $\begin{array}{l}\text { More importantly, the people and processes required to truly revolutionize the use of CSE in the } \\
\text { development process have not been considered as part of the approach to CSE applications. }\end{array}$ \\
\hline
\end{tabular}




\begin{tabular}{|c|c|c|}
\hline & & $\begin{array}{l}\text { Editor: Has there been too much focus on tools? Application requires people that understand both the } \\
\text { physics and tools. A difficult balance to strike. }\end{array}$ \\
\hline $\begin{array}{l}\text { GT/CFD } \\
\text { Integration }\end{array}$ & 1 & $\begin{array}{l}\text { The question is not can CFD give a great answer for one or two test cases, but can the CFD "processes" } \\
\text { give good answers for a range of cases when run by a competent engineer? }\end{array}$ \\
\hline \multirow[t]{2}{*}{$\begin{array}{l}\text { GT/CFD } \\
\text { Integration }\end{array}$} & \multirow[t]{2}{*}{1} & $\begin{array}{l}\text { Industry chose to stay at modest levels of computing capability in the } 1990 \text { s and rely on government } \\
\text { investments to have access to larger systems. . . National capabilities may need to be scheduled for } \\
\text { dedicated applications to major systems in development much as government national wind tunnels are } \\
\text { scheduled. There may not be enough peta-scale computing capacity at the national level to simultaneously } \\
\text { support the S\&T and aeronautical engineering community during a major DoD development... Clearly, a } \\
\text { strategy for providing sufficient capacity as well as a CONOPS to support design and development of } \\
\text { systems will be required to enable any potential success for large-scale application of CSE to the } \\
\text { development process. }\end{array}$ \\
\hline & & Editor: Combination of stovepiping, letting government foot the bill, and industry focus on development. \\
\hline $\begin{array}{l}\text { GT/CFD } \\
\text { Integration }\end{array}$ & 5 & Can engineering data be obtained more cheaply with the use of CFD over alternative sources? \\
\hline \multirow[t]{2}{*}{$\begin{array}{l}\text { GT/CFD } \\
\text { Integration }\end{array}$} & \multirow[t]{2}{*}{5} & $\begin{array}{l}\text { At the current state of technology, CFD engineers may spend much more time just setting up a computer } \\
\text { job. Large database requirements (hundreds of thousands of individual flight conditions) may be met } \\
\text { cheaper via wind-tunnel testing for a long time into the future. }\end{array}$ \\
\hline & & $\begin{array}{l}\text { Editor: This is probably not intuitive to most. For example, CFD can't build the S\&C database in a timely } \\
\text { manner. }\end{array}$ \\
\hline \multirow[t]{2}{*}{$\begin{array}{l}\text { GT/CFD } \\
\text { Integration }\end{array}$} & \multirow[t]{2}{*}{5} & $\begin{array}{l}\text { The bulk, if not all, of the CFD is based on nonlinear methods including full potential with coupled boundary } \\
\text { layer, Euler, and RANS. To be able to expand the use of CFD over the entire flight envelope, considerable } \\
\text { progress in algorithm, physics modeling, and hardware technology is still necessary. }\end{array}$ \\
\hline & & Editor: Last sentence summarizes the challenge \\
\hline \multirow{2}{*}{$\begin{array}{l}\text { GT/CFD } \\
\text { Integration }\end{array}$} & \multirow[t]{2}{*}{5} & Is the degree to which CFD data can be trusted understood? \\
\hline & & Editor: Again, what defines when good is good enough? \\
\hline $\begin{array}{l}\text { GT/CFD } \\
\text { Integration }\end{array}$ & 5 & The trade-off between CFD and wind-tunnel test data is not yet clear for new, revolutionary configurations. \\
\hline \multirow[t]{2}{*}{$\begin{array}{l}\text { GT/CFD } \\
\text { Integration }\end{array}$} & \multirow[t]{2}{*}{6} & $\begin{array}{l}\text { Emphasis on physics-based, predictive modeling. In particular, transition, turbulence, separation, } \\
\text { chemically-reacting flows, radiation, heat transfer, and constitutive models must reflect the underlying } \\
\text { physics more closely than ever done before. }\end{array}$ \\
\hline & & Editor: CFD will need future experiments to do this. \\
\hline \multirow[t]{2}{*}{$\begin{array}{l}\text { GT/CFD } \\
\text { Integration }\end{array}$} & \multirow[t]{2}{*}{6} & $\begin{array}{l}\text { Management of errors and uncertainties resulting from all possible sources: (a) physical modeling errors } \\
\text { and uncertainties addressed in item (Internal Reference), (b) numerical errors arising from mesh and } \\
\text { discretization inadequacies, and (c) aleatory uncertainties derived from natural variability as well as } \\
\text { epistemic uncertainties due to lack of knowledge in the parameters of a particular fluid flow problem. }\end{array}$ \\
\hline & & Editor: Uncertainty management already is a requirement for experiments and needs to be for CFD. \\
\hline $\begin{array}{l}\text { GT/CFD } \\
\text { Integration }\end{array}$ & 6 & $\begin{array}{l}\text {... in } 2030 \text { many of the aerospace engineering problems of interest will be of a multi-disciplinary nature } \\
\text { and CFD will have to interface seamlessly with other high-fidelity analyses including acoustics, structures, } \\
\text { heat transfer, reacting flow, radiation, dynamics \& control, and even ablation and catalytic reactions in } \\
\text { thermal protection systems. }\end{array}$ \\
\hline \multirow[t]{2}{*}{$\begin{array}{l}\text { GT/CFD } \\
\text { Integration }\end{array}$} & \multirow[t]{2}{*}{8} & $\begin{array}{l}\text { Quick turnaround computing to support interactive design is essential. This intensity of schedule, accuracy, } \\
\text { and volume cannot be supported by competing in a queue with S\&T projects (i.e., a dedicated facility will } \\
\text { be required). }\end{array}$ \\
\hline & & $\begin{array}{l}\text { Editor: Important points }-1 \text { ) having a range of computational tools to match needs, not one size fits all that } \\
\text { takes too long and 2) having the agility to interact on a near real-time basis with ongoing experiments (and } \\
\text { not having to wait in the processing line with nonrelated work). }\end{array}$ \\
\hline $\begin{array}{l}\text { GT/CFD } \\
\text { Integration }\end{array}$ & $9 a$ & $\begin{array}{l}\text { The technology is not yet considered reliable for predicting the characteristics of the complex separated } \\
\text { flows that dominate many critical design points for an aircraft. }\end{array}$ \\
\hline \multirow[t]{2}{*}{$\begin{array}{l}\text { GT/CFD } \\
\text { Integration }\end{array}$} & \multirow[t]{2}{*}{18} & $\begin{array}{l}\text { Future CFD applications . . . will evolve towards multidisciplinary studies for system design and } \\
\text { optimization. Moving control surfaces, computational maneuverability, and vehicle systems with integrated } \\
\text { propulsion are all prime application areas of interest. The net effect of this new generation of applications } \\
\text { will be an increasing reliance on CFD modeling for aerodynamic design and systems optimization where } \\
\text { wind tunnel modeling cannot be so easily or cost-effectively applied. }\end{array}$ \\
\hline & & $\begin{array}{l}\text { Editor: As noted before, CFD will transition when it makes sense and GT will move into more of a support } \\
\text { (verification and some physics investigations) role. }\end{array}$ \\
\hline $\begin{array}{l}\text { GT/CFD } \\
\text { Integration }\end{array}$ & 19 & As we move from a conventional tube plus wing to blended bodies, there is less confidence in CFD. \\
\hline $\begin{array}{l}\text { GT/CFD } \\
\text { Integration }\end{array}$ & 19 & Complex CFD solutions require a lot of computing time for high-fidelity results. \\
\hline $\begin{array}{l}\text { GT/CFD } \\
\text { Integration }\end{array}$ & 19 & $\begin{array}{l}\text { CFD tools in recent years: 1) It can't handle highly integrated problems yet, 2) This equates to need for } \\
\text { more and more complex experimental testing, for fewer data points, but with higher accuracy, 3) The wind } \\
\text { tunnel element of EFD (i.e., GT) is used for validation now, but are moving away from developmental roles } \\
\text { to characterization. }\end{array}$ \\
\hline $\begin{array}{l}\text { GT/CFD } \\
\text { Integration }\end{array}$ & 19 & Our culture is that the wind tunnel is always correct compared to CFD. \\
\hline
\end{tabular}




\begin{tabular}{|c|c|c|}
\hline & & $\begin{array}{l}\text { Editor: Wind tunnels are another form of simulation; real physics that may or may not align with actual flight } \\
\text { physics. }\end{array}$ \\
\hline \multirow{2}{*}{$\begin{array}{l}\text { GT/CFD } \\
\text { Integration }\end{array}$} & \multirow[t]{2}{*}{19} & You can get whole properties when you conduct CFD. \\
\hline & & Editor: CFD will always give you an answer. Again, how good? \\
\hline Efficiency & 5 & $\begin{array}{l}\text { With another } 10 \text { to } 20 \text { years of Moore's Law advancements and assuming that research in relevant } \\
\text { numerical and flow physics issues is successful in developing an accurate turbulence-modeling approach } \\
\text { for complex flows, CFD could primarily replace wind tunnels for off-design conditions. }\end{array}$ \\
\hline Efficiency & 8 & $\begin{array}{l}\text { CSE does, however, offer significant potential to impact the overall wind tunnel campaign in three } \\
\text { significant areas. First, and most importantly, CSE can be used to reduce the overall workload. Second, } \\
\text { CSE, if applied appropriately, can reduce downstream effects of late defect discovery on total development } \\
\text { cycle time. Third, CSE can be used to integrate major subsystems earlier in the development cycle } \\
\text { avoiding late integration issues. }\end{array}$ \\
\hline \multirow[t]{2}{*}{ Investment } & \multirow[t]{2}{*}{5} & $\begin{array}{l}\text { An urgent need exists to reinvigorate research in computational science and engineering at NASA, as well } \\
\text { as to provide access to the state-of-the-art computer hardware to NASA scientists. }\end{array}$ \\
\hline & & $\begin{array}{l}\text { Editor: Investment. The recent move to explore supersonic modeling and simulation utilizing experiments } \\
\text { at the 4ft UPWT (Unitary Plan Wind Tunnel) at NASA Langley would seem to be a strong move in support } \\
\text { of this statement. This also should result in improvements in the experimental capabilities. }\end{array}$ \\
\hline \multirow[t]{2}{*}{ Investment } & \multirow[t]{2}{*}{5} & $\begin{array}{l}\text { Because the solution cost of high-order methods varies strongly with grid size, robust grid adaptation is } \\
\text { needed to optimally distribute the grid and minimize the overall grid size. Therefore, the success of high- } \\
\text { order-methods technology requires advancement in efficient solvers, as well as high-fidelity grid generation } \\
\text { and adaptation. }\end{array}$ \\
\hline & & Editor: Gridding technique development is key to both quality and efficiency. \\
\hline Investment & 5 & $\begin{array}{l}\text { In order to advance the state of the art of computational technology for aeronautics applications, CFD } \\
\text { research must progress along multiple paths... }\end{array}$ \\
\hline Investment & 5 & $\begin{array}{l}\text { Research in grid generation is generally under-valued, but it is important to note that grid generation is not } \\
\text { a solved problem. }\end{array}$ \\
\hline Investment & 6 & $\begin{array}{l}\text { Despite considerable past success, today there is a general feeling that CFD development for single and } \\
\text { multi-disciplinary aerospace engineering problems has been stagnant for some time, caught between } \\
\text { rapidly changing HPC hardware, the inability to predict adequately complex separated turbulent flows, and } \\
\text { the difficulties incurred with increasingly complex software driven by complex geometry and increasing } \\
\text { demands for multidisciplinary simulations. }\end{array}$ \\
\hline \multirow[t]{2}{*}{ Investment } & \multirow[t]{2}{*}{6} & $\begin{array}{l}\text { An integral part of effectively using the advanced CFD technology envisioned in } 2030 \text { is the way in which } \\
\text { the very large amount of CFD-generated data can be harvested and utilized to improve the overall } \\
\text { aerodynamic design and analysis process. }\end{array}$ \\
\hline & & $\begin{array}{l}\text { Editor: Data management is one of the areas not addressed much in this paper, but must be addressed } \\
\text { for EFD/CFD integration to proceed and to meet future development needs. More and more data is being } \\
\text { generated; what is needed and how it will be managed must be defined before each test (experimental, } \\
\text { computational, or both) campaign. Otherwise, unnecessary time and money will be spent and there is } \\
\text { significant risk that needed data will not have been acquired. }\end{array}$ \\
\hline Investment & 8 & $\begin{array}{l}\text {... one needs to invest in a capability before taking the promised gains. It is not uncommon in the DoD to } \\
\text { take the forecasted savings from M\&S up front usually by diminishing the resources for testing. The need } \\
\text { to invest in and implement the CSE tools to support the projected savings is usually not budgeted. As a } \\
\text { consequence, the modeling and the testing efforts in support of system development both come up short, } \\
\text { leading to further skepticism about M\&S in general. }\end{array}$ \\
\hline \multirow[t]{2}{*}{ Workforce } & \multirow[t]{2}{*}{19} & Need "data reductionists" and to design software to handle data. \\
\hline & & Editor: Must define the problem to know exactly what data is needed and potentially how to get it. \\
\hline \multirow[t]{2}{*}{ Strategic } & \multirow[t]{2}{*}{6} & Lack of explicit collaboration among turbulence researchers. \\
\hline & & $\begin{array}{l}\text { Editor: This may be a bit dated, as some efforts are ongoing; still, stovepipes driven by IP, costing, who } \\
\text { benefits, and other concerns persist. }\end{array}$ \\
\hline Strategic & 6 & $\begin{array}{l}\text { NASA should lead efforts to develop and execute integrated experimental testing and computational } \\
\text { validation campaigns. }\end{array}$ \\
\hline \multirow[t]{2}{*}{ Strategic } & \multirow[t]{2}{*}{19} & $\begin{array}{l}\text { Need capabilities for both computationalists and aerodynamicists to understand each step of the process; } \\
\text { must not expect each participant to understand every detail of developing the information. }\end{array}$ \\
\hline & & $\begin{array}{l}\text { Editor: Need both specialists and generalists; also need to ensure some "generalists" are fluent to a fair } \\
\text { depth in both areas. }\end{array}$ \\
\hline Strategic & 19 & $\begin{array}{l}\text { Need to have people from both worlds (experimental and theory) available to the aerodynamicist. We } \\
\text { obtain much data from experiments, and orders of magnitude more from CFD. }\end{array}$ \\
\hline
\end{tabular}

\section{Future State}

\begin{tabular}{|c|c|c|}
\hline Group & $\begin{array}{c}\text { Doc } \\
\text { Ref \# }\end{array}$ & \multicolumn{1}{c|}{ Excerpted Material and Editorial Comments } \\
\hline Approach & 1 & $\begin{array}{l}\text { Some of the attributes required for upgrades to current facilities or for future test facilities include: } \\
\text { Ability to install and de-install test articles in minutes to support high-frequency, short-duration tests } \\
\text { focused in areas where primary uncertainties exist and to optimize use of design of experiments } \\
\text { (DOE). }\end{array}$ \\
\hline
\end{tabular}




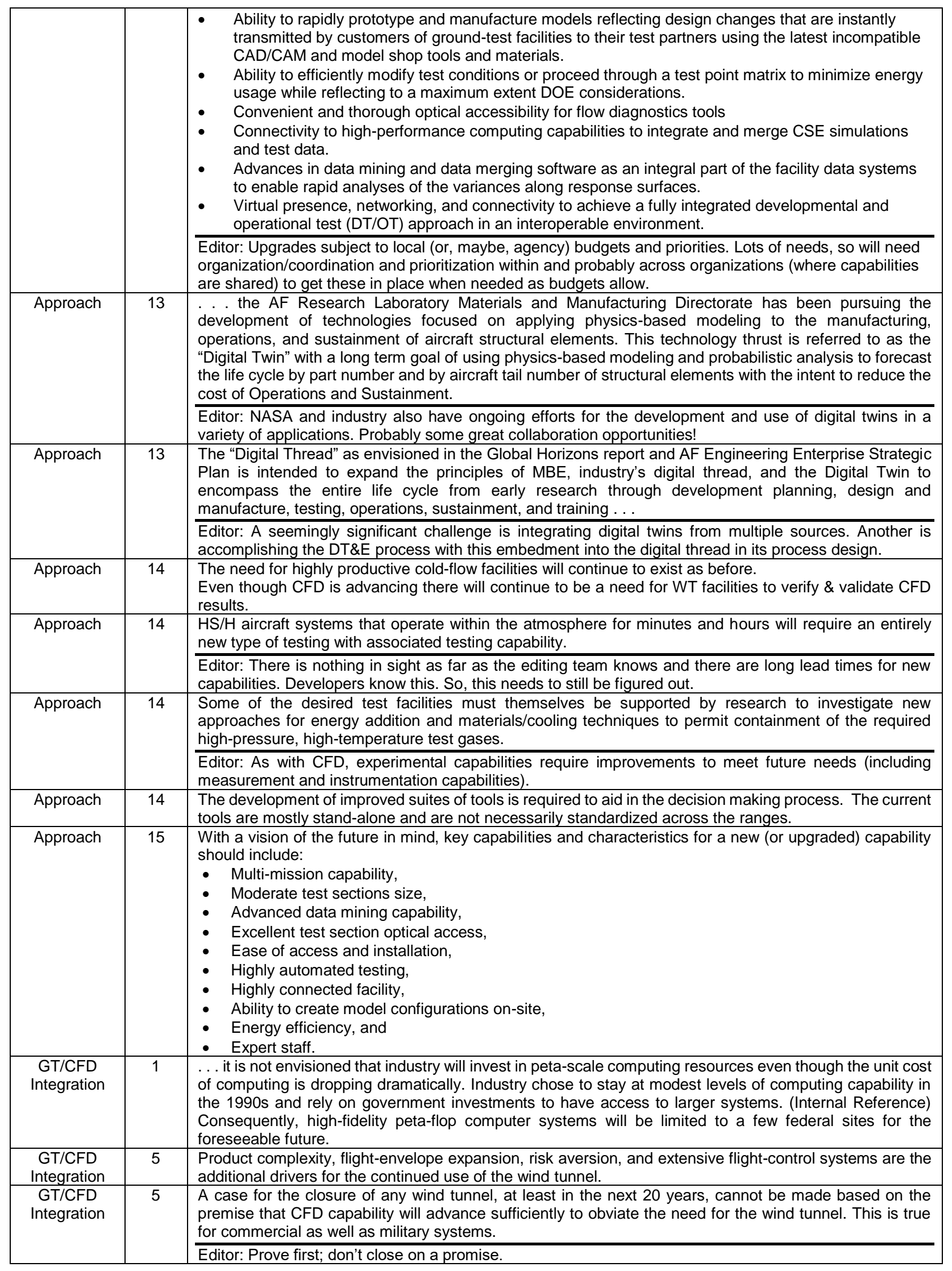




\begin{tabular}{|c|c|c|}
\hline \multirow[t]{2}{*}{$\begin{array}{l}\text { GT/CFD } \\
\text { Integration }\end{array}$} & \multirow[t]{2}{*}{5} & $\begin{array}{l}\text { Although computational fluid dynamics (CFD) is not expected to replace wind tunnels in the next } 20 \text { years, } \\
\text { the continued improvement in computational capabilities in terms of physics modeling and the increase in } \\
\text { efficiency due to the availability of much faster computing hardware will facilitate the increased use of CFD } \\
\text { in the design of aerospace vehicles. }\end{array}$ \\
\hline & & Editor: Requires investment for improvement in both EFD and CFD. \\
\hline & 5 & $\begin{array}{l}\text { Engineering program managers will willingly adopt a CFD-based design process, depending on how well } \\
\text { CFD improves the process in four general areas: } \\
\text { - Quality (accuracy) } \\
\text { - } \quad \text { Schedule (time) } \\
\text { - } \quad \text { Cost } \\
\text { - }\end{array}$ \\
\hline \multirow[t]{2}{*}{$\begin{array}{l}\text { GT/CFD } \\
\text { Integration }\end{array}$} & \multirow[t]{2}{*}{5} & $\begin{array}{l}\text { Except for flight-certification issues, CFD will soon be ready to replace wind tunnels for the attached-flow } \\
\text { cruise conditions. }\end{array}$ \\
\hline & & Editor: Progress has been made to certify by (WT) test or certify by CFD for derivative or similar designs. \\
\hline \multirow[t]{2}{*}{$\begin{array}{l}\text { GT/CFD } \\
\text { Integration }\end{array}$} & \multirow[t]{2}{*}{5} & \multirow{2}{*}{$\begin{array}{l}\text { risk that must be resolved in flight or the abandonment of potentially good concepts that entail too much } \\
\text { unresolved risk. } \\
\text { Editor: It's about best value risk management based on the state of the particular system in development. } \\
\text { The obvious goal is to catch major and most minor defects early. So, design a test campaign (EFD and } \\
\text { CFD) that best addresses needs (technical first, then schedule, then cost), which provides the best } \\
\text { outcome for all three at the system level. }\end{array}$} \\
\hline & & \\
\hline $\begin{array}{l}\text { GT/CFD } \\
\text { Integration }\end{array}$ & 5 & $\begin{array}{l}\text { Given the massive advances in computing that are expected, the question is not if but when CFD will } \\
\text { essentially replace nearly all wind-tunnel testing. This question will be faced by all aeronautical testing } \\
\text { facilities, if not in two decades, then in three to five decades. }\end{array}$ \\
\hline $\begin{array}{l}\text { GT/CFD } \\
\text { Integration }\end{array}$ & 5 & $\begin{array}{l}\text { The use of CFD for early concept development and phenomena investigation complements the use of } \\
\text { experiments for gathering the large volume of data that are needed to develop any significant product. }\end{array}$ \\
\hline $\begin{array}{l}\text { GT/CFD } \\
\text { Integration }\end{array}$ & 5 & $\begin{array}{l}\text { This study concludes that, based on current and projected machine shortfalls with respect to turbulence in } \\
\text { complex separated flows, wind tunnels will still be required; in fact, additional wind-tunnel testing will be } \\
\text { required both to adequately foster the development of appropriate turbulence models and to subsequently } \\
\text { build confidence in these models. }\end{array}$ \\
\hline $\begin{array}{l}\text { GT/CFD } \\
\text { Integration }\end{array}$ & 5 & $\begin{array}{l}\text { Useful quantum computing is projected to be possible in a couple of decades. The availability of quantum } \\
\text { computing would obviate the need for most physical testing, including the use of wind tunnels. }\end{array}$ \\
\hline $\begin{array}{l}\text { GT/CFD } \\
\text { Integration }\end{array}$ & 5 & $\begin{array}{l}\text {... CFD computations can be made fast enough to soon replace wind tunnels for aero-database generation } \\
\text { for aircraft cruise design. While no flow physics issues will likely require the use of wind tunnels for this } \\
\text { flow regime, flight certification procedures will have to be changed to eliminate the need for wind tunnels } \\
\text { in the cruise design. }\end{array}$ \\
\hline $\begin{array}{l}\text { GT/CFD } \\
\text { Integration }\end{array}$ & 8 & $\begin{array}{l}\text { The integration of multidisciplinary data is key to developing this aggressive approach to minimizing data } \\
\text { requirements. }\end{array}$ \\
\hline $\begin{array}{l}\text { GT/CFD } \\
\text { Integration }\end{array}$ & $9 \mathrm{a}$ & $\begin{array}{l}\text { Although CFD has made inroads in reducing some empirical test simulation requirements, CFD will not } \\
\text { replace the need for test facilities for the foreseeable future. }\end{array}$ \\
\hline $\begin{array}{l}\text { GT/CFD } \\
\text { Integration }\end{array}$ & 11 & $\begin{array}{l}\text { The RDT\&E infrastructure of the future will routinely allow adaptive integration of physical and simulated } \\
\text { components... }\end{array}$ \\
\hline $\begin{array}{l}\text { GT/CFD } \\
\text { Integration }\end{array}$ & 15 & $\begin{array}{l}\text { Computational analysis, long touted to replace wind tunnel testing, continues to play an important and } \\
\text { synergistic role in the development of air vehicles, but currently cannot simulate all flight conditions and } \\
\text { cannot produce the large volume of data required. Computational modeling will not replace wind tunnel } \\
\text { testing in the foreseeable future. }\end{array}$ \\
\hline $\begin{array}{l}\text { GT/CFD } \\
\text { Integration }\end{array}$ & 15 & $\begin{array}{l}\text { Evolution of the aircraft design process will require a more integrated and streamlined design/analysis/test } \\
\text { process that requires careful and deliberate integration of computational tools with wind tunnel testing. } \\
\text { Developing skilled practitioners capable of using both tools effectively is a key. }\end{array}$ \\
\hline $\begin{array}{l}\text { GT/CFD } \\
\text { Integration }\end{array}$ & 16 & $\begin{array}{l}\text { Integration of CFD and Ground/Flight Testing (includes risk management during research and product } \\
\text { development); Re-engineering including: } \\
\text { - } \quad \text { Early integrated use of high-fidelity physics modeling } \\
\text { - } \quad \text { A complete reexamination of the system ground-test approaches } \\
\text { - Development of Improvement testing methodologies and process for scaling of ground testing. }\end{array}$ \\
\hline $\begin{array}{l}\text { GT/CFD } \\
\text { Integration }\end{array}$ & 17 & $\begin{array}{l}\text { - Development of Improvement testing methodologies and process for scaling of ground testing. } \\
\text { addressing the evolution of analytical models, flexibility of the processes, and judicious consideration of } \\
\text { the data from previous tests and models. The systematic utilization of these information sources will allow } \\
\text { customers to benefit from a procedure that is seamless and easily used ... In order for this to occur, the } \\
\text { evolution of analytical models into flexible processes that enable the application of any of these models at } \\
\text { any point in the system development is needed. }\end{array}$ \\
\hline & 18 & CFD will increasingly complement wind tunnel data acquisition requirements. \\
\hline Integration & & Editor: "Complement" and integrate. \\
\hline $\begin{array}{l}\text { GT/CFD } \\
\text { Integration }\end{array}$ & 18 & $\begin{array}{l}\text { Wind tunnel testing's purpose is then to provide an anchor point with which to validate predictions or to } \\
\text { provide incremental corrections to existing designs instead of helping to drive the design. }\end{array}$ \\
\hline $\begin{array}{l}\text { GT/CFD } \\
\text { Integration }\end{array}$ & 18 & $\begin{array}{l}\text { More and more, test programs will consist of CFD simulations, coupled with wind tunnel testing in an } \\
\text { integrated fashion, to help reduce cost and shorten schedules. }\end{array}$ \\
\hline
\end{tabular}




\begin{tabular}{|c|c|c|}
\hline & & $\begin{array}{l}\text { Editor: Expectation caution - efficiencies have been getting outpaced by increasing complexities. A more } \\
\text { important outcome might be improved information quality resulting in better risk management. }\end{array}$ \\
\hline $\begin{array}{l}\text { GT/CFD } \\
\text { Integration }\end{array}$ & 18 & $\begin{array}{l}\text { Within the aerospace community, wind tunnel testing will continue to be utilized to validate predictions, } \\
\text { populate databases, and provide an anchor point for baseline concepts. }\end{array}$ \\
\hline \multirow[t]{2}{*}{$\begin{array}{l}\text { GT/CFD } \\
\text { Integration }\end{array}$} & \multirow[t]{2}{*}{19} & $\begin{array}{l}\text { CFD } 2030 \text { predicts that turbulence modeling can't be mastered in the next } 20 \text { to } 30 \text { years when computers } \\
\text { are expected to become more capable. }\end{array}$ \\
\hline & & $\begin{array}{l}\text { Editor: To include software tools, integrated CFD/EFD tools and measurements, improved gridding, and } \\
\text { the people making the inputs. }\end{array}$ \\
\hline Efficiency & 15 & $\begin{array}{l}\text { While test efficiency has increased significantly, the need to maintain a robust capability for effective wind } \\
\text { tunnel testing will continue well into the } 21 \text { st century. It is anticipated that new air vehicle programs } \\
\text { (however few) will continue to require volumes of data and wind tunnel tests will remain the primary source } \\
\text { for much of the data. }\end{array}$ \\
\hline \multirow[t]{2}{*}{ Efficiency } & \multirow[t]{2}{*}{18} & $\begin{array}{l}\text { High-speed machining coupled with ever improving CAD design capabilities will be another important } \\
\text { contributor to future reductions in model span time and cost. }\end{array}$ \\
\hline & & Editor: Additive manufacturing will have a similar impact. \\
\hline Sustainment & 15 & $\begin{array}{l}\text { Development, investment, and maintenance of wind tunnel infrastructure occur over a very long period of } \\
\text { time, greatly exceeding the ability to predict the actual "need" for the capability and capacity. }\end{array}$ \\
\hline \multirow[t]{2}{*}{ Sustainment } & \multirow[t]{2}{*}{18} & "Maintenance and improvement of key test assets is a vital component of enabling future test capabilities." \\
\hline & & Editor: Key point. \\
\hline \multirow[t]{2}{*}{ Investment } & \multirow[t]{2}{*}{1} & $\begin{array}{l}\text { Furthermore, older facilities will eventually reach a point where they become too costly to sustain and } \\
\text { upgrade, and building new construction is more cost effective. }\end{array}$ \\
\hline & & $\begin{array}{l}\text { Editor: The same will also hold true for CFD computing power requiring continuous upgrades / replacement } \\
\text { on a much shorter time scale. }\end{array}$ \\
\hline \multirow[t]{2}{*}{ Investment } & \multirow[t]{2}{*}{14} & $\begin{array}{l}\text { A proposed solution would look at redesigning how data are "encrypted" to meet security standards. Raw } \\
\text { unannotated/nondescriptive data are unclassified. Unless the parameter name and scale factor to apply } \\
\text { to each measurement are known, the data cannot be comprised. }\end{array}$ \\
\hline & & Editor: Data security is a key issue; not addressed in this paper. \\
\hline \multirow[t]{2}{*}{ Investment } & \multirow[t]{2}{*}{14} & $\begin{array}{l}\text { A proposed solution would need to determine the feasibility of nonintrusive instruments to measure } \\
\text { products of combustion and/or velocity, as well as set up a feasibility study of more advanced nonintrusive } \\
\text { instruments to measure in-stream products of combustion and/or velocities. }\end{array}$ \\
\hline & & $\begin{array}{l}\text { Editor: The entire area of instrumentation and measurement is beyond the scope of this paper and requires } \\
\text { its own study. }\end{array}$ \\
\hline Investment & 15 & $\begin{array}{l}\text { With a vision of the future in mind, key capabilities and characteristics for a new (or upgraded) capability } \\
\text { should include: } \\
\text { - Multi-mission capability. } \\
\text { - } \quad \text { Moderate Test sections size } \\
\text { - } \quad \text { Advanced data capability } \\
\text { - } \quad \text { ancellent test section optical access for application of developing on- and off-body flow visualization } \\
\text { - } \quad \text { Ease of access and installation. } \\
\text { - Highly automated testing. } \\
\text { - } \quad \text { Highly connected facility. } \\
\text { - } \quad \text { Enility to create model configurations on-site. } \\
\text { - } \quad \text { Expert staff }\end{array}$ \\
\hline Investment & 18 & "Maintenance and improvement of key test assets is a vital component of enabling future test capabilities." \\
\hline \multirow[t]{2}{*}{ Investment } & \multirow[t]{2}{*}{18} & "New high-speed test infrastructure is required to meet anticipated requirements for future systems." \\
\hline & & $\begin{array}{l}\text { Editor: As the time to field a new design decreases, in some cases limited life span attritable aircraft } \\
\text { (UAVs), the entire aerospace industry will have to adapt to a new rapid pace benchmark. }\end{array}$ \\
\hline Investment & 18 & $\begin{array}{l}\text { What capabilities will be needed and how will they need to work and be managed? } \\
\text { - } \quad \text { Anchor point limited wind tunnel test } \\
\text { - } \quad \text { Inta mining and Real time quantitative and visualization of on and off body flow fields. } \\
\text { - } \quad \text { W/T would need large speed ranges with flow visualization at any speed, adaptable to various types } \\
\text { of testing and be highly automated to reduce the need for model changes. }\end{array}$ \\
\hline \multirow[t]{2}{*}{ Investment } & \multirow[t]{2}{*}{19} & $\begin{array}{l}\text { A large-scale (16-ft square test section) (AEDC/16S) supersonic (hypersonic?) wind tunnel testing } \\
\text { capability is needed for the development of expanded missile defense vehicles. }\end{array}$ \\
\hline & & $\begin{array}{l}\text { Editor: AEDC has started to reinvest in } 16 \mathrm{~S} \text {. IOC to a defined level of capability (specifics not known to } \\
\text { the authors) is planned for FY19. Note that previous study indicates that } 16 \mathrm{~S} \text { appears feasible to operate } \\
\text { up to Mach } 6 \text {, making it a } 16 \text {-ft hypersonic tunnel }(16 \mathrm{H}) .^{27}\end{array}$ \\
\hline Workforce & 15 & $\begin{array}{l}\text { Predicting accurately the future wind tunnel test requirements, both in terms of capability and capacity, is } \\
\text { difficult; but historical data trends indicate a strong need to maintain significant wind tunnel test expertise } \\
\text { and capability. }\end{array}$ \\
\hline
\end{tabular}




\begin{tabular}{|c|c|c|}
\hline Workforce & 17 & $\begin{array}{l}\text { The role of the analyst and test team is multifold. The team must be available and readily accessible to } \\
\text { offer the customer system evaluation support at any time and/or phase of the acquisition process. This } \\
\text { support is needed from concept exploration through the operational use of the developed systems. }\end{array}$ \\
\hline Workforce & 17 & $\begin{array}{l}\text {... today's T\&E professionals must continue to pursue many processes with continued vigor. Continued } \\
\text { test planning, matrix optimization, and pretest predictions will be an ongoing focus. Online data analysis, } \\
\text { data validation, and real-time matrix modifications will continue to be refined. This will be coupled with } \\
\text { posttest data evaluation and the integration of data with analytical models for increased accuracy and } \\
\text { efficiency. Increased interaction between ground simulation and flight test protocols will aid continued } \\
\text { improvements in test planning support as well as pretest predictions. At the end of testing, posttest analysis } \\
\text { and the systematic investigation of anomalies will further the accuracy of the testing process. }\end{array}$ \\
\hline Workforce & 18 & Development of a knowledgeable test workforce is critical for the national infrastructure. \\
\hline \multirow[t]{2}{*}{ Strategic } & \multirow[t]{2}{*}{5} & $\begin{array}{l}\text { A case for the closure of any wind tunnel, at least in the next } 20 \text { years, cannot be made based on the } \\
\text { premise that CFD capability will advance sufficiently to obviate the need for the wind tunnel. This is true } \\
\text { for commercial as well as military systems. }\end{array}$ \\
\hline & & Editor: Again, readiness must be proven to some defined level and closure not based on a promise. \\
\hline Strategic & $9 a$ & $\begin{array}{l}\text { Anticipated strategic needs include the following: } \\
\text { - } \quad \text { Space access - subsonic through hypersonic speeds and recent efforts for air-breathing } \\
\text { hypersonic propulsion. } \\
\text { - } \quad \text { Commercial transports - subsonic through supersonic and their propulsion systems. } \\
\text { - } \quad \text { Military vehicles - subsonic through supersonic vehicles and their propulsion systems. } \\
\text { Military weapons - supersonic through hypersonic missiles and their propulsion systems. }\end{array}$ \\
\hline \multirow[t]{2}{*}{ Strategic } & \multirow[t]{2}{*}{$9 a$} & $\begin{array}{l}\text { No vehicle classes have been eliminated from future needs, and each class will continue to require } \\
\text { empirical prediction of airflow behavior across a range of design considerations. Even beyond the existing } \\
\text { programs, it is clear that the country will eventually need to produce each existing vehicle class. }\end{array}$ \\
\hline & & $\begin{array}{l}\text { Editor: Important point when trying to figure out what to close. Conops for EFD is changing with advancing } \\
\text { CFD capabilities. Decisions must be made based on risk management for the development of new vehicles } \\
\text { across the class ranges. }\end{array}$ \\
\hline \multirow[t]{2}{*}{ Strategic } & \multirow[t]{2}{*}{$9 \mathrm{~b}$} & $\begin{array}{l}\text { The facilities most detrimental to close would affect any strategic national need from all sectors-NASA } \\
\text { research, civil aviation, military, and space-not just NASA research needs. }\end{array}$ \\
\hline & & Editor: NASA research supports many national needs. \\
\hline Strategic & $9 \mathrm{~b}$ & $\begin{array}{l}\text { Thus, the aeronautics prediction capabilities required to produce these vehicles (no matter their production } \\
\text { rate) must be preserved or be able to be regenerated in a timely manner, or the country will risk losing the } \\
\text { ability to produce them without dependency on foreign cooperation and access to their test capabilities. }\end{array}$ \\
\hline Strategic & 10 & $\begin{array}{l}\text {... the R\&D goals and objectives will require stable and long-term foundational research across a breadth } \\
\text { of aeronautics disciplines to provide the underlying basis for new technological advances and } \\
\text { breakthroughs. }\end{array}$ \\
\hline Strategic & 16 & $\begin{array}{l}\text { Development of an optimum integration of S\&T and T\&E capabilities for inserting new technologies into } \\
\text { acquisition development programs should result in: } \\
\text { - A reduction in the potential risk of inserting an immature technology into an Air Force acquisition } \\
\text { program resulting in much less overrun in the RDT\&E costs and cutting cycle time by reducing the } \\
\text { number of late defect discoveries } \\
\text { - } \quad \text { Delivery of more war fighting capability for a given budget } \\
\text { - } \quad \text { Production of significant dividends for future recapitalization of the Air Force } \\
\text { - } \quad \text { Acceleration of the maturation of critical technologies for war fighting capabilities } \\
\text { - Better utilization and sustainment of T\&E capabilities. }\end{array}$ \\
\hline \multirow[t]{2}{*}{ Strategic } & \multirow[t]{2}{*}{18} & $\begin{array}{l}\text { Divestment of redundant and nonessential test infrastructure is required to focus limited resources on } \\
\text { critical capabilities and new infrastructure requirements. }\end{array}$ \\
\hline & & $\begin{array}{l}\text { Editor: See above statement (vehicle classes). Limited funds is a function of choices. Closing obsolete or } \\
\text { unneeded infrastructure is necessary, as long as the decisions are based on system level needs. }\end{array}$ \\
\hline Strategic & 18 & $\begin{array}{l}\text { The most ideal future scenario will include highly integrated computational and physical simulation capable } \\
\text { of rapid evaluation of concepts and configurations. Robust and reliable CFD modeling simulation will be } \\
\text { used to evaluate and narrow the design options to a chosen few. Rapid wind tunnel model design and } \\
\text { fabrication would begin taking advantage of light-weight, easily workable, and high-strength materials to } \\
\text { manufacture modularized model parts for testing. Wind tunnels would be readily available with capabilities } \\
\text { spanning a large speed range and flow visualization at any speed, efficient data gathering process } \\
\text { (hardware and software), automation that reduces model changes, and adaptable to various types of } \\
\text { testing, i.e., aero, propulsion, loads, and noise. Entries in the tunnel will be shorter and more rapid, } \\
\text { providing focused physical validation of analytic estimates and, where appropriate, volumes of data } \\
\text { required for extensive control law and flight envelope expansion. }\end{array}$ \\
\hline Strategic & 19 & $\begin{array}{l}\text { The value of wind tunnels for weapon systems should be measured by the quality of flight systems we can } \\
\text { produce rather than cost. }\end{array}$ \\
\hline \multirow[t]{2}{*}{ Programmatic } & \multirow[t]{2}{*}{5} & $\begin{array}{l}\ldots \text { we must note that during the stated time period (i.e., } 20 \text { years) only a few new commercial airplanes } \\
\text { will be developed. In the absence of a major aeronautics initiative, these new airplanes will be expected to } \\
\text { adhere to essentially the same basic design paradigm that presently exists. }\end{array}$ \\
\hline & & Editor: How will new breakthroughs happen? \\
\hline Programmatic & 14 & $\begin{array}{l}\text { Over-land flight capability is critical for the viability of future } \mathrm{HS} / \mathrm{H} \text { testing and operations for military access } \\
\text { to space and hypersonic vehicles. }\end{array}$ \\
\hline
\end{tabular}




\begin{tabular}{|c|c|c|}
\hline Programmatic & 14 & $\begin{array}{l}\text { To fulfill the purpose of national space policy and national space transportation policy, suitable hypersonic } \\
\text { corridors for air-launched, generic, combined-cycle, and hypersonic vehicles need to be identified. } \\
\text { Editor: Important for hypersonic systems development. Again, this needs much more assessment and } \\
\text { attention beyond what this paper covers. }\end{array}$ \\
\hline Programmatic & 15 & $\begin{array}{l}\text { Development of a new test capability, in today's world, would require approximately a twenty-year effort. } \\
\text { Acquisition of capital investment funds to accomplish significant maintenance and repair of existing } \\
\text { facilities can take upwards of ten years planning. Both of these span times far exceed the ability to } \\
\text { accurately predict the future "need" for test capabilities. } \\
\text { Editor: So, this approach not likely. What is another approach that can deliver a capability in a shorter } \\
\text { timespan for less cost? Or do without. }\end{array}$ \\
\hline Programmatic & 18 & $\begin{array}{l}\text { "Divestment of redundant and nonessential test infrastructure is required to focus limited resources on } \\
\text { critical capabilities and new infrastructure requirements." }\end{array}$ \\
\hline \multirow[t]{2}{*}{ Programmatic } & \multirow[t]{2}{*}{18} & $\begin{array}{l}\text { As wind tunnel facilities and capabilities decrease and test costs almost certainly increase, } \\
\text { a. programs become forced to choose between accepting increased vehicle development risk through } \\
\text { b. limited testing, } \\
\text { c. forgoing testing altogether and committing to full dependency on computational modeling. }\end{array}$ \\
\hline & & Editor: Or quit. \\
\hline \multirow[t]{2}{*}{$\begin{array}{c}\text { Systems } \\
\text { Integration }\end{array}$} & \multirow[t]{2}{*}{1} & $\begin{array}{l}\text { Most defects occur at the interface of major subsystems. Current practices generally address system } \\
\text { integration issues later in the development process which maximizes the amount of rework required (and } \\
\text { increases associated costs) if a defect is discovered. }\end{array}$ \\
\hline & & Editor: Needs clarifying comment Foot stomper! \\
\hline \multirow[t]{2}{*}{$\begin{array}{l}\text { Systems } \\
\text { Integration }\end{array}$} & \multirow[t]{2}{*}{5} & $\begin{array}{l}\text { For aircraft manufacturers, the target is to reduce the aircraft development process to one design cycle. } \\
\text { This will require significant improvements in both CFD and wind tunnels... The alternative is more risk that } \\
\text { must be resolved in flight or the abandonment of potentially good concepts that entail too much unresolved } \\
\text { risk. }\end{array}$ \\
\hline & & $\begin{array}{l}\text { Editor: Strong push to accomplish certification by analysis - integrates with earlier development, reducing } \\
\text { time and cost for flight testing. Requires a new risk management paradigm and associated assessment } \\
\text { and proof. }\end{array}$ \\
\hline \multirow[t]{2}{*}{$\begin{array}{c}\text { Systems } \\
\text { Integration }\end{array}$} & \multirow[t]{2}{*}{$9 a$} & $\begin{array}{l}\text { Because of high costs and instrumentation limitations, flight testing complements but does not replace } \\
\text { WT/PT facilities. }\end{array}$ \\
\hline & & Editor: Integration with flight testing \\
\hline $\begin{array}{l}\text { Systems } \\
\text { Integration }\end{array}$ & 11 & $\begin{array}{l}\text { The RDT\&E infrastructure of the future will routinely allow adaptive integration of physical and simulated } \\
\text { components, dynamically creating geographically distributed real-time systems of systems. }\end{array}$ \\
\hline $\begin{array}{l}\text { Systems } \\
\text { Integration }\end{array}$ & 17 & $\begin{array}{l}\text {. . the application of multidisciplined computational methods and powerful computing capabilities, in } \\
\text { concert with a ground testing and flight testing IT\&E approach, will make it possible to simulate and } \\
\text { evaluate the aerodynamics, aeroacoustics, structural response, heat-transfer characteristics, store } \\
\text { separation qualities, and electromagnetic, or stealth, characteristics of a vehicle prior to flight. }\end{array}$ \\
\hline
\end{tabular}

\section{E. Gaps}

\begin{tabular}{|c|c|c|}
\hline Group & $\begin{array}{l}\text { Doc } \\
\text { Ref \# }\end{array}$ & Excerpted Material and Editorial Comments \\
\hline Approach & 1 & $\begin{array}{l}\text { An area where scaling effects are not well understood and CSE may have the potential for producing new } \\
\text { insights is simulation of military tactical aircraft at high-angle maneuvering conditions. }\end{array}$ \\
\hline Approach & 1 & $\begin{array}{l}\text { CSE can be an invaluable tool to ensure better use of ground-test facilities to preclude design defects from } \\
\text { finding their way into the flight-test program } \\
\text { Editor: CSE is complementary to GT facilities in detecting desian defects early in the development process. }\end{array}$ \\
\hline Approach & 5 & $\begin{array}{l}\text {... accounting for certain effects, such as the influence of free-stream disturbances through their effect on } \\
\text { transition, is not possible }\end{array}$ \\
\hline Approach & 5 & These scaling issues can in turn be influenced by other flight-to-wind-tunnel differences \\
\hline Approach & 5 & $\begin{array}{l}\text { Wind-Tunnel-to-Flight Scaling Issues } \\
\text { 1. Wind tunnel walls: solid, porous/slotted, adaptive, open jet. } \\
\text { 2. Aeroelastic distortion differences: specific wind-tunnel/model conditions versus flight. } \\
\text { 3. Sufficient Reynolds number scaling: especially critical for transonic flows, longitudinal vortices, large } \\
\text { transitional flow influences (separation, hypersonics). } \\
\text { 4. Stream disturbance fields: vorticity dynamics, acoustics, entropy spottiness, particulates, and, } \\
\text { especially, influence(s) on transition. } \\
\text { 5. Model mounting influences: sting, strut, wire (e.g., rear, side). } \\
\text { 6. Stream gross unsteadiness, of special concern for buffet. } \\
\text { 7. Installed propulsion influences or lack thereof: various propulsion simulators/effects. } \\
\text { 8. Geometric fidelity: potential criticality of even minor differences in flight to ground, including } \\
\text { curvatures and second derivatives, difficulties in scaling small features, boundary-layer tripping, and } \\
\text { 9. Strip drag. } \\
\text { 10. Leakage/spillage/efflux differences. }\end{array}$ \\
\hline
\end{tabular}




\begin{tabular}{|c|c|c|}
\hline & & $\begin{array}{l}\text { 11. Wall-to-total-temperature ratio, humidity. } \\
\text { 12. Differences flight to ground in instrumentation details (i.e., nature, locations, and accuracy), } \\
\text { including variability of the various/multitudinous transition detection schemes and approaches, and } \\
\text { data-reduction errors. } \\
\text { 13. High-energy, high-density effects for hypersonics. }\end{array}$ \\
\hline Approach & 10 & $\begin{array}{l}\text { Foundational research provides the "building blocks" of a technology base to successfully address the } \\
\text { stated goals and objectives. }\end{array}$ \\
\hline \multirow[t]{2}{*}{ Approach } & \multirow[t]{2}{*}{13} & The mathematics of the DOE methodology helps assure the optimum data set is taken \\
\hline & & $\begin{array}{l}\text { Editor: The approach to using DOE within experimental test facilities must be optimized based on that } \\
\text { facility's performance characteristics. DOE provides } 95 \% \text { confidence level for the development of the } \\
\text { database, while OFAT may be more susceptible to bias and uncertainty errors - this can be a trade-off } \\
\text { with the time each version can take. }\end{array}$ \\
\hline Approach & 14 & ... some shortfalls exist in our range infrastructure to adequately validate their applicable technologies \\
\hline Approach & 14 & A flight-test gap exists in the capability to air-launch the heavier hypersonic missile systems. \\
\hline Approach & 14 & $\begin{array}{l}\text { Also, there is not a capability to propulsion mode transition testing at supersonic and hypersonic Mach } \\
\text { numbers. }\end{array}$ \\
\hline \multirow[t]{2}{*}{ Approach } & \multirow[t]{2}{*}{14} & $\begin{array}{l}\text { Although short run times may be useful for evaluating performance at discrete design points, seconds, } \\
\text { minutes, or tens of minutes of run time will be required for operability and durability testing. }\end{array}$ \\
\hline & & $\begin{array}{l}\text { Editor: Part of the reason they are short duration facilities is the models can't survive the long duration } \\
\text { environment. }\end{array}$ \\
\hline \multirow[t]{2}{*}{ Approach } & \multirow[t]{2}{*}{14} & At present, aero-optic testing is limited to cold-flow (perfect gas) and impulse wind tunnels. \\
\hline & & $\begin{array}{l}\text { Editor: The LENS XX Expansion Tunnel was designed and constructed by CUBRC to provide a research } \\
\text { and testing capability to investigate real gas, shock layer chemistry, viscous interaction and ablation effects } \\
\text { on the performance of hypervelocity vehicles. LENS XX generates clean uncontaminated high enthalpy } \\
\text { flows at velocities up to } 35,000 \mathrm{ft} / \mathrm{sec} \text { to simulate re-entry into Earth and other planetary atmospheres. At } \\
100 \text { 's of milliseconds, the LENS facilities are actually short duration rather than impulse. }\end{array}$ \\
\hline \multirow[t]{2}{*}{ Approach } & \multirow[t]{2}{*}{14} & $\begin{array}{l}\text { Developers of missiles favor a full-scale test in highly productive facilities and will acquiesce to flight } \\
\text { duplication enthalpies that can be provided only by very short run time facilities (shock/impulse wind } \\
\text { tunnels). }\end{array}$ \\
\hline & & $\begin{array}{l}\text { Editor: Agreed. S\&C database data is required for flight control systems programming. More } \\
\text { maneuverability means more data is needed. }\end{array}$ \\
\hline Approach & 14 & $\begin{array}{l}\text { Development of a programmed accelerating and decelerating hypersonic propulsion system is considered } \\
\text { to be a challenge for both the engine designer and the test facility designer. }\end{array}$ \\
\hline \multirow[t]{2}{*}{ Approach } & \multirow[t]{2}{*}{14} & $\begin{array}{l}\text { Existing ground-test facilities can provide partial simulation. Perfect gas wind tunnels are used to measure } \\
\text { heat-transfer coefficients (up to about Mach 16) although they do not provide the enthalpy required for the } \\
\text { full heating rates. Impulse tunnels can provide the correct Mach number and enthalpy but for very short } \\
\text { test times. }\end{array}$ \\
\hline & & $\begin{array}{l}\text { Editor: LENS can evaluate correctly duplicated real gas chemistry effects upwards of Mach } 20 \text { for Matching } \\
\text { altitude velocity, velocity conditions up to } 10 \mathrm{~km} / \mathrm{sec} \text { are now possible as well to further study these effects }\end{array}$ \\
\hline Approach & 14 & $\begin{array}{l}\text { Gaps between current capabilities and required capabilities were the basis for determining a HS/H T\&E } \\
\text { capability requirement roadmap. }\end{array}$ \\
\hline Approach & 14 & $\begin{array}{l}\text { It will be necessary to test major full-scale aircraft components in non-flow ground-test facilities that } \\
\text { produce both external and internal loading. }\end{array}$ \\
\hline \multirow[t]{2}{*}{ Approach } & \multirow[t]{2}{*}{14} & $\begin{array}{l}\text { Reasonably good hypersonic perfect gas aerodynamic wind tunnels exist today, but none simulate the } \\
\text { real-gas and aerothermal effects encountered in flight at Mach numbers above } 8 \text {. }\end{array}$ \\
\hline & & Editor: See note above regarding LENS. \\
\hline Approach & 14 & $\begin{array}{l}\text { Several of the off-ramp vehicles change propulsive mode as they accelerate or decelerate This propulsion } \\
\text { concept is a requirement for all hypersonic vehicles that operate throughout the flight envelope from takeoff } \\
\text { to cruise. }\end{array}$ \\
\hline \multirow[t]{2}{*}{ Approach } & \multirow[t]{2}{*}{14} & $\begin{array}{l}\text { The aerothermal environment is composed of the aerodynamics, the enthalpy (or velocity), and the density } \\
\text { effects. Around Mach } 8 \text { to } 10 \text { in the air-breathing propulsion flight corridor, air will begin to chemically } \\
\text { dissociate (oxygen initially) when passing through the initial shock system produced by the vehicle. At } \\
\text { Mach numbers greater than } 12 \text {, the gases begin to ionize. Dissociation and recombination can continue to } \\
\text { occur in the flow boundary layer resulting in significant effects on the vehicle heating. . Existing ground- } \\
\text { test facilities can provide partial simulation. }\end{array}$ \\
\hline & & $\begin{array}{l}\text { Editor: At Mach numbers greater than } 12 \text {, the gases begin to ionize. Dissociation and recombination can } \\
\text { continue to occur in the flow boundary layer resulting in significant effects on the vehicle heating. Existing } \\
\text { ground-test facilities can provide partial simulation; see above note regarding LENS. }\end{array}$ \\
\hline \multirow[t]{2}{*}{ Approach } & \multirow[t]{2}{*}{14} & $\begin{array}{l}\text { The effects and limitations of combustion-vitiated testing, development of clean air test facilities below } \\
\text { Mach } 8 \text {, definition of needed facility runs times, and definition/development of test capabilities above Mach } \\
8 \text { are all test facility technology gaps that must be addressed. }\end{array}$ \\
\hline & & $\begin{array}{l}\text { Editor: It was pointed out in a recent presentation at the Air Vehicles Tech } 2017 \text { symposium that it is highly } \\
\text { unlikely that new large test facilities will be built in the US. So, this gap may remain. }\end{array}$ \\
\hline Approach & 14 & $\begin{array}{l}\text { The large engine test facilities are limited to Mach 3.2, yet turbine engine R\&D programs predict future } \\
\text { engine performance to Mach } 4 \text { and above. }\end{array}$ \\
\hline
\end{tabular}




\begin{tabular}{|c|c|c|}
\hline & & $\begin{array}{l}\text { Editor: Efforts are underway to configure and validate facilities with higher capability. Will their completion } \\
\text { match a timeframe that industry would find productive? Currently, the NASA Glenn PSL- } 4 \text { facility is rated } \\
\text { to Mach } 4.0 .{ }^{26}\end{array}$ \\
\hline \multirow[t]{2}{*}{ Approach } & \multirow[t]{2}{*}{14} & There is a gap in the ability to cost-effectively recover expendable hypersonic vehicles for data analysis. \\
\hline & & $\begin{array}{l}\text { Editor: Some rocket-based vehicles are designed to be reusable and are being recovered. And concepts } \\
\text { are being developed for a hypersonic reusable testbed - but funding and action is in question. }\end{array}$ \\
\hline Approach & 14 & There is currently a gap in the capabilities for testing hardware in the loop. \\
\hline Approach & 16 & $\begin{array}{l}\text { Concomitant with the high-alpha study above, the same collaborative effort could help develop a database } \\
\text { for validation of the next generation of CFD codes. }\end{array}$ \\
\hline Approach & 16 & $\begin{array}{l}\text { Current wind tunnel scaling principles are based on circa } 1975 \text { studies of Reynolds Number scaling of } \\
\text { attached flows on transport configurations. }\end{array}$ \\
\hline Approach & 19 & $\begin{array}{l}\text { The strengths of ground testing (GT) are that its measurements are finite and its physics are well defined } \\
\text { and irrefutable, except that it's in a wind tunnel. }\end{array}$ \\
\hline \multirow[t]{2}{*}{ Approach } & \multirow[t]{2}{*}{19} & $\begin{array}{l}\text { We need [wind tunnel] models to enable us to treat flows inside scramjet engines as close to reality as } \\
\text { possible. }\end{array}$ \\
\hline & & Editor: Does this mean we need tunnels that can accommodate hot gas and full scale (flight hardware)? \\
\hline $\begin{array}{l}\text { GT/CFD } \\
\text { Integration }\end{array}$ & 1 & $\begin{array}{l}\text { At the same time computer systems have advanced, so has the complexity of aeronautical systems... } \\
\text { made it more challenging to model the physics of military flight systems. }\end{array}$ \\
\hline $\begin{array}{l}\text { GT/CFD } \\
\text { Integration }\end{array}$ & 5 & $\begin{array}{l}\text { The bulk, if not all, of the CFD is based on nonlinear methods including full potential with coupled boundary } \\
\text { layer, Euler, and RANS. To be able to expand the use of CFD over the entire flight envelope, considerable } \\
\text { progress in algorithm, physics modeling, and hardware technology is still necessary. }\end{array}$ \\
\hline $\begin{array}{l}\text { GT/CFD } \\
\text { Integration }\end{array}$ & 5 & $\begin{array}{l}\text { CFD data can be used to determine initial structural sizing, to support wing trade studies, and to help scale } \\
\text { the wind-tunnel database to flight conditions. However, CFD is not yet able to deliver the required degree } \\
\text { of accuracy (low single-digit percentages over a wide range of conditions) and the throughput that is } \\
\text { necessary to replace extensive wind-tunnel testing. }\end{array}$ \\
\hline $\begin{array}{l}\text { GT/CFD } \\
\text { Integration }\end{array}$ & 5 & $\begin{array}{l}\text { For aircraft manufacturers, the target is to reduce the aircraft development process to one design cycle. } \\
\text { This will require significant improvements in both CFD and wind tunnels. For example, new design } \\
\text { concepts are driving the need for higher Reynolds number testing, and the productivity of existing } \\
\text { cryogenic, high-Reynolds-number wind tunnels needs to be improved by at least an OOM (order of } \\
\text { magnitude). The alternative is more risk that must be resolved in flight or the abandonment of potentially } \\
\text { good concepts that entail too much unresolved risk. Current CFD technology cannot mitigate this risk. }\end{array}$ \\
\hline $\begin{array}{l}\text { GT/CFD } \\
\text { Integration }\end{array}$ & 5 & $\begin{array}{l}\text { The inability to capture these differences adequately is a problem for both CFD and typical low-Reynolds- } \\
\text { number wind-tunnel testing. }\end{array}$ \\
\hline $\begin{array}{l}\text { GT/CFD } \\
\text { Integration }\end{array}$ & 5 & $\begin{array}{l}\text { The lack of robust, accurate prediction methods for aerodynamic S\&C was cited as a major shortcoming } \\
\text { in the available design methodology. One of the conclusions that was reached at this workshop was, } \\
\text { "Prediction of the onset of separated flows across the speed range (with the attendant issues of transition } \\
\text { prediction, turbulence modeling, unsteady flows, etc.), and the character and impact of separated flow on } \\
\text { aircraft capabilities, is the single most critical fundamental issue to be addressed and should receive a very } \\
\text { high priority in aerodynamic R\&D programs." }\end{array}$ \\
\hline $\begin{array}{l}\text { GT/CFD } \\
\text { Integration }\end{array}$ & 5 & $\begin{array}{l}\text { The well-recognized challenges for CFD technology include: } \\
\text { - } \quad \text { Aeroelastic distortion } \\
\text { - } \quad \text { Boundary conditions (e.g., wind-tunnel walls, stings, and in-flight boundary conditions for higher } \\
\text { fidelity simulations) } \\
\text { - } \quad \text { Turbulence modeling (e.g., formulations, variable constants, gross shortfalls in capability) } \\
\text { - } \quad \text { Predictions for drag (which are far less accurate than those for lift) } \\
\text { - } \quad \text { Bntrustworthy" results near the outer portions of the flight envelope } \\
\text { - } \quad \text { Discretization errors } \\
\text { - } \quad \text { Mismatches in (macro and micro) geometry, computation-to-experiment and application. }\end{array}$ \\
\hline $\begin{array}{l}\text { GT/CFD } \\
\text { Integration }\end{array}$ & 5 & $\begin{array}{l}\text { While low speed (e.g., takeoff/landing) is a problem for CFD, supersonic speed is even more difficult } \\
\text { because of the strong shock-boundary-layer interactions, and hypersonic speed is probably the most } \\
\text { difficult of all because of the critical roles of boundary-layer transition, heat transfer, and chemical reaction. }\end{array}$ \\
\hline $\begin{array}{l}\text { GT/CFD } \\
\text { Integration }\end{array}$ & 6 & $\begin{array}{l}\text { Perhaps the single, most critical area in CFD simulation capability that will remain a pacing item by } 2030 \\
\text { in the analysis and design of aerospace systems is the ability to adequately predict viscous turbulent flows } \\
\text { with possible boundary layer transition and flow separation present. }\end{array}$ \\
\hline $\begin{array}{l}\text { GT/CFD } \\
\text { Integration }\end{array}$ & 6 & $\begin{array}{l}\text { Multi-Disciplinary/Multi-Physics Simulations and Frameworks. We also assume that CFD capabilities in } \\
2030 \text { will play a significant role in routine, multi-disciplinary analysis (MDA) and optimization (MDAO) that } \\
\text { will be typical of engineering and scientific practice. In fact, in } 2030 \text { many of the aerospace engineering } \\
\text { problems of interest will be of a multi-disciplinary nature and CFD will have to interface seamlessly with } \\
\text { other high-fidelity analyses including acoustics, structures, heat transfer, reacting flow, radiation, dynamics } \\
\& \text { control, and even ablation and catalytic reactions in thermal protection systems. }\end{array}$ \\
\hline $\begin{array}{l}\text { GT/CFD } \\
\text { Integration }\end{array}$ & 6 & $\begin{array}{l}\text { Unsteady Turbulent Flow Simulations Including Transition and Separation. Perhaps the single, most critical } \\
\text { area in CFD simulation capability that will remain a pacing item by } 2030 \text { in the analysis and design of } \\
\text { aerospace systems is the ability to adequately predict viscous turbulent flows with possible boundary layer } \\
\text { transition and flow separation present. }\end{array}$ \\
\hline $\begin{array}{l}\text { GT/CFD } \\
\text { Integration }\end{array}$ & 8 & $\begin{array}{l}\text { Turbulence modeling may be one of those intractable engineering problems that cannot be solved with } \\
\text { higher performance computing. }\end{array}$ \\
\hline
\end{tabular}




\begin{tabular}{|c|c|c|}
\hline $\begin{array}{l}\text { GT/CFD } \\
\text { Integration }\end{array}$ & $9 \mathrm{a}$ & $\begin{array}{l}\text { The technology is not yet considered reliable for predicting the characteristics of the complex separated } \\
\text { flows that dominate many critical design points for an aircraft. }\end{array}$ \\
\hline \multirow[t]{2}{*}{$\begin{array}{l}\text { GT/CFD } \\
\text { Integration }\end{array}$} & \multirow[t]{2}{*}{13} & $\begin{array}{l}\text { There is a point at which doing another CFD solution will not reduce uncertainty further; hence, one needs } \\
\text { to move on to wind tunnel testing. }\end{array}$ \\
\hline & & Editor: See uncertainty explanation statement in section II.A (above). \\
\hline \multirow[t]{2}{*}{$\begin{array}{l}\text { GT/CFD } \\
\text { Integration }\end{array}$} & \multirow[t]{2}{*}{16} & $\begin{array}{l}\text {... integrated use of advanced computational fluid dynamics (CFD) codes, modern design of experiments } \\
\text { (MDOE), and "fly the mission" testing techniques to reduce the overall test hours in a wind tunnel } \\
\text { "campaign". }\end{array}$ \\
\hline & & $\begin{array}{l}\text { Editor: This implies that CFD solutions are faster to obtain than WT campaigns. CFD would be (will } \\
\text { continue to be) costly and time consuming to fill an S\&C database. }\end{array}$ \\
\hline $\begin{array}{l}\text { GT/CFD } \\
\text { Integration }\end{array}$ & 18 & $\begin{array}{l}\ldots \text { it is the integration of these tools, in the hands of knowledgeable experts that ultimately will produce } \\
\text { the improvements required. }\end{array}$ \\
\hline $\begin{array}{l}\text { GT/CFD } \\
\text { Integration }\end{array}$ & 18 & A key challenge has been integrating computational simulation and experimental efforts. \\
\hline \multirow{2}{*}{$\begin{array}{l}\text { GT/CFD } \\
\text { Integration }\end{array}$} & \multirow[t]{2}{*}{19} & ... some test facilities cannot replicate the turbulence found in nature as well. \\
\hline & & $\begin{array}{l}\text { Editor: In fact, tunnels are judged by how low their turbulence levels are rather than duplicating nature's } \\
\text { turbulence levels. }\end{array}$ \\
\hline $\begin{array}{l}\text { GT/CFD } \\
\text { Integration }\end{array}$ & 19 & $\begin{array}{l}\text { Rapid grid generation is a challenge in CFD: } \\
\text { - It will be a big focus in the next } 10 \text { to } 15 \text { years. }\end{array}$ \\
\hline $\begin{array}{l}\text { GT/CFD } \\
\text { Integration }\end{array}$ & 19 & $\begin{array}{l}\text { A major weakness of CFD is in turbulence modeling - you get a different answer depending on the flow } \\
\text { conditions. } \\
\text { - Yet, some test facilities cannot replicate the turbulence found in nature as well; or answer such } \\
\text { questions as when does the flow separate or when does it transition? } \\
\text { While these situations are improving, turbulence modeling is a pacing item, and is still not well } \\
\text { understood; but, again, this is very case dependent. }\end{array}$ \\
\hline \multirow[t]{2}{*}{ Efficiency } & \multirow[t]{2}{*}{1} & \multirow{2}{*}{$\begin{array}{l}\text { Changes of this magnitude during the flight-test program can have a profound impact on program cost and } \\
\text { schedule. } \\
\text { Editor: Changes for whatever reason during flight testing tend to be highly impactful on program schedule } \\
\text { and costs. }\end{array}$} \\
\hline & & \\
\hline Efficiency & 1 & $\ldots$ the amount of rework (cycles) normally performed, is also process driven \\
\hline \multirow[t]{2}{*}{ Efficiency } & \multirow[t]{2}{*}{8} & \multirow{2}{*}{$\begin{array}{l}\text { Defects discovered late during the development process not only increase cycle time but also can impact } \\
\text { manufacturing costs if significant tooling and production have already occurred. } \\
\text { Editor: As previously noted, easier to cut testing early and carry more risk, but can bite hard later. How is } \\
\text { the career process aligned with long-term decision outcomes? Is cost-cutting rewarded without regard to } \\
\text { system effect? }\end{array}$} \\
\hline & & \\
\hline \multirow[t]{2}{*}{ Efficiency } & \multirow[t]{2}{*}{16} & $\begin{array}{l}\text { This amount of wind tunnel testing drives cycle time for system development, which is one of the key } \\
\text { D\&SWS (Developing and Sustaining Warfighting Systems) effectiveness measures. }\end{array}$ \\
\hline & & Editor: Pay me now or pay me later for flight hardware reworks. \\
\hline Efficiency & 18 & Finding ways to create $\mathrm{W} / \mathrm{T}$ models faster and cheaper. \\
\hline \multirow[t]{2}{*}{ Efficiency } & \multirow[t]{2}{*}{19} & $\begin{array}{l}\text { Improvements are needed in wind tunnels: } \\
\text { - } \quad \text { Efficiency } \\
\text { - } \quad \text { Rapid prototyping } \\
\quad \text { New measurement techniques } \\
\circ \quad \text { Unsteady flow measurements } \\
\circ \quad \text { Skin-friction measurements } \\
\circ \quad \text { Non-intrusive: Pressure sensitive paint and particle image velocimetry. }\end{array}$ \\
\hline & & Editor: [Need more on new measurement techniques] \\
\hline Efficiency & 19 & $\begin{array}{l}\text { Running wind tunnel tests is the quickest way to fill in a database, especially if you want to capture control } \\
\text { (effector) power. }\end{array}$ \\
\hline \multirow[t]{2}{*}{ Sustainment } & \multirow[t]{2}{*}{3} & $\begin{array}{l}\text { The facilities that house fundamental research activities at NASA are typically old and require more } \\
\text { maintenance than funding permits. }\end{array}$ \\
\hline & & $\begin{array}{l}\text { Editor: NASA AETC (Aeronautics Evaluation and Test Capabilities) facilities have a } \$ 500 \mathrm{M} \text { maintenance } \\
\text { backlog. Facilities should be getting (per NASA policy) } 1.6 \% \text { of Current Replacement Value (CRV). LaRC } \\
\text { RD alone has approximately } \$ 2.5 \mathrm{~B} \text { CRV facilities. [So, what is the current expenditure? } \\
\text { Verification/reference for these numbers?] }\end{array}$ \\
\hline Sustainment & 3 & The lack of timely maintenance can lead to safety issues, particularly with large, high-powered equipment. \\
\hline \multirow[t]{2}{*}{ Sustainment } & \multirow[t]{2}{*}{$9 \mathrm{~b}$} & $\begin{array}{l}\text { Low-use facilities can be closed for long periods, but cost savings may be lower than expected and } \\
\text { capabilities will degrade quickly. }\end{array}$ \\
\hline & & Editor: Equipment and people. At some point, cost to bring back becomes prohibitive. \\
\hline \multirow[t]{2}{*}{ Sustainment } & \multirow[t]{2}{*}{$9 \mathrm{~b}$} & Mothballing a strategically important facility is preferred to closure, but mothballing still involves risk. \\
\hline & & Editor: And, to do it properly, money as well. \\
\hline Sustainment & 18 & $\begin{array}{l}\text {... existing tunnels are experiencing a steady decline in overall usage, forcing cutbacks that impact facility } \\
\text { up-keep and improvements. }\end{array}$ \\
\hline & & $\begin{array}{l}\text { Editor: NASA New Funding Model (implemented in FY17) is designed to improve this situation for NASA } \\
\text { AETC facilities. }\end{array}$ \\
\hline
\end{tabular}




\begin{tabular}{|c|c|c|}
\hline Sustainment & 18 & $\begin{array}{l}\ldots \text { for those tunnel facilities that are seen to have low utilization will be in danger of closure, further } \\
\text { degrading the nation's capability to maintain our global leadership in aerospace. }\end{array}$ \\
\hline Sustainment & 18 & $\begin{array}{l}\text {... maintenance and upgrades are an ever increasing and largely unfunded issue with the current tunnel } \\
\text { suite. }\end{array}$ \\
\hline Sustainment & 18 & The challenges of maintaining this infrastructure center on required costs and perceived value. \\
\hline \multirow[t]{2}{*}{ Sustainment } & \multirow[t]{2}{*}{19} & Over the years wind tunnel infrastructure has decayed and the workforce knowledge base has dwindled. \\
\hline & & $\begin{array}{l}\text { Editor: Preserving / increasing knowledgeable human capital in the US is waning. Initiatives are underway } \\
\text { to invest in workforce to meet future needs at AEDC for technical staff and for Air Force/NASA hypersonics } \\
\text { staffing in general, though funding is limited for both. }\end{array}$ \\
\hline \multirow[t]{2}{*}{ Investment } & \multirow[t]{2}{*}{5} & $\begin{array}{l}\text { A drastic increase in the knowledge of both the ambient and vehicle-generated disturbance fields and } \\
\text { modifiers thereof is necessary to enable transition to be predicted as an initial boundary-value problem... } \\
\text { Such knowledge of these fields for flight, both vehicle-generated and atmospheric, is essentially absent } \\
\text { and is also largely unknown for ground facilities. }\end{array}$ \\
\hline & & Editor: Key point and need; one of the specialty area staff needs noted previously. \\
\hline Investment & 5 & $\begin{array}{l}\text { The challenges that are faced by CFD (e.g., unsteady separation, boundary-layer transition) are such that } \\
\text { they cannot be resolved by the mere availability of faster machines. Research is needed for the } \\
\text { development of more accurate numerical schemes, advanced solver technology, grid adaptation, error } \\
\text { estimation, physics modeling, and schemes for efficiently exploiting the capabilities of future massively } \\
\text { parallel machines. }\end{array}$ \\
\hline Investment & 5 & $\begin{array}{l}\text { In order to assess the role of modeling errors and develop better physical models, a need exists for detailed } \\
\text { unit experiments that involve simple configurations for which grid generation and the associated } \\
\text { discretization errors are not the issue. }\end{array}$ \\
\hline Investment & 5 & $\begin{array}{l}\text { Most needed are additional unit experiments that provide detailed data for assessing modeling errors in } \\
\text { the available CFD technology and the development of new models for complex turbulent flows. }\end{array}$ \\
\hline \multirow[t]{2}{*}{ Investment } & \multirow[t]{2}{*}{5} & $\begin{array}{l}\text { Research in grid generation is generally under-valued, but it is important to note that grid generation is not } \\
\text { a solved problem. }\end{array}$ \\
\hline & & $\begin{array}{l}\text { Editor: Grid generation appears to be the bigger (efficiency) issue for CFD than the actual CFD } \\
\text { computation. }\end{array}$ \\
\hline Investment & 6 & $\begin{array}{l}\text { Knowledge Extraction and Visualization. An integral part of effectively using the advanced CFD technology } \\
\text { envisioned in } 2030 \text { is the way in which the very large amount of CFD-generated data can be harvested } \\
\text { and utilized to improve the overall aerodynamic design and analysis process. }\end{array}$ \\
\hline \multirow[t]{2}{*}{ Investment } & \multirow[t]{2}{*}{11} & $\begin{array}{l}\text { Acoustic and turbulence levels in existing large-scale facilities are too high to achieve the aeronautics } \\
\text { goals in the } 2010 \text { National Aeronautics R\&D Plan. }\end{array}$ \\
\hline & & $\begin{array}{l}\text { Editor: This seems contrary to the statement above that states we are not duplicating free-air turbulence } \\
\text { levels. Are we too quiet or too noisy??? }\end{array}$ \\
\hline Investment & 11 & $\begin{array}{l}\text { Current combustor component test facilities offer lower flow rate capability than required and thus limit } \\
\text { component testing. }\end{array}$ \\
\hline Investment & 11 & $\begin{array}{l}\ldots \text { limitation of current facilities contributes to the expense of highly conservative material designs for } \\
\text { hypersonic vehicle airframe thermal protection systems and propulsion system inlet leading edges. }\end{array}$ \\
\hline Investment & 11 & $\begin{array}{l}\text { No facility is now available to conduct research by testing turbine engines at altitude for icing conditions } \\
\text { that include ice particles. }\end{array}$ \\
\hline Investment & 11 & $\begin{array}{l}\text { The current infrastructure fails to meet required capabilities because of three limitations. The first is the } \\
\text { inability to test full-scale propulsion systems because of limited test cell size and limited mass flow } \\
\text { capability. The second limitation is the inability to test scramjets at Mach numbers greater than } 5 \text { in clean } \\
\text { air and greater than } 7 \text { in vitiated air because current high Mach number facilities are limited in mass flow, } \\
\text { flow quality, and run time. The third limitation is the inability to vary the wind speed during a test (time- } \\
\text { variant Mach number). }\end{array}$ \\
\hline Investment & 11 & The gap in materials testing is the inability to duplicate the flight envelope between current facilities. \\
\hline \multirow[t]{2}{*}{ Investment } & \multirow[t]{2}{*}{11} & $\begin{array}{l}\text { There is a gap in the capability to flight test on-board avionics systems as part of the Next Generation Air } \\
\text { Transportation System (NextGen) and the increased safety-of-flight goals. }\end{array}$ \\
\hline & & Editor: AEDC would say they are testing hardware in the loop for engines. \\
\hline \multirow[t]{2}{*}{ Investment } & \multirow[t]{2}{*}{14} & $\begin{array}{l}\text {... data storage media will not support future } \mathrm{HS} / \mathrm{H} \text { system requirements, and data distribution } \\
\text { requirements for future hypersonic missions will exceed the capability of current distribution networks. }\end{array}$ \\
\hline & & $\begin{array}{l}\text { Editor: This is a true statement for every flight regime. Wanting and getting more data from a single test } \\
\text { entry. High speed and dynamic behavior physics capture requires high speed data collection - a lot of } \\
\text { data quickly. }\end{array}$ \\
\hline Investment & 14 & ... some shortfalls exist in our range infrastructure to adequately validate their applicable technologies. \\
\hline Investment & 14 & A flight-test gap exists in the capability to air-launch the heavier hypersonic missile systems. \\
\hline Investment & 14 & $\begin{array}{l}\text { Although short run times may be useful for evaluating performance at discrete design points, seconds, } \\
\text { minutes, or tens of minutes of run time will be required for operability and durability testing. }\end{array}$ \\
\hline \multirow[t]{2}{*}{ Investment } & \multirow[t]{2}{*}{14} & $\begin{array}{l}\text { As with the case of aerodynamic testing, test time is an issue and a gap for any testing above Mach 10, } \\
\text { which is needed for the Mach } 8 \text { to } 12 \text { Hypersonic Interceptor/Attack Missile. }\end{array}$ \\
\hline & & $\begin{array}{l}\text { Editor: Not necessarily true; for most flow phenomena of concern to aerodynamics, LENS provides } \\
\text { adequate test time between Mach } 8 \text { and } 12 \text { and beyond. }\end{array}$ \\
\hline Investment & 14 & $\begin{array}{l}\text {... deficiencies in areas such as micro-instrumentation development and the difficulty in calibrating various } \\
\text { instrumentation components to the vehicle's operating speed. }\end{array}$ \\
\hline
\end{tabular}




\begin{tabular}{|c|c|c|}
\hline Investment & 14 & $\begin{array}{l}\text { Development of a programmed accelerating and decelerating hypersonic propulsion system is considered } \\
\text { to be a challenge for both the engine designer and the test facility designer. }\end{array}$ \\
\hline Investment & 14 & $\begin{array}{l}\text { Gaps between current capabilities and required capabilities were the basis for determining a HS/H T\&E } \\
\text { capability requirement roadmap. }\end{array}$ \\
\hline Investment & 14 & $\begin{array}{l}\text { Hypersonic wind tunnel productivity is an issue, especially above Mach } 10 . \\
\text { Editor: A major part of the challenge is having the qualified people/staff. }\end{array}$ \\
\hline Investment & 14 & ... improvements in inlet airframe integration and nozzle after-body test capabilities are needed. \\
\hline Investment & 14 & $\begin{array}{l}\text { Reasonably good hypersonic perfect gas aerodynamic wind tunnels exist today, but none simulate the } \\
\text { real-gas and aerothermal effects encountered in flight at Mach numbers above } 8 \text {. } \\
\text { Editor: See note above regarding LENS. }\end{array}$ \\
\hline Investment & 14 & $\begin{array}{l}\text { Several drawbacks exist in today's sensor systems. First, they are generally intrusive. Second, they are } \\
\text { less reliable than the hardware that is being monitored. Third, most need manual calibration. Fourth, they } \\
\text { are unable to detect when the output is degraded or has failed. Finally, they cannot detect off-nominal } \\
\text { reading caused by the effects of failures in other parts of the system. } \\
\text { Fditor- Kev area of need - sensors and measurements }\end{array}$ \\
\hline Investment & 14 & $\begin{array}{l}\text { The effects and limitations of combustion-vitiated testing, development of clean air test facilities below } \\
\text { Mach } 8 \text {, definition of needed facility runs times, and definition/development of test capabilities above Mach } \\
8 \text { are all test facility technology gaps that must be addressed. }\end{array}$ \\
\hline Investment & 14 & $\begin{array}{l}\text { The flight condition simulation capabilities required for the transformational } \mathrm{HS} / \mathrm{H} \text { systems envisioned far } \\
\text { exceed current ground-test capabilities. }\end{array}$ \\
\hline Investment & 14 & $\begin{array}{l}\ldots \text { the higher the system performance Mach number, the larger the gap in the ability to test the system } \\
\text { using today's facilities. }\end{array}$ \\
\hline \multirow[t]{2}{*}{ Investment } & \multirow[t]{2}{*}{14} & $\begin{array}{l}\text { The large engine test facilities are limited to Mach 3.2, yet turbine engine R\&D programs predict future } \\
\text { engine performance to Mach } 4 \text { and above. }\end{array}$ \\
\hline & & $\begin{array}{l}\text { Editor: Much of the existing capabilities are of the post-WWII vintage plus facility improvements. Future } \\
\text { needs push engine performance even more. Currently, the NASA Glenn PSL-4 facility is rated to Mach } \\
4.0 .^{26} \text { Efforts are underway to configure and validate facilities with higher capability. Will their completion } \\
\text { match a timeframe that industry would find productive? }\end{array}$ \\
\hline Investment & 14 & The need for highly productive cold-flow facilities will continue to exist as before. \\
\hline \multirow[t]{2}{*}{ Investment } & \multirow[t]{2}{*}{14} & $\begin{array}{l}\text { The primary propulsion test capability that exists above Mach } 8 \text { currently is relatively small impulse (shock) } \\
\text { tunnels where the test time is of the order of milliseconds and the test medium is usually not clean air. }\end{array}$ \\
\hline & & $\begin{array}{l}\text { Editor: Current short duration facilities can test full scale } 1 \mathrm{X} \text { complete vehicle configurations, } 10 \mathrm{X} \text { scale } \\
\text { uninstalled engine flowpaths can also be evaluated. Test times are on the order of } 100 \mathrm{~ms} \text { at Mach } 6 \text { flight } \\
\text { conditions. }\end{array}$ \\
\hline \multirow[t]{2}{*}{ Investment } & \multirow[t]{2}{*}{14} & $\ldots$ there is a gap in providing the correct flow chemistry. \\
\hline & & Editor: See note above regarding LENS. \\
\hline Investment & 14 & There is a gap in the ability to cost-effectively recover expendable hypersonic vehicles for data analysis. \\
\hline Investment & 14 & $\begin{array}{l}\text {... there is a need for real-gas flight simulation test capability, and/or analytical procedures are needed to } \\
\text { correct data taken from perfect gas and nonreal-gas wind tunnels to predict flight results. }\end{array}$ \\
\hline Investment & 14 & $\begin{array}{l}\text { This lack of needed data is largely the result of shortcomings in existing test facilities and partly a result of } \\
\text { the lack of a comprehensive approach to capturing needed validation data. }\end{array}$ \\
\hline Investment & 14 & This will require a test facility with a variable Mach number test capability. \\
\hline \multirow[t]{2}{*}{ Investment } & \multirow[t]{2}{*}{18} & High Rn low-turbulence flow for high-speed platforms." \\
\hline & & Editor: $\mathrm{Rn}$ is Reynolds number. Low turbulence or accurate turbulence? \\
\hline Investment & 18 & $\begin{array}{l}\text { It goes on to recommend future capabilities: } \\
\text { - Multi-mission capability. Any new test facility must be capable of a broad range of test types and } \\
\text { speed ranges. Speeds from } \mathrm{M}=0 \text { to } \mathrm{M}=5.0 \text {, altitude simulations up to } 80,000 \mathrm{ft} \text { (stratospheric } \\
\text { testing), Reynolds numbers up to } 5 \text { million/ft should be capability goals. } \\
\text { - Moderate Test sections size. Approximate } 60 \text { to } 100 \text { sq. ft. test section size is a reasonable } \\
\text { compromise between high-cost large-volume test section sizes for large models and efficient, low- } \\
\text { operational-cost smaller facilities. This nominal test section size facilitates models of reasonable } \\
\text { size to obtain reliable data and without flow issues such as blockage, flow breakdown, and shock } \\
\text { reflections. } \\
\text { - Advanced data mining capability. Real-time quantitative and visualization data of on- and off-body } \\
\text { flow fields will be required to integrate and validate computational simulations. } \\
\text { Excellent test section optical access for application of developing on- and off-body flow visualization } \\
\text { and measurements. Future data mining requirements (above) will drive significant optical access } \\
\text { requirements. } \\
\text { Ease of access and installation. With the anticipation that future windows will require rapid access, } \\
\text { new capabilities must have extremely rapid access. The ability to install and test a model within a } \\
\text { single operational shift is essential. } \\
\text { Highly automated testing. Efficient and highly productive operations will drive crew sizes down in } \\
\text { favor of automation. Tunnel and model automation capability are a must for any future capability. } \\
\text { Highly connected facility. Full remote access, including data streaming, audio and video feeds (to } \\
\text { facilitate virtual presence), will enable test teams to be spread across the nation without the } \\
\text { requirement to physically attend testing. Fully integrated computational access to existing design } \\
\text { simulation or test databases is essential. }\end{array}$ \\
\hline
\end{tabular}




\begin{tabular}{|c|c|c|}
\hline & & $\begin{array}{l}\text { - Ability to create model configurations on-site. Rapid model creation capability (as discussed in } \\
\text { previous sections) will become essential to a rapid test mindset. } \\
\text { Energy efficiency. Any new facility must be extremely energy efficient. Evaluation of non-traditional } \\
\text { designs such as oval circuits, multi-cycle test environments, extremely low-friction circuit design, } \\
\text { and variable test section sizes should be important considerations. } \\
\text { - Expert staff. Test success is more often influenced by the expertise and behavior of the staff than } \\
\text { by equipment or underlying infrastructure. To enable rapid, efficient, and successful testing, a well- } \\
\text { rounded staff of experts (in both facility operation and aircraft development) is needed. The ability to } \\
\text { perform testing without extensive customer presence absolutely revolves around a facility having } \\
\text { expertise and efficient processes." }\end{array}$ \\
\hline & & Editor: Reynolds number of $5 \mathrm{M}$ seems low if we are trying to duplicate speed \& altitude. \\
\hline \multirow[t]{2}{*}{ Investment } & \multirow[t]{2}{*}{18} & $\begin{array}{l}\text { Based on our customers' needs . . . Lockheed Martin finds several areas of emerging technology and } \\
\text { development challenge that will require improved test and evaluation assets. These are: } \\
\text { - } \quad \text { High-speed testing for transonic to hypersonic vehicles } \\
\text { - } \quad \text { Low Reynolds number (Rn) micro UAV flight (ultra low turbulence) simulation } \\
\text { - Unsteady aerodynamic testing for flapping wing } \\
\text { - } \quad \text { Urban flow, large-turbulence testing for micro vehicles and hybrid airships } \\
\text { - Stratospheric test capability ranging in Mach numbers from } 0.5 \text { to2.5, Rn/ft up to } 5 \text { million, dynamic } \\
\text { pressures up to } 1500 \text { psf and simulating altitudes up to } 80,000 \mathrm{ft} \text { are required } \\
\text { Low Rn, ultra-low-turbulence flow for ISR platform testing } \\
\text { High Rn low-turbulence flow for high-speed platforms. }\end{array}$ \\
\hline & & Editor: Low turbulence or accurate turbulence? \\
\hline Investment & 18 & $\begin{array}{l}\text { What capabilities will be needed and how will they need to work and be managed? Anchor point limited } \\
\text { wind tunnel test. }\end{array}$ \\
\hline Investment & 18 & $\begin{array}{l}\text { What capabilities will be needed and how will they need to work and be managed? Data mining and Real } \\
\text { time quantitative and visualization of on and off body flow fields. }\end{array}$ \\
\hline Investment & 18 & $\begin{array}{l}\text { What capabilities will be needed and how will they need to work and be managed? Integrated process } \\
\text { looping through CFD modeling, rapid prototyping and automated testing. }\end{array}$ \\
\hline Investment & 18 & $\begin{array}{l}\text { What capabilities will be needed and how will they need to work and be managed? W/T would need large } \\
\text { speed ranges with flow visualization at any speed, adaptable to various types of testing and be highly } \\
\text { automated to reduce the need for model changes. }\end{array}$ \\
\hline \multirow[t]{2}{*}{ Investment } & \multirow[t]{2}{*}{19} & $\begin{array}{l}\text { A large-scale (16-ft square test section) (AEDC/16S) supersonic (hypersonic?) wind tunnel testing } \\
\text { capability is needed for the development of expanded missile defense vehicles. } \\
\text { - If the wind tunnel is not there, we must build extra margin into the vehicle at increased cost and risk. } \\
\text { - If additional risk in the vehicle is not acceptable, we may have to determine if we can no longer } \\
\text { develop that type of vehicle. }\end{array}$ \\
\hline & & Editor: AEDC is resurrecting $16 \mathrm{~S}$; see editor note above. \\
\hline Investment & 19 & $\begin{array}{l}\text { Improvements are needed in wind tunnels: } \\
\text { - } \quad \text { Efficiency } \\
\text { - } \quad \text { Rapid prototyping } \\
\quad \text { measurement techniques } \\
\circ \quad \text { Unsteady flow measurements } \\
\circ \quad \text { Skin-friction measurements } \\
\circ \quad \text { Non-intrusive: Pressure sensitive paint and particle image velocimetry }\end{array}$ \\
\hline \multirow[t]{2}{*}{ Investment } & \multirow[t]{2}{*}{19} & $\begin{array}{l}\text { The challenge of aerodynamic testing is powered models. Techniques are needed to help us handle these } \\
\text { situations. }\end{array}$ \\
\hline & & Editor: Powered testing at full scale Reynolds number is even more challenging for sub-scale models \\
\hline Staffing & $9 \mathrm{~b}$ & $\begin{array}{l}\text { An alternative is to provide strategic financial support for periodic use of the capabilities to exercise staff } \\
\text { and equipment to maintain knowledge, skills, and equipment. }\end{array}$ \\
\hline Staffing & 18 & $\begin{array}{l}\text { AIAA Ground Test Technical Committee (GTTC) made the following recommendations: } \\
\text { 1) "Development of a knowledgeable test workforce is critical for the national infrastructure." } \\
\text { 2) "Improved test technology is crucial to enabling future system development." } \\
\text { 3) "Maintenance and improvement of key test assets is a vital component of enabling future test } \\
\text { capabilities." } \\
\text { 4) "Divestment of redundant and nonessential test infrastructure is required to focus limited resources on } \\
\text { critical capabilities and new infrastructure requirements." } \\
\text { 5) "New high-speed test infrastructure is required to meet anticipated requirements for future systems." }\end{array}$ \\
\hline \multirow[t]{2}{*}{ Staffing } & \multirow[t]{2}{*}{19} & Over the years wind tunnel infrastructure has decayed and the workforce knowledge base has dwindled. \\
\hline & & $\begin{array}{l}\text { Editor: Noted previously; wind tunnels have been in a declining phase since at least the early 1990's - } \\
\text { limited budgets have limited maintenance and investments in infrastructure and staff. Investments have } \\
\text { stabilized in recent years to at least slow the declines and, in some cases (like the Air Force hypersonics } \\
\text { T\&E capabilities investment of } \$ 350 \mathrm{M} \text { over } 5 \text { years starting in 2017) turning up. }\end{array}$ \\
\hline Staffing & 19 & We are running the risk of losing people with experimental expertise because we are doing less testing. \\
\hline Strategic & 1 & $\begin{array}{l}\text {... military systems which provide the most technically challenging environment for large-scale computing. } \\
\text { Military systems fly over larger speed ranges and operating envelopes, have more intense integration }\end{array}$ \\
\hline
\end{tabular}




\begin{tabular}{|c|c|c|}
\hline & & $\begin{array}{l}\text { issues such as low observable, weapons integration, buried inlet/engine configurations, etc. and have a } \\
\text { much more challenging multiorganizational environment in which to implement CSE. }\end{array}$ \\
\hline Strategic & 3 & $\begin{array}{l}\text { NASA laboratories as marginally adequate, with some clearly being totally inadequate and others being } \\
\text { very adequate. }\end{array}$ \\
\hline Strategic & 6 & Lack of explicit collaboration among turbulence researchers. \\
\hline \multirow[t]{2}{*}{ Strategic } & \multirow[t]{2}{*}{$9 \mathrm{~b}$} & $\begin{array}{l}\text { An alternative is to provide strategic financial support for periodic use of the capabilities to exercise staff } \\
\text { and equipment to maintain knowledge, skills, and equipment. }\end{array}$ \\
\hline & & Editor: Must have test cycles to train and hone skills. \\
\hline \multirow[t]{2}{*}{ Strategic } & \multirow[t]{2}{*}{$9 \mathrm{~b}$} & $\begin{array}{l}\text { Low-use facilities can be closed for long periods, but cost savings may be lower than expected and } \\
\text { capabilities will degrade quickly. }\end{array}$ \\
\hline & & $\begin{array}{l}\text { Editor: Not a great solution, but does push decisions downstream (where it costs even more). Typically, } \\
\text { low near-term savings since low-use facilities have already had maintenance reduced. And staffing issues } \\
\text { worsen. }\end{array}$ \\
\hline \multirow[t]{2}{*}{ Strategic } & \multirow[t]{2}{*}{$9 \mathrm{~b}$} & Mothballing a strategically important facility is preferred to closure, but mothballing still involves risk. \\
\hline & & Editor: Costly to mothball properly and huge staffing issues. \\
\hline Strategic & 10 & $\begin{array}{l}\text { A number of fundamental challenges are barriers to technical progress, as well as opportunities for } \\
\text { advancement through sustained aeronautics R\&D. }\end{array}$ \\
\hline \multirow[t]{2}{*}{ Strategic } & \multirow[t]{2}{*}{11} & Comprehensive interagency management policies for aeronautics infrastructure do not yet exist. \\
\hline & & Editor: Local priorities and budgets; stovepipes. \\
\hline Strategic & 11 & $\begin{array}{l}\text { Shortfalls associated with the state of the art discussed above will have to be overcome to continually } \\
\text { improve safety (challenges) in the decades ahead. }\end{array}$ \\
\hline \multirow[t]{2}{*}{ Strategic } & \multirow[t]{2}{*}{11} & $\begin{array}{l}\text { The following tables can be used to identify the national aeronautics R\&D goals and objectives that are } \\
\text { impacted by the shortfalls identified in this RDT\&E infrastructure plan. The first table lists each of the } \\
\text { shortfalls in the left column and then lists codes for the specific goals and objectives that are impacted by } \\
\text { the shortfalls. . . The second table displays the entire list of the national aeronautics R\&D goals and } \\
\text { objectives, numbering each goal and objective, and associates them with the codes used in the first table. }\end{array}$ \\
\hline & & $\begin{array}{l}\text { Editor: These tables are large/comprehensive/extensive and too large to be included in this paper, but are } \\
\text { referenced for the interested reader. }\end{array}$ \\
\hline Strategic & 14 & $\begin{array}{l}\ldots \text { definition/development of test capabilities above Mach } 8 \text { are all test facility technology gaps that must } \\
\text { be addressed. }\end{array}$ \\
\hline Strategic & 14 & $\begin{array}{l}\text { The challenge for developing an integrated roadmap for } \mathrm{HS} / \mathrm{H} \text { engineering development and test and } \\
\text { evaluation (T\&E) capability requirements is to identify the capability requirements for each discipline. }\end{array}$ \\
\hline Strategic & 14 & $\begin{array}{l}\text { This lack of needed data is largely the result of shortcomings in existing test facilities and partly a result of } \\
\text { the lack of a comprehensive approach to capturing needed validation data. }\end{array}$ \\
\hline Strategic & 14 & $\begin{array}{l}\text { Ramjet and Scramjet Engine Acceleration Testing - Most of the off-ramp vehicles will require a ramjet or } \\
\text { scramjet engine to change thrust output as the vehicle accelerates or decelerates. This will require a test } \\
\text { facility with a variable Mach number test capability. }\end{array}$ \\
\hline Strategic & 18 & $\begin{array}{l}\text { AIAA Ground Test Technical Committee (GTTC) made the following recommendations: } \\
\text { 1) "Development of a knowledgeable test workforce is critical for the national infrastructure." } \\
\text { 2) "Improved test technology is crucial to enabling future system development." } \\
\text { 3) "Maintenance and improvement of key test assets is a vital component of enabling future test } \\
\text { capabilities." } \\
\text { 4) "Divestment of redundant and nonessential test infrastructure is required to focus limited resources on } \\
\text { critical capabilities and new infrastructure requirements." } \\
\text { 5) "New high-speed test infrastructure is required to meet anticipated requirements for future systems." }\end{array}$ \\
\hline Strategic & 18 & $\begin{array}{l}\text { In } 2008 \text { the GTTC made recommendations for the future of W/T testing but so far no champion has stepped } \\
\text { up to take on the challenges, except maybe for the efforts being done by this working group. }\end{array}$ \\
\hline Strategic & 18 & $\begin{array}{l}\text { The aerospace industry (both government and private sector) must adapt to a strategy of maintaining and } \\
\text { operating key and critical wind tunnels as essential assets which insures the nation's leadership in the } \\
\text { aerospace field. }\end{array}$ \\
\hline Strategic & 19 & We are losing our edge in test capabilities. \\
\hline Programmatic & 1 & $\begin{array}{l}\text { The incremental increase in program costs is proportional to }(1 / q)-1 \text {, indicating the potential to easily } \\
\text { double development costs through late defects and rework. }\end{array}$ \\
\hline Programmatic & 2 & $\begin{array}{l}\text { NASA's research goals in aeronautics are not currently closely aligned with the aerospace industry's } \\
\text { needs. }\end{array}$ \\
\hline Programmatic & 2 & $\begin{array}{l}\text { NASA aeronautics' current organization, which relies on program management from NASA Headquarters, } \\
\text { drives behaviors that inhibit collaboration, stifle innovation and risk-taking, and limit the organization's } \\
\text { ability to effectively prioritize its programs to a critical few. }\end{array}$ \\
\hline Programmatic & 3 & $\begin{array}{l}\text {... if funding continues to decline, NASA may not be able to claim aeronautics technology leadership from } \\
\text { an international and in some areas even a national perspective. }\end{array}$ \\
\hline Programmatic & 3 & $\begin{array}{l}\text { Based on the experience and expertise of its members, the committee believes that the equipment and } \\
\text { facilities at NASA's basic research laboratories are inferior. }\end{array}$ \\
\hline \multirow[t]{2}{*}{ Programmatic } & \multirow[t]{2}{*}{3} & $\begin{array}{l}\text { Over the past } 5 \text { years or more, the funding of fundamental research at NASA, including the funding of } \\
\text { facilities and equipment, has declined dramatically. }\end{array}$ \\
\hline & & Editor: Shown earlier; this has stabilized in recent years but underfunding persists. \\
\hline Programmatic & $9 \mathrm{~b}$ & $\begin{array}{l}\text { An alternative is to provide strategic financial support for periodic use of the capabilities to exercise staff } \\
\text { and equipment to maintain knowledge, skills, and equipment. }\end{array}$ \\
\hline
\end{tabular}




\begin{tabular}{|c|c|c|}
\hline & & ditor: Will have to be provided by the government or a government/industry cooperative arrangement. \\
\hline Programmatic & $9 \mathrm{~b}$ & $\begin{array}{l}\text {-ow-use facilities can be closed for long periods, but cost savings may be lower than expected and } \\
\text { sapabilities will degrade quickly. }\end{array}$ \\
\hline Programmatic & $9 b$ & othballing a strategically important facility is preferred to closure, but mothballing still involves risk. \\
\hline Programmatic & 11 & $\begin{array}{l}\text { ere is a shortfall in the capability to flight test hypersonic vehicles overland and limitations on the ability } \\
\text { test over the ocean. }\end{array}$ \\
\hline Programmatic & 13 & $\begin{array}{l}\text { Despite numerous attempts at acquisition reform, the number of acquisition programs behind schedule } \\
\text { and over costs continues to escalate. }\end{array}$ \\
\hline Programmatic & 14 & lies in advanced ground support systems for hypersonic vehicles. \\
\hline Programmatic & 14 & $\begin{array}{l}\ldots \text { definition/development of test capabilities above Mach } 8 \text { are all test facility technology gaps that must } \\
\text { be addressed. }\end{array}$ \\
\hline Programmatic & 14 & $\begin{array}{l}\text { Metric tracking of platforms flying at hypersonic speeds are limited by present tracking system slew rates } \\
\text { and response times, which are too slow to maintain track. }\end{array}$ \\
\hline Programmatic & 16 & $\begin{array}{l}\text { Today it takes approximately } 2.5 \text { million data points in a wind tunnel test program to develop the stability } \\
\text { and control (S\&C) and performance laws database for a SUT [systems under test]. }\end{array}$ \\
\hline & & e time and data quality comparison of collecting this data in a WT vs CFD \\
\hline Progra & 19 & e don't know how to measure the infrastructure cost of CFD (high-end computers, personnel, etc.). \\
\hline Programmatic & 18 & This is analogous to the national highway system which does not generate income directly but without \\
\hline
\end{tabular}

F. Recommendations

\begin{tabular}{|c|c|c|}
\hline Group & $\begin{array}{l}\text { Doc } \\
\text { Ref \# }\end{array}$ & Excerpted Material and Editorial Comments \\
\hline Approach & 10 & $\begin{array}{l}\text { Demonstrate increased cruise lift-to-drag and innovative airframe structural concepts for highly efficient } \\
\text { high-altitude flight and for mobility aircraft. The ability to cruise efficiently at a range of altitudes, enabled } \\
\text { by a substantial increase in cruise lift-to-drag ratios over today's high-altitude reconnaissance aircraft, is a } \\
\text { critical goal and key element in support of national security, providing sustained presence, long range, and } \\
\text { advanced sensing capabilities. }\end{array}$ \\
\hline Approach & 10 & Demonstrate reduced gas turbine specific fuel consumption. \\
\hline Approach & 10 & $\begin{array}{l}\text { Develop improved lift, range, and mission capability for rotorcraft. } \\
\text { - } \quad \text { Advanced rotors and rotor hubs, possibly with active blade control, that produce higher lift with } \\
\text { reduced loads, vibration, noise, and downwash over a range of flight conditions. } \\
\text { - High-speed, high-torque drive trains that are quieter, more robust, and require less maintenance. } \\
\text { - } \quad \text { Rotors, prop-rotors, transmissions, propulsion systems, and vehicle control systems that allow large } \\
\text { variations in rotor speed and a wider range of operation. } \\
\text { - Advanced digital flight control systems, vehicle management systems and system architectures that } \\
\text { enable enhanced aircraft safety and survivability, improve handling qualities, reduce platform } \\
\text { weight, reduce life cycle cost, and support a diverse range of vehicles and missions. }\end{array}$ \\
\hline Approach & 11 & A large static rig facility is needed for testing full-scale prototype rotorcraft systems. \\
\hline Approach & 11 & $\begin{array}{l}\text {... the development of } \mathrm{N}+1, \mathrm{~N}+2 \text {, and } \mathrm{N}+3 \text { aircraft requires the capability to replicate conditions allowing } \\
\text { full annular combustor testing. }\end{array}$ \\
\hline Approach & 11 & $\begin{array}{l}\text { Understanding the physics of ice particle threats is necessary to develop monitoring strategies for safe } \\
\text { turbine engine operations. }\end{array}$ \\
\hline \multirow[t]{2}{*}{ Approach } & \multirow[t]{2}{*}{16} & $\begin{array}{l}\text { An integrated use of CFD and MDOE, a Basic study for vortex-dominated or massively separated flows, } \\
\text { and development of the database for high angle of attack phenomena. }\end{array}$ \\
\hline & & Editor: What about the integration of WT test too? Implied in MDOE? \\
\hline \multirow[t]{2}{*}{ Approach } & \multirow[t]{2}{*}{16} & Basic data analysis and reporting should be considered an inherent cost of testing by the customer. \\
\hline & & $\begin{array}{l}\text { Editor: So, not just a data mill. This supports data quality, documents issues and best practices, forces } \\
\text { staff to look at results (versus plan), and supports the future. }\end{array}$ \\
\hline \multirow[t]{2}{*}{ Approach } & \multirow[t]{2}{*}{16} & Provide more consistent and effective technical reviews. \\
\hline & & $\begin{array}{l}\text { Editor: This forces test performance assessment from user and service provider perspectives; important } \\
\text { for relationship building, documenting what worked and what had issues (important for future testing), and } \\
\text { used for input for capability and process improvements. }\end{array}$ \\
\hline Approach & 19 & $\begin{array}{l}\text { The challenge of aerodynamic testing is powered models. Techniques are needed to help us handle these } \\
\text { situations. }\end{array}$ \\
\hline \multirow[t]{2}{*}{ Approach } & \multirow[t]{2}{*}{19} & We must analyze the wind tunnel in its environment with all interferences in order to understand it. \\
\hline & & Editor: This is also critical in CFD/GT integration. \\
\hline Approach & 19 & $\begin{array}{l}\text { We must develop test and measurement techniques that go beyond what pressure-sensitive paint has } \\
\text { been promising for the past } 10 \text { years. }\end{array}$ \\
\hline \multirow[t]{2}{*}{ GT/CFD } & \multirow[t]{2}{*}{1} & $\begin{array}{l}\text { impact on the effectiveness of the development process. } \\
\text { impact on the be created for innovative ways to bring CSE and testing together to have the maximum }\end{array}$ \\
\hline & & $\begin{array}{l}\text { Editor: A major question is who will have the authority and the resources to lead an effort with maximum } \\
\text { results as its goal? Does the US have the will to do this? }\end{array}$ \\
\hline
\end{tabular}




\begin{tabular}{|c|c|c|}
\hline GT/CFD & 1 & $\begin{array}{l}\text { To successfully integrate CSE and testing will require advances not only in high-performance computing } \\
\text { but in intellectual capital and process management as well. Key recommendations for advancing the use } \\
\text { of CSE are as follows: } \\
\text { - Most importantly, the government has to adopt a monopsony for the application of CSE to the } \\
\text { development process for military flight systems. } \\
\text { A common architecture for the application of multidisciplinary computational tools in a high- } \\
\text { performance computing environment needs to be adopted by the industry. This architecture should } \\
\text { not preclude use of proprietary physical models from industry, but should enable CSE and testing to } \\
\text { be optimized for use across any aeronautical development process. } \\
\text { In spite of computer hardware systems advances, there is still much work to be done in building } \\
\text { software tools to best use advanced computer systems, notably, better physics modeling, scalability } \\
\text { of solvers to tens of thousands of processors, and better multidisciplinary modeling to enable } \\
\text { dynamic simulation of complete maneuvering aircraft. } \\
\text { CSE alone will not provide maximum impact to cycle time reduction but must be integrated with other tools } \\
\text { such as design of experiments, streamlined test methodologies, advanced diagnostic tools, networking, } \\
\text { and knowledge management. In addition, a concept of operations and the necessary computing capacity } \\
\text { need to be developed to support the aeronautical systems engineering process. }\end{array}$ \\
\hline GT/CFD & 1 & $\begin{array}{l}\text { Clearly, a strategy for providing sufficient capacity as well as a CONOPS to support design and } \\
\text { development of systems will be required to enable any potential success for large-scale application of CSE } \\
\text { to the development process. }\end{array}$ \\
\hline GT/CFD & 1 & $\begin{array}{l}\text { The proper national debate that needs to be held is not CSE versus test facilities. The aeronautics } \\
\text { community would be better served putting their energy into creating a vision for how CSE can be integrated } \\
\text { with physical testing processes to increase the effectiveness of both during the development of systems. } \\
\text { C. The elements that need to be advanced to re-engineer the aeronautical development process include } \\
\text { CSE as well as test facilities. In addition, a vision needs to be created for innovative ways to bring CSE } \\
\text { and testing together to have the maximum impact on the effectiveness of the development process. }\end{array}$ \\
\hline \multirow[t]{2}{*}{ GT/CFD } & \multirow[t]{2}{*}{5} & $\begin{array}{l}\text {... the national discussion at this stage should not be about shutting down test facilities in the near future } \\
\text { because of HPC but about how to use HPC to increase the effectiveness of the aeronautical development } \\
\text { process by reducing the design/acquisition cycle time. }\end{array}$ \\
\hline & & Editor: Major point - investments going forward must include EFD and CFD to meet requirements. \\
\hline \multirow[t]{2}{*}{ GT/CFD } & \multirow[t]{2}{*}{5} & $\begin{array}{l}\text { The question to ask is "What new computational tools and hardware should be developed alongside new } \\
\text { testing facilities and techniques so that a complementary set of tools to best advance product development } \\
\text { efforts and reduce risk in the future can be realized?" }\end{array}$ \\
\hline & & Editor: See previous comment. \\
\hline GT/CFD & 5 & $\begin{array}{l}\text { A national strategy that focuses investment in both the computational and experimental arenas to optimize } \\
\text { both capability and availability is essential. The current debate should be on how to integrate CFD and } \\
\text { wind-tunnel testing technologies comprehensively to bring more value to the product-development cycle. }\end{array}$ \\
\hline \multirow[t]{2}{*}{ GT/CFD } & \multirow[t]{2}{*}{6} & $\begin{array}{l}\text { NASA should lead efforts to develop and execute integrated experimental testing and computational } \\
\text { validation campaigns. }\end{array}$ \\
\hline & & $\begin{array}{l}\text { Editor: Research into integration is happening - see the LaRC UPWT initiative - but funding is limited. The } \\
\text { effort needs a champion. }\end{array}$ \\
\hline \multirow[t]{2}{*}{ GT/CFD } & \multirow[t]{2}{*}{8} & $\begin{array}{l}\text { A suggested approach to combining modeling and testing to reduce systemic late defects is illustrated in } \\
\text { Figure .... Using Bayesian statistics, the probability of finding a structural flaw in flight is an accumulation } \\
\text { of the probabilities of a flaw being overlooked either in design, analysis, ground testing, or assembly of the } \\
\text { prototype flight article. Since the flight test occurs several years after the design and ground testing phases, } \\
\text { a root cause analysis of structural failures traceable back to the design, analysis, or wind tunnel testing } \\
\text { phase is essentially never done. Consequently, these systemic issues show up in program after program. }\end{array}$ \\
\hline & & $\begin{array}{l}\text { Editor: Is this accurate? Could forensic investigations reveal root sources of some defects that could guide } \\
\text { improved early test and computational campaigns? }\end{array}$ \\
\hline \multirow[t]{2}{*}{ GT/CFD } & \multirow[t]{2}{*}{8} & $\begin{array}{l}\text { Even more than the tools, the people and processes need to be better understood and integrated with the } \\
\text { advanced computer hardware and software to increase the effectiveness of CSE in the aeronautical } \\
\text { development process. }\end{array}$ \\
\hline & & $\begin{array}{l}\text { Editor: Tools are inert objects without use. How tools are used are at the root of their development and } \\
\text { then must be used by qualified people using effective processes. }\end{array}$ \\
\hline \multirow[t]{2}{*}{ GT/CFD } & \multirow[t]{2}{*}{8} & $\begin{array}{l}\text { The aeronautics community would be better served putting their energy into creating a vision for how CSE } \\
\text { can be integrated with physical testing processes to increase the effectiveness of both during the } \\
\text { development of systems. Effectiveness in the context of this article means the ability to reduce the overall } \\
\text { cycle time for development while minimizing the need for rework of late defect discoveries. }\end{array}$ \\
\hline & & $\begin{array}{l}\text { Editor: Again, cycle time reduction by defect reduction; points to need for integrated development using } \\
\text { EFD and CFD. }\end{array}$ \\
\hline GT/CFD & 8 & $\begin{array}{l}\text { The need for robust } V \& V \text { also underscores the requirements to put error bars on the computational results } \\
\text { as well as the experimental results. However, one must exercise caution in doing so. A CSE solution, since } \\
\text { it is deterministic for a given computation, will have zero precision errors but could have excessive bias } \\
\text { errors driven by grid resolution, time steps, numerical dissipation, boundary conditions, and physics } \\
\text { modeling. On the other hand, experimental data can have both precision and bias errors. Precision errors } \\
\text { at the } 95 \% \text { confidence level are usually well documented in the experiment, but attention needs to be paid }\end{array}$ \\
\hline
\end{tabular}




\begin{tabular}{|c|c|c|}
\hline & \multirow[b]{3}{*}{8} & \multirow{2}{*}{$\begin{array}{l}\text { to bias errors driven by geometric modifications of a scaled model, Reynolds number scaling, wall } \\
\text { interference, support interference, etc. } \\
\text { Editor: Uncertainty analysis for CFD is required just as it's required for WT data. }\end{array}$} \\
\hline & & \\
\hline GT/CFD & & $\begin{array}{l}\text { The proper debate needs to be centered on how Computational Science and Engineering (CSE) and wind } \\
\text { tunnel testing can be integrated to reduce the overall cycle time for development of an aeronautical system. }\end{array}$ \\
\hline GT/CFD & 16 & $\begin{array}{l}\text { Elements of this more aggressive collaborative study could include: } \\
\text { - An integrated use of advanced computational fluid dynamics (CFD) codes, modern design of } \\
\text { experiments (MDOE), and "fly the mission" testing techniques to reduce the overall test hours in a } \\
\text { wind tunnel "campaign". } \\
\text { - A basic theoretical/experimental/computational study of scaling principles for vortex-dominated or } \\
\text { massively separated flows. } \\
\text { Concomitant with the high-alpha study above, the same collaborative effort could help develop a } \\
\text { database for validation of the next generation of CFD codes. }\end{array}$ \\
\hline GT/CFD & 17 & $\begin{array}{l}\text { Ground testing, flight testing, and modeling and simulation must continue to be fused into a routine by } \\
\text { addressing the evolution of analytical models, flexibility of the processes, and judicious consideration of } \\
\text { the data from previous tests and models. The systematic utilization of these information sources will allow } \\
\text { customers to benefit from a procedure that is seamless and easily used ... In order for this to occur, the } \\
\text { evolution of analytical models into flexible processes that enable the application of any of these models at } \\
\text { any point in the system development is needed. }\end{array}$ \\
\hline GT/CFD & 19 & $\begin{array}{l}\text { The comment is valid in that we need to use inexpensive (never cheap) data sources early-on when } \\
\text { tolerance for uncertainty is highest, then switch to more accurate data sources (and yes usually more } \\
\text { expensive) when tolerance for uncertainty is low. }\end{array}$ \\
\hline GT/CFD & 19 & EFD and CFD tools must be developed in tandem. \\
\hline GT/CFD & 19 & $\begin{array}{l}\text { Need CFD to extrapolate Reynolds number. We look for parallel measurements to compare EFD and CFD } \\
\text { in meaningful ways. For example, we extrapolate wakes, etc., to get comparisons. }\end{array}$ \\
\hline GT/CFD & 19 & Need to have effective coordination between EFD and CFD; common criteria are required. \\
\hline GT/CFD & 19 & $\begin{array}{l}\text { There is a lack of effective coordination between the EFD and CFD communities. There is stove-piping } \\
\text { and competition for funding. Need customer "pull" to develop capability; however, the customer doesn't } \\
\text { want to pay for it. }\end{array}$ \\
\hline Efficiency & 5 & $\begin{array}{l}\text { To shorten the aircraft and aerospace vehicle design cycle, enable efficient and economical study and } \\
\text { development of advanced, nontraditional design concepts, and reduce the costs associated with physical } \\
\text { testing/infrastructure, an aggressive research program in turbulence modeling and CFD algorithmic/ } \\
\text { numerical/hardware architecture issues, including experimental validation, is required. Specifically, } \\
\text { research needs to be conducted in the following areas: } \\
\text { - } \quad \text { Higher moment (e.g., second-order-closure) turbulence modeling. } \\
\text { - } \quad \text { Accurate wall modeling for LES. } \\
\text { - } \quad \text { Modeling of a continuous interface between RANS and LES. } \\
\text { - } \quad \text { High-order methods for low dissipation/dispersion schemes. } \\
\text { - } \quad \text { Fast, robust solver technology. } \\
\text { - } \quad \text { Output-based 3D viscous grid adaptation and error estimation. } \\
\text { - } \quad \text { Strategies for exploiting the potential of future computer hardware. } \\
\text { - } \quad \text { Carefully designed experiments to aid in the development of physical models and CFD validation. }\end{array}$ \\
\hline Efficiency & 8 & $\begin{array}{l}\text { The proper debate needs to be centered on how Computational Science and Engineering (CSE) and wind } \\
\text { tunnel testing can be integrated to reduce the overall cycle time for development of an aeronautical system. }\end{array}$ \\
\hline Efficiency & 19 & $\begin{array}{l}\text { Whether experimental or CFD, the concern is how long it takes to produce information for flight prediction; } \\
\text { need to produce knowledge, not data. Whether experimental or CFD, the developer must know his } \\
\text { customer's accuracy requirements which are becoming more stringent in many ways; e.g., cruise and } \\
\text { pitching moment considerations. }\end{array}$ \\
\hline Sustainment & 18 & Maintenance and improvement of key test assets is a vital component of enabling future test capabilities. \\
\hline Investment & 1 & $\begin{array}{l}\text { Hence, to fully implement CSE into the design and development of military flight systems will require the } \\
\text { government to create a monopsony (a single customer vs. a single supplier as in a monopoly). The } \\
\text { monopsony for design and development of flight systems will require: } \\
\text { - Government guidance on the systems engineering approach to design and development, fully } \\
\text { integrating testing and CSE. } \\
\text { - A common architecture for applied CSE, enabling optimization for large-scale computing, } \\
\text { multidisciplinary dynamic simulations, standard libraries, and databases for DoD systems, } \\
\text { A modular "plug and play" environment permitting OEMs to use their own proprietary CSE tools, but } \\
\text { in the common development process. } \\
\text { - A critical mass of government CSE applications experts to ensure development and sustainment of } \\
\text { the common architecture as well as to provide the government the ability to perform independent } \\
\text { assessment of OEM designs during the acquisition process. }\end{array}$ \\
\hline Investment & 1 & $\begin{array}{l}\text { The best way to minimize the impact of rework on cycle time is early discovery of defects. This will entail } \\
\text { improvements in design methodologies employed by aircraft companies coupled with improvements in } \\
\text { wind tunnel testing and modeling techniques. These latter improvements minimize any defects in design } \\
\text { being passed downstream to flight testing, where the cost of fixing the defect increases an order of } \\
\text { magnitude. Also, feedback loops from discrepancies found inflight testing back to ground testing and back } \\
\text { to design methodology need to be institutionalized to make further improvements. A primary target for } \\
\text { decreasing rework is improving the early determination of the impact of steady and unsteady flow effects }\end{array}$ \\
\hline
\end{tabular}




\begin{tabular}{|c|c|c|}
\hline & & $\begin{array}{l}\text { on the vehicle structure. Historically, most aircraft development programs have discovered } 10 \text { structural } \\
\text { flaws inflight with varying degrees of cost and schedule impacts that can reach a billion dollars and a year } \\
\text { to overcome. }\end{array}$ \\
\hline & & Editor: Investment and process and management and collaboration and integration of CFD/EFD \\
\hline \multirow[t]{2}{*}{ Investment } & \multirow[t]{2}{*}{5} & $\begin{array}{l}\text { An urgent need exists to reinvigorate research in computational science and engineering at NASA, as well } \\
\text { as to provide access to the state-of-the-art computer hardware to NASA scientists. The following broad } \\
\text { recommendations from a DoE study [Internal Reference] are also relevant to aeronautics MODSIM: } \\
\text { 1. "Major new investments in computational science are needed in all of the mission areas. .... Such } \\
\text { investments will extend the important scientific opportunities that have been obtained by a fusion of } \\
\text { sustained advances in scientific models, mathematical algorithms, computer architecture, and } \\
\text { scientific software engineering." } \\
\text { "Extensive investment in new computational facilities is strongly recommended, since simulation } \\
\text { now cost-effectively complements experimentation in the pursuit of the answers to numerous } \\
\text { scientific questions. New facilities should strike a balance between capability computing for those } \\
\text { "heroic simulations' that cannot be performed any other way, and capacity computing for 'production' } \\
\text { simulations that contribute to the steady stream of progress." } \\
\text { "Additional investments in hardware facilities and software infrastructure should be accompanied by } \\
\text { sustained collateral investments in algorithm research and theoretical development. Improvements } \\
\text { in basic theory and algorithms have contributed as much to increases in computational simulation } \\
\text { capability as improvements in hardware and software over the first six decades of scientific } \\
\text { computing." }\end{array}$ \\
\hline & & Editor: LaRC just built the Katherine Johnson computing facility. \\
\hline Investment & 5 & $\begin{array}{l}\text { Because the solution cost of high-order methods varies strongly with grid size, robust grid adaptation is } \\
\text { needed to optimally distribute the grid and minimize the overall grid size. Therefore, the success of high- } \\
\text { order-methods technology requires advancement in efficient solvers, as well as high-fidelity grid generation } \\
\text { and adaptation. }\end{array}$ \\
\hline Investment & 5 & $\begin{array}{l}\text { The challenges that are faced by CFD (e.g., unsteady separation, boundary-layer transition) are such that } \\
\text { they cannot be resolved by the mere availability of faster machines. Research is needed for the } \\
\text { development of more accurate numerical schemes, advanced solver technology, grid adaptation, error } \\
\text { estimation, physics modeling, and schemes for efficiently exploiting the capabilities of future massively } \\
\text { parallel machines. }\end{array}$ \\
\hline \multirow[t]{2}{*}{ Investment } & \multirow[t]{2}{*}{5} & $\begin{array}{l}\text { This may be the time to "cash in" the current aging infrastructure to build a test facility that is designed to } \\
\text { fully implement advances in computational science and engineering and advanced diagnostic tools. Such } \\
\text { a facility could be energy efficient and "green" as well. }\end{array}$ \\
\hline & & Editor: Huge challenge. CRV for NTF is $\$ 500 \mathrm{M}+$ \\
\hline \multirow[t]{2}{*}{ Investment } & \multirow[t]{2}{*}{5} & $\begin{array}{l}\text { To shorten the aircraft and aerospace vehicle design cycle, enable efficient and economical study and } \\
\text { development of advanced, nontraditional design concepts, and reduce the costs associated with physical } \\
\text { testing/infrastructure, an aggressive research program in turbulence modeling and CFD algorithmic/ } \\
\text { numerical/hardware architecture issues, including experimental validation, is required. Specifically, } \\
\text { research needs to be conducted in the following areas: } \\
\text { - Higher moment (e.g., second-order-closure) turbulence modeling. } \\
\text { - } \quad \text { Accurate wall modeling for LES. } \\
\text { - } \quad \text { Modeling of a continuous interface between RANS and LES. } \\
\text { - } \quad \text { High-order methods for low dissipation/dispersion schemes. } \\
\text { - } \quad \text { Output-based 3D viscous grid adaptation and error estimation. } \\
\text { - } \quad \text { Strategies for exploiting the potential of future computer hardware. } \\
\text { - } \quad \text { Carefully designed experiments to aid in the development of physical models and CFD validation. }\end{array}$ \\
\hline & & Editor: CFD \\
\hline \multirow[t]{2}{*}{ Investment } & \multirow[t]{2}{*}{8} & $\begin{array}{l}\text { The need for robust } V \& V \text { also underscores the requirements to put error bars on the computational results } \\
\text { as well as the experimental results. However, one must exercise caution in doing so. A CSE solution, since } \\
\text { it is deterministic for a given computation, will have zero precision errors but could have excessive bias } \\
\text { errors driven by grid resolution, time steps, numerical dissipation, boundary conditions, and physics } \\
\text { modeling. On the other hand, experimental data can have both precision and bias errors. Precision errors } \\
\text { at the } 95 \% \text { confidence level are usually well documented in the experiment, but attention needs to be paid } \\
\text { to bias errors driven by geometric modifications of a scaled model, Reynolds number scaling, wall } \\
\text { interference, support interference, etc. }\end{array}$ \\
\hline & & Editor: CFD quality \\
\hline Investment & $9 a$ & $\begin{array}{l}\text { The most readily identifiable major investment need from our survey of users is associated with the } \\
\text { hypersonic vehicle programs. Serious research challenges in hypersonic air-breathing propulsion (e.g., } \\
\text { vitiated/non-vitiated issues in hypersonic propulsion facilities) may require new facilities and test } \\
\text { approaches for breakthroughs to occur. }\end{array}$ \\
\hline Investment & 11 & A large static rig facility is needed for testing full-scale prototype rotorcraft systems. \\
\hline Investment & 11 & $\begin{array}{l}\text { An improved large-scale, low-speed capability (from the suite of existing subsonic wind tunnels), with } \\
\text { enhanced anechoic treatments and with greatly improved wind tunnel flow quality, is needed to meet future } \\
\text { acoustic test requirements. These facility modifications are critical to achieving goals for fuel efficiency, }\end{array}$ \\
\hline
\end{tabular}




\begin{tabular}{|c|c|c|}
\hline & & $\begin{array}{l}\text { noise reduction, and military rotorcraft mission capability. This shortfall exists in the near, mid, and far } \\
\text { terms. }\end{array}$ \\
\hline & & Editor: Some of this already (being) done at LaRC 14x22 \& GRC 9x15, NFAC \\
\hline Investment & 12 & $\begin{array}{l}\text { Modern infrastructure: high quality R\&D infrastructure as a fundamental pillar of efficient high-technology } \\
\text { research, ranging from wind tunnels to experimental aircraft. }\end{array}$ \\
\hline Investment & 18 & Maintenance and improvement of key test assets is a vital component of enabling future test capabilities. \\
\hline Investment & 18 & New high-speed test infrastructure is required to meet anticipated requirements for future systems. \\
\hline Investment & 19 & $\begin{array}{l}\text { A large-scale (16-ft square test section) (AEDC/16S) supersonic wind tunnel testing capability is needed } \\
\text { for the development of expanded missile defense vehicles. }\end{array}$ \\
\hline \multirow[t]{2}{*}{ Workforce } & \multirow[t]{2}{*}{$9 a$} & Mothballing incurs the loss of important workforce expertise and knowledge. \\
\hline & & Editor: Workforce (and capability) is lost; it's very difficult to reconstitute if the facility is reactivated. \\
\hline Workforce & 12 & A skilled workforce: possessing the quality, skills and motivation to meet the challenges of the future. \\
\hline Workforce & 16 & New technical paraprofessional, scientists and engineers, career ladder within the contractor workforce. \\
\hline Workforce & 16 & $\begin{array}{l}\text { Efforts should be undertaken by the Air Force T\&E Enterprise to share information on its technical } \\
\text { excellence initiatives with the larger, national T\&E and acquisition workforces. }\end{array}$ \\
\hline Workforce & 18 & Development of a knowledgeable test workforce is critical for the national infrastructure. \\
\hline Workforce & 19 & Need "data reductionists" and to design software to handle data. \\
\hline Strategic & 1 & $\begin{array}{l}\text {... a concept of operations and the necessary computing capacity needs to be developed to support the } \\
\text { aeronautical systems engineering process. }\end{array}$ \\
\hline Strategic & 1 & $\begin{array}{l}\text { The proper national debate that needs to be held is not CSE versus test facilities. The aeronautics } \\
\text { community would be better served putting their energy into creating a vision for how CSE can be integrated } \\
\text { with physical testing processes to increase the effectiveness of both during the development of systems. . } \\
\text {. The elements that need to be advanced to re-engineer the aeronautical development process include } \\
\text { CSE as well as test facilities. In addition, a vision needs to be created for innovative ways to bring CSE } \\
\text { and testing together to have the maximum impact on the effectiveness of the development process. }\end{array}$ \\
\hline \multirow[t]{2}{*}{ Strategic } & \multirow[t]{2}{*}{1} & $\begin{array}{l}\text { CSE alone will not provide maximum impact to cycle time reduction but must be integrated with other tools } \\
\text { such as design of experiments, streamlined test methodologies, advanced diagnostic tools, networking, } \\
\text { and knowledge management. }\end{array}$ \\
\hline & & $\begin{array}{l}\text { Editor: Must be a sustained investment in integrated CSE and EFD to achieve gains in cycle time reduction } \\
\text { with equal or better results. }\end{array}$ \\
\hline Strategic & 6 & $\begin{array}{l}\text { NASA should develop, foster, and leverage improved collaborations with key research partners and } \\
\text { industrial stakeholders across disciplines within the broader scientific and engineering communities. } \\
\text { - Leverage other government agencies and stakeholders (US and foreign) outside of the aerospace } \\
\text { field. } \\
\text { Improve collaboration with industry. }\end{array}$ \\
\hline \multirow[t]{2}{*}{ Strategic } & \multirow[t]{2}{*}{6} & $\begin{array}{l}\text { NASA should lead efforts to develop and execute integrated experimental testing and computational } \\
\text { validation campaigns. }\end{array}$ \\
\hline & & Editor: If not NASA, who? \\
\hline Strategic & 7 & $\begin{array}{l}\text { Enable and incentivize a much shorter time to market from initial research to commercialization assisted } \\
\text { by an integrated, research and innovation friendly environment. }\end{array}$ \\
\hline Strategic & 8 & $\begin{array}{l}\text { The aeronautics community would be better served putting their energy into creating a vision for how CSE } \\
\text { can be integrated with physical testing processes to increase the effectiveness of both during the } \\
\text { development of systems. Effectiveness in the context of this article means the ability to reduce the overall } \\
\text { cycle time for development while minimizing the need for rework of late defect discoveries. }\end{array}$ \\
\hline Strategic & 8 & $\begin{array}{l}\text { There is also the potential for sharing some of the same modeling methodologies between the structural } \\
\text { analysts and the propulsion system designers. The fluid-structure interactions that drive structural design } \\
\text { exhibit the same fundamental physics as the fluid-structure interactions on the aeromechanics of fan and } \\
\text { compressor blades. }\end{array}$ \\
\hline \multirow[t]{2}{*}{ Strategic } & \multirow[t]{2}{*}{$9 a$} & $\begin{array}{l}\text { NASA should work with the DoD to analyze the viability of a national reliance test facility plan, since this } \\
\text { could affect the determination of the future minimum set of facilities NASA must continue to support. }\end{array}$ \\
\hline & & Editor: Isn't this what NPAT (National Partnership for Aeronautical Testing) is for? \\
\hline \multirow[t]{2}{*}{ Strategic } & \multirow[t]{2}{*}{$9 a$} & $\begin{array}{l}\text { The most critical issue is for NASA headquarters leadership to develop a specific and clearly understood } \\
\text { aeronautics test technology vision and plan. }\end{array}$ \\
\hline & & Editor: Leadership? \\
\hline \multirow[t]{2}{*}{ Strategic } & \multirow[t]{2}{*}{$9 a$} & $\begin{array}{l}\text { When redundancy is eliminated, utilization reflects management challenges to keep low-use facilities } \\
\text { healthy for future needs, given low revenues from testing rather than a metric of the number of facilities of } \\
\text { each type that the country needs. }\end{array}$ \\
\hline & & Editor: Leadership? Rewards are based on near-term results. \\
\hline Strategic & $9 \mathrm{~b}$ & $\begin{array}{l}\text { NASA's Aeronautics Test Facility Capabilities Remain Important for National Strategic Needs } \\
\text { - These capabilities continue to be strategically important to aeronautics research, defense, } \\
\text { commercial, and space sectors. }\end{array}$ \\
\hline Strategic & 11 & $\begin{array}{l}\text { Interdependencies and overlapping research goals among research agencies in the Federal Government } \\
\text { create a need for closer cooperation and coordination of processes and facilities planning. Some of the } \\
\text { barriers to improved cooperation can be lowered by leadership from the Federal departments and agencies } \\
\text { that own critical infrastructure, the NSTC and the Office of Management and Budget (OMB). There are a }\end{array}$ \\
\hline
\end{tabular}




\begin{tabular}{|c|c|c|}
\hline & \multirow[b]{3}{*}{12} & $\begin{array}{l}\text { number of existing bilateral collaborations on planning and coordination of aeronautics RDT\&E } \\
\text { infrastructure, and these efforts should be continued and expanded. }\end{array}$ \\
\hline & & Editor: Leadership and collaboration so all organizations benefit. \\
\hline Strategic & & $\begin{array}{l}\text { The following enablers are needed to achieve the goals: } \\
\text { - Optimization of the research and innovation lifecycle: encompassing the full European aviation } \\
\text { sector, defining research roadmaps which cover all the successive steps of the innovation cycle. }\end{array}$ \\
\hline \multirow[t]{2}{*}{ Strategic } & \multirow[t]{2}{*}{16} & To protect national interests it is imperative that NASA and DoD cooperate both boldly and broadly. \\
\hline & & Editor: Isn't this what NPAT is for? \\
\hline Strategic & 16 & $\begin{array}{l}\text { Elements of this more aggressive collaborative study could include: } \\
\text { - An integrated use of advanced computational fluid dynamics (CFD) codes, modern design of } \\
\text { experiments (MDOE), and "fly the mission" testing techniques to reduce the overall test hours in a } \\
\text { wind tunnel "campaign". } \\
\text { A basic theoretical/experimental/computational study of scaling principles for vortex-dominated or } \\
\text { massively separated flows. } \\
\text { - Concomitant with the high-alpha study above, the same collaborative effort could help develop a } \\
\text { database for validation of the next generation of CFD codes. }\end{array}$ \\
\hline \multirow[t]{2}{*}{ Strategic } & \multirow[t]{2}{*}{18} & $\begin{array}{l}\text { Divestment of redundant and nonessential test infrastructure is required to focus limited resources on } \\
\text { critical capabilities and new infrastructure requirements. }\end{array}$ \\
\hline & & $\begin{array}{l}\text { Editor: Tunnel huggers don't like giving up anything! The nation has lost a lot of test infrastructure over the } \\
\text { last } 25 \text { years; often due to local situations. Was what was needed for the future retained? Suggest a formal } \\
\text { view on what is needed and take actions to support and invest in the future. Unneeded facilities are } \\
\text { monuments. }\end{array}$ \\
\hline Strategic & 18 & $\begin{array}{l}\text { This paper describes what the ideal future would look like: } \\
\text { "The most ideal future scenario will include highly integrated computational and physical simulation } \\
\text { capable of rapid evaluation of concepts and configurations. Robust and reliable CFD modeling simulation } \\
\text { will be used to evaluate and narrow the design options to a chosen few. Rapid wind tunnel model design } \\
\text { and fabrication would begin taking advantage of light-weight, easily workable, and high-strength materials } \\
\text { to manufacture modularized model parts for testing. Wind tunnels would be readily available with } \\
\text { capabilities spanning a large speed range and flow visualization at any speed, efficient data gathering } \\
\text { process (hardware and software), automation that reduces model changes, and adaptable to various types } \\
\text { of testing, i.e., aero, propulsion, loads, and noise. Entries in the tunnel will be shorter and more rapid, } \\
\text { providing focused physical validation of analytic estimates and, where appropriate, volumes of data } \\
\text { required for extensive control law and flight envelope expansion." }\end{array}$ \\
\hline \multirow[t]{2}{*}{ Strategic } & \multirow[t]{2}{*}{19} & EFD and CFD tools must be developed in tandem. \\
\hline & & Editor: With a defined set of guidelines/requirements \\
\hline Strategic & 19 & $\begin{array}{l}\text { Need capabilities for both computationalists and aerodynamicists to understand each step of the process; } \\
\text { must not expect each participant to understand every detail of developing the information. }\end{array}$ \\
\hline \multirow[t]{2}{*}{ Strategic } & \multirow[t]{2}{*}{19} & $\begin{array}{l}\text { Need to have people from both worlds (experimental and theory) available to the aerodynamicist. We } \\
\text { obtain much data from experiments, and orders of magnitude more from CFD. }\end{array}$ \\
\hline & & Editor: ... orders of magnitude more from CFD??? Only at a specific point. \\
\hline \multirow[t]{2}{*}{ Strategic } & \multirow[t]{2}{*}{19} & $\begin{array}{l}\text { The value of wind tunnels for weapon systems should be measured by the quality of flight systems we can } \\
\text { produce rather than cost. } \\
\text { - For example, testing the interaction of fins and jets requires large-scale supersonic capability. This is } \\
\text { why the inactivation of } 16 \mathrm{~S} \text { has been a big loss to the missile community. } \\
\text { In making this statement, we need to make sure we can communicate in what ways the missile } \\
\text { community has suffered loss. This is not apparent to the decision makers and the case for the high } \\
\text { cost of reactivation and sustainment has not been made yet. }\end{array}$ \\
\hline & & Editor: Treat capabilities as tools, with value based on contributions to product. \\
\hline \multirow[t]{2}{*}{ Strategic } & \multirow[t]{2}{*}{19} & $\begin{array}{l}\text { We should use what dollars we have to make what we have a little better. We need a program or a clear } \\
\text { direction to go to tell us what facility capabilities we need to invest in. }\end{array}$ \\
\hline & & Editor: Leadership! \\
\hline Programmatic & 2 & $\begin{array}{l}\text { NASA aeronautics should aggressively pursue collaboration with the Department of Defense, the Federal } \\
\text { Aviation Administration, the U.S. aerospace industry, and international aeronautics research agencies. } \\
\text { NASA should adopt management practices to facilitate effective collaboration and treat external } \\
\text { organizations as customers and partners. }\end{array}$ \\
\hline Programmatic & 2 & $\begin{array}{l}\text { NASA aeronautics should become the nation's repository of flight research data and flight test results and } \\
\text { should make these archival data readily accessible to key stakeholders-the engineers and scientists in } \\
\text { industry, academia, and other government agencies. }\end{array}$ \\
\hline Programmatic & 3 & $\begin{array}{l}\text { Sufficient equipment and support services needed to conduct high-quality fundamental research should } \\
\text { be provided to NASA's research community. }\end{array}$ \\
\hline \multirow[t]{2}{*}{ Programmatic } & \multirow[t]{2}{*}{3} & $\begin{array}{l}\text { NASA should find a solution to its deferred maintenance issues before catastrophic failures occur that will } \\
\text { seriously impact missions and research operations. . . To optimize limited maintenance resources, NASA } \\
\text { should implement predictive-equipment-failure processes, often known as health monitoring, currently } \\
\text { used by many organizations. }\end{array}$ \\
\hline & & $\begin{array}{l}\text { Editor: Some improvement since this was written; much of the progress was accomplished by } \\
\text { implementing the second input, making some hard decisions on levels of support and moving to a more }\end{array}$ \\
\hline
\end{tabular}




\begin{tabular}{|c|c|c|}
\hline & & $\begin{array}{l}\text { proactive condition based maintenance using improved health monitoring techniques. However, a large } \\
\text { maintenance backlog remains. }\end{array}$ \\
\hline Programmatic & 6 & $\begin{array}{l}\text { NASA should lead efforts to develop and execute integrated experimental testing and computational } \\
\text { validation campaigns. }\end{array}$ \\
\hline \multirow[t]{2}{*}{ Programmatic } & $9 a$ & $\begin{array}{l}\text { NASA should manage its portfolio to keep its minimum-set WT/PT facilities healthy and open for business. } \\
\text { Most importantly, for those facilities in most financial danger, NASA should identify financial shared support } \\
\text { to keep them from entering financial collapse because of variable utilization, FCR accounting, and lack of } \\
\text { program support for long-term national benefits. }\end{array}$ \\
\hline & & Editor: Management and leadership - AETC is tasked with doing this for key capabilities with NASA. \\
\hline \multirow[t]{2}{*}{ Programmatic } & $9 a$ & $\begin{array}{l}\text { NASA should use shared funding of annual full costs to set transfer prices. This approach allows centers } \\
\text { and users to split budgetary burden. }\end{array}$ \\
\hline & & Editor: Cost management \\
\hline \multirow[t]{2}{*}{ Programmatic } & $9 a$ & $\begin{array}{l}\text { The most critical issue is for NASA headquarters leadership to develop a specific and clearly understood } \\
\text { aeronautics test technology vision and plan, to continue to support the development of plans to very } \\
\text { selectively consolidate and broadly modernize existing test facilities, and to proscribe common } \\
\text { management and accounting directions for NASA's WT/PT facilities. }\end{array}$ \\
\hline & & Editor: Maybe "leadership"? More likely vision, perhaps "collaborative vision"; who does this and how? \\
\hline Programmatic & $9 a$ & $\begin{array}{l}\text { When redundancy is eliminated, utilization reflects management challenges to keep low-use facilities } \\
\text { healthy for future needs, given low revenues from testing rather than a metric of the number of facilities of } \\
\text { each type that the country needs. }\end{array}$ \\
\hline Programmatic & 19 & $\begin{array}{l}\text { The value of wind tunnels for weapon systems should be measured by the quality of flight systems we can } \\
\text { produce rather than cost. }\end{array}$ \\
\hline Programmatic & 19 & $\begin{array}{l}\text { We should use what dollars we have to make what we have a little better. We need a program or a clear } \\
\text { direction to go to tell us what facility capabilities we need to invest in. }\end{array}$ \\
\hline $\begin{array}{l}\text { Systems } \\
\text { Integration }\end{array}$ & 1 & $\begin{array}{l}\text {. . feedback loops from discrepancies found inflight testing back to ground testing and back to design } \\
\text { methodology need to be institutionalized to make further improvements. A primary target for decreasing } \\
\text { rework is improving the early determination of the impact of steady and unsteady flow effects on the vehicle } \\
\text { structure. Historically, most aircraft development programs have discovered } 10 \text { structural flaws inflight with } \\
\text { varying degrees of cost and schedule impacts that can reach a billion dollars and a year to overcome. }\end{array}$ \\
\hline \multirow[t]{2}{*}{$\begin{array}{l}\text { Systems } \\
\text { Integration }\end{array}$} & 8 & $\begin{array}{l}\text { There is also the potential for sharing some of the same modeling methodologies between the structural } \\
\text { analysts and the propulsion system designers. The fluid-structure interactions that drive structural design } \\
\text { exhibit the same fundamental physics as the fluid-structure interactions on the aeromechanics of fan and } \\
\text { compressor blades. }\end{array}$ \\
\hline & & \\
\hline
\end{tabular}




\section{Acknowledgments}

The editors wish to recognize and thank the many people, members of the GTTC and a number of nonmembers, for helping with this effort - participating in conference meetings, telecoms, reviewing source material, and reviewing and improving this paper. Specific thanks are due to Michael Mills, Paul Kelly, Timothy Wadhams, Stephen Ryle, Joe Patrick, Paul Piscopo, Steven Bauer, and Eric Walker for reviewing the paper draft and making inputs that resulted in significant improvement. From the many meetings and discussion, it is clear that these many people invested their time because they care about the future of aerospace and recognize its importance to the United States and to the world.

\section{Disclaimer of Endorsement}

Neither the U.S. Government nor NASA endorse or recommend any commercial products, processes, or services. Reference to or appearance of any specific commercial products, processes, or services by trade name, trademark, manufacturer, or otherwise, in NASA materials does not constitute or imply its endorsement, recommendation, or favoring by the U.S. Government or NASA and are presented for reporting purposes only.

The views and opinions of the author(s) expressed in this report do not necessarily state or reflect those of the U.S. Government, NASA, Aero Systems Engineering, Inc., and/or Jacobs and they may not be used for advertising or product endorsement purposes. 


\section{References}

1. Slotnik, J., Khodadoust, A., Alonso, J., Darmofal, D., Gropp, W., Lurie, E., and Mavriplis, D., “CFD Vision 2030 Study: A Path to Revolutionary Computational Aerosciences", NASA/CR-2014-218178, March 2014.

2. Anderson, J. D., "The Airplane: A History of Its Technology", 2002.

3. American Association for the Advancement of Science, "Definitions of Key Terms", http://www.aaas.org/page/definitionskey-terms, May 23, 2016

4. American Association for the Advancement of Science, "Historical Trends in Federal R\&D", http://www.aaas.org/page/historical-trends-federal-rd, May 23, 2016.

5. Kraft, E. M., "Integrating Computational Science and Engineering with Testing to Re-Engineer the Aeronautical Development Process", 48th AIAA Aerospace Sciences Meeting Including the New Horizons Forum and Aerospace Exposition. January 2010, AIAA 2010-139.

6. Committee to Assess NASA's Aeronautics Flight Research Capabilities, National Research Council of the National Academies, "Recapturing NASA's Aeronautics Flight Research Capabilities", The National Academies Press, 2010.

7. Committee on the Assessment of NASA's Laboratory Capabilities, National Research Council of the National Academies, "Capabilities for the Future: An Assessment of NASA Laboratories for Basic Research", The National Academies Press, 2010.

8. Kallimani, J., Ohlandt, C., Anton, P. and Osburg, J, "Future Test Needs of U.S. National Wind Tunnels for NASA's Aeronautics Test Program: An Approach for Mapping Ground Test Facility Usage Projections into Capability Projections", 49th AIAA Aerospace Sciences Meeting including the New Horizons Forum and Aerospace Exposition. January 2011, AIAA 2011-1069.

9. Malik, M., and Bushnell, D., "Role of Computational Fluid Dynamics and Wind Tunnels in Aeronautics R and D", NASA/TP2012-217602, November 2012.

10. European Commission, "Flightpath 2050, Europe's Vision for Aviation”, Luxembourg: Publications Office of the European Union, 2011.

11. Kraft, E. M., “After 40 Years Why Hasn't the Computer Replaced the Wind Tunnel?”, ITEA Journal, 2010, 31: 329-346.

12. Anton, P. S, Johnson, D. J., Block, M., Brown, M., Drezner, J., Dryden, J., Gritton, E. C., Hamilton, T., Hogan, T., Mesic, R., Peetz, D., Raman, R., Steinberg, P., Strong, J., and Trimble, W., "Wind Tunnel and Propulsion Test Facilities", Rand Corporation, 2004.

13. Anton, P. S, Raman, R., Osburg, J., and Kallimani, J. G., “An Update of the Nation's Long-Term Strategic Needs for NASA's Aeronautics Test Facilities", Rand Corporation, 2009.

14. The National Science and Technology Council, "National Aeronautics Research and Development Plan", Office of Science and Technology Policy, Washington, D.C., February, 2010.

15. The National Science and Technology Council, "National Aeronautics Research, Development, Test, and Evaluation (RDT\&E) Infrastructure Plan”, Office of Science and Technology Policy, Washington, D.C., January, 2011.

16. Advisory Council for Aviation Research and Innovation in Europe, "Realising Europe's Vision for Aviation, Strategic Research and Innovation Agenda, Volume 1", September, 2012.

17. Kraft, E. M., "HPCMP CREATETM-AV and the Air Force Digital Thread", 53rd AIAA Aerospace Sciences Meeting. January 2015, AIAA 2015-0042.

18. Fetterhoff, T., Kraft, E., Laster, M., and Cockson, W., "High-Speed/Hypersonic Test and Evaluation Infrastructure Capabilities Study", 14th AIAA/AHI Space Planes and Hypersonic Systems and Technologies Conference. November 2006, AIAA 2006-8043.

19. Melanson, M., "An Assessment of the Increase in Wind Tunnel Testing Requirements for Airvehicle Development Over the last 50 Years", 46th AIAA Aerospace Sciences Meeting and Exhibit. January 2008, AIAA 2008-830.

20. Best, J., Kraft, E., and Huber, A., "Revitalizing the Technical Excellence of the Workforce at the Arnold Engineering Development Center (AEDC) and Beyond”, 2008 U.S. Air Force T\&E Days. February 2008, AIAA 2008-1611.

21. Skelley, M., Langham, T., and Peters, W., "Integrated Test and Evaluation for the 21 st Century", USAF Developmental Test and Evaluation Summit. November, 2004, AIAA 2004-6873.

22. Melanson, M., Chang, M., and Baker II, W., "Wind Tunnel Testing's Future: A Vision of the Next Generation of Wind Tunnel Test Requirements and Facilities", 48th AIAA Aerospace Sciences Meeting Including the New Horizons Forum and Aerospace Exposition. January 2010, AIAA 2010-142.

23. Dunn, S. C., "Direction and Integration of EFD and CFD, a Summary of Two Panel Sessions," 54th AIAA Aerospace Sciences Meeting, January 2016, AIAA 2016-0896.

24. American Institute of Aeronautics and Astronautics, Computational Fluid Dynamics Technical Committee, "Guide for the Verification and Validation of Computational Fluid Dynamics Simulations", AIAA G-077-1998, 2002.

25. Morgan, D., "NASA Appropriations and Authorizations: A Fact Sheet", Congressional Research Service, September 11, 2017.

26. "Propulsion Systems Laboratory", page last updated August 14, 2017, retrieved from https://www1.grc.nasa.gov/facilities/psl/. 
27. Mills, M. L., "Feasibility of Operating the AEDC Supersonic Wind Tunnel (16S) Up to Mach Number 6", AIAA 2004-1138, 2004. 